\title{
Ethnomedicinal Plants of India with Special Reference to an Indo-Burma Hotspot Region: An overview
}

\author{
Prabhat Kumar Rai and H. Lalramnghinglova
}

\section{Research}

\begin{abstract}
Ethnomedicines are widely used across India. Scientific knowledge of these uses varies with some regions, such as the North Eastern India region, being less well known. Plants being used are increasingly threatened by a variety of pressures and are being categories for conservation management purposes. Mizoram state in North East India has served as the location of our studies of ethnomedicines and their conservation status. 302 plants from 96 families were recorded as being used by the indigenous Mizo (and other tribal communities) over the last ten years. Analysis of distributions of species across plant families revealed both positive and negative correlations that are interpretted as evidence of consistent bases for selection.
\end{abstract}

\section{Introduction}

Biodiversity has been specifically investigated in the context of designing efficient programs of monitoring and setting out conservation priorities (Balmford \& Long 1995, Gadgil 1996, Heywood 1995, Howard et al. 1998, Myers 1988, Myers et al. 2000, Negi \& Gadgil 2002, Oliver \& Beattie 1993, Pollard \& Yates 1993, Swengel \& Swengel 1999). The Global Biodiversity Assessment (Heywood 1995) requires a detailed knowledge of species distribution in particular landscapes. India's Biological Diversity Act 2002 aims to promote conservation, sustainable use and equitable sharing of benefits of India's biodiversity resources. In this context, traditional ecological knowledge (TEK) and its implication in the field of ethnobiology is of special focus in view of its deteriorating scenario due to the diverse environmental perturbations. Specific emphasis should be given to ethnomedicinal plants while setting priorities for biodiversity conservation in India (Sastry \& Chatterjee 2000).

\section{Global Relevance}

Knowledge of useful plants must have been the first acquired by man to satisfy his hunger, heal his wounds and treat various ailments (Kshirsagar \& Singh 2001, Schultes 1967). Traditional healers employ methods based on the ecological, socio-cultural and religious background of their people to provide health care (Anyinam 1995, Gesler 1992, Good 1980). Therefore, practice of ethnomedicine is an important vehicle for understanding indigenous societies and their relationships with nature (Anyinam 1995, Rai \& Lalramnghinglova 2010a).

Globally, plant diversity has offered biomedicine a broad range of medicinal and pharmaceutical products. Traditional medical practices are an important part of the primary healthcare system in the developing world (Fairbairn 1980, Sheldon et al. 1997, Zaidi \& Crow 2005.). In developed industrialized countries today, about $25 \%$ of drug prescriptions come from natural products while another $25 \%$ are from substances derived from modification of a

\section{Correspondence}

Prabhat Kumar Rai, Department of Environmental Sciences School of Earth Sciences and Natural Resource Management, Mizoram University, Tanhril, Aizawl 796009, INDIA. prabhatrai24@gmail.com

H. Lalramnghinglova, Department of Environmental Sciences School of Earth Sciences and Natural Resource Management, Mizoram University, Tanhril, Aizawl 796009, INDIA.

Ethnobotany Research \& Applications 9:379-420 (2011)

Published: December 14, 2011 
natural product (Anyinam 1995). According to an estimate of the WHO, approx. $88 \%$ of people in developing countries rely chiefly on traditional medicines (mostly plant extracts) for their primary health care needs (Anyinam 1995, Azaizeh et al. 2003, Farnsworth et al. 1985, Rai \& Lalramnghinglova 2010a, WHO 1995). In China, where there is one of the most sophisticated and extensive medical traditions, more than 5000 plants have been catalogued and 1700 of them are in common uses (Anyinam 1995). In India, at least 2500 plants, out of 18,000 recorded in the country are utilized for medicinal purposes (Anyinam 1995). There are about 46,000 licensed pharmacies manufacturing traditional remedies of Indian systems of medicine and homeopathy (Alok 1991, Anyinam 1995). Probably the region that makes the widest use of herbal preparations is Africa where people reputedly depend on plants, via ethnomedicine, for as much as $95 \%$ of their drug needs (Anyinam 1995, Iwu 1993).

Reyes-Garcia et al. (2008) used data collected among adult males in a society of farmers and foragers in the Bolivian Amazon, the 'Tsimane', for sixteen years. They empirically analyzed quantitative information on indigenous knowledge and uses of medicinal plants. Macías et al. (2007) in their review covered concerns regarding new theories addressing the role of secondary metabolites from an ecological point of view (i.e., co-evolution of plants and their potential enemies), chemical plant defence, adaptative strategies of phytophagues to plant toxins, and models and theories for carbon and nitrogen allocation.

All humans across the globe are somehow dependent on plants in order to meet various requirements for survival (Kala et al. 2004, Phillips \& Meilleur 1998). The use of medicinal plants by people in developing countries like India is popular because these products are considered safe, widely available at low cost and easy to access.

Unfortunately, recent decades have seen significant changes occurring within several aspects of ethnomedicine as a result of environmental degradation and tremendous changes in modern, social, and economic systems (Anyinam 1995, Rai \& Lalramnghinglova 2010a). Therefore, the present paper provides an overview on multifaceted aspects of ethnomedicinal plants in India with special reference to our research findings in Mizoram.

\section{Phytochemistry of Ethnomedicinal Plants: Implications in diverse diseases}

Curculigo orchioides Gaertn. contains flavonone glycoside-I (a powerful uterine-stimulant). It has been used along with other plants viz., Asparagus adscendens Roxb., Asparagus racemosus Willd., Chlorophytum borivilianum Santapau \& R.R. Fern. and Withania somnifera (L.) Dunal in several pharmaceutical formulations in In- dian systems of medicine as a metabolic enhancer and aphrodisiac (Ramawat et al. 1997, Suri et al. 1999).

Neurological disorders intimately linked with heart diseases are increasing. Mukherjee et al. (2001) has illustrated bioactive potential of some Hypericum species of India in relation to Central Nervous System (CNS) disorders. For example, $H$. hookerianum Wight \& Arn. and $H$. patulum Thunb., are reported to have effects on the CNS in animal models (Mukherjee et al. 2001). Kumar (2006) provided a very specific review of medicinal plants for CNS disorders and focused on a set of plant species considered to the most important: Ginkgo biloba L., Hypericum perfoliatum L., Piper methysticum G. Forst., Valeriana officinalis L., Bacopa monnieri (L.) Wettst., and Convolvulus pluricaulis Choisy.

In the current scenario of ever increasing human stress, ethnomedicinal plants having antioxidant properties are thought to be extremely fruitful. Many Indian plants have been investigated for their beneficial use as antioxidants or source of antioxidants using presently available experimental techniques (Ali et al. 2008). Asparagus racemosus is mainly known for its phytoestrogenic properties. With an increasing realization that hormone replacement therapy with synthetic estrogens is neither as safe nor as effective as previously envisaged, the interest in plant-derived estrogens has increased tremendously making $A$. racemosus particularly important (Bopana \& Saxena 2007). In Ayurveda, $A$. racemosus has been described as a rasayana herb and has been used extensively as an adaptogen to increase the non-specific resistance of organisms against a variety of stresses. Besides use in the treatment of diarrhoea and dysentery, the plant also has potent antioxidant, immunostimulant, anti-dyspepsia and antitussive effects. Bopana and Saxena (2007) evaluated the biological activities, pharmacological applications and clinical studies of $A$. racemosus in their critical review.

Members of Amaranthaceae are good natural sources of carotenoids, vitamin $\mathrm{C}$, nutritionally critical lysine, methionine and proteins (Ali et al. 2008, Bhatia \& Jain 2003). Kumaran \& Karunakaran (2007) used antioxidant assays such as total antioxidant activity, free radical scavenging, superoxide anion radical scavenging, hydrogen peroxide scavenging, nitric oxide scavenging, reducing power and metal ion chelating activities to illustrate the biological activity of Phyllanthus species. The antioxidant property of Phyllanthus debilis Klein ex Willd. can be attributed to the presence of phenolic compounds, flavonoids and flavonols (Ali et al. 2008, Kumaran \& Karunakaran 2007).

Apart from the aforesaid applications, ethnomedicinal plants may be considered for treatment of the infections frequently associated with certain dreaded diseases such as HIVIAIDS. For example, Sawangjaroen et al. (2005, 2006) evaluated the in-vitro activity of selected medicinal plants used in a primary health care project by AIDS pa- 


\section{Rai \& Lalramnghinglova - Ethnomedicinal Plants of India with Special Reference to an Indo-Burma Hotspot Region: An overview}

tients in southern Thailand against Entamoeba histolytica Schaudinn, 1903 and Giardia intestinalis (Lambl, 1859) Kofoid \& Christiansen, 1915.

Asia is an important global center for ancient written traditions of knowledge regarding use of plant species for treatment of various diseases. Examples include Ayurve$\mathrm{da}$, Unani and Chinese systems of medical care (Kala et al. 2004). Perry with Metzger (1980), Burkhill (1935) and others describe the medicinal plants of Asia (Houghton 2007).

\section{Prospects of Ethno-medicinal Plants: An Indian Scenario}

In India, the traditional folklore healthcare system has a long history and is very deeply rooted in rural and tribal populations. India has medicinal plants distributed in different geographical and environmental conditions (Chandler et al. 1979, Katewa 2009). India includes elements of three biodiversity hotspots (Himalay, Western Ghats, and Indo-Burma)that are highly endangered ecoregions (Myers et al. 2000, Sajem et al. 2008). The number of plant species in India is estimated to be over 45,000 representing about $7 \%$ of the world's flora (Ali et al. 2008, www.inheritanceindia.co.in) however, it covers only $2 \%$ of the earth's surface. India is one of the richest countries in the world in relation to genetic resources of medicinal and aromatic plants (Ali et al. 2008) with $11 \%$ of the total known plants having medicinal properties (Ali et al. 2008). Of the 20,000 angiosperm species in India, approximately 3,000 are used medicinally (Agarwal 1997, Rajendran et al. 2004).

An estimated $65 \%$ of the population in rural areas in India use the Ayurveda medicine system and medicinal plants to help meet their primary health care needs (Farnsworth et al. 1985, Pattanaik \& Reddy 2008, WHO 1992).

India has the second largest tribal population in the world after Africa (Jagtap et al. 2006). Many tribal communities in India still practice use of their traditional knowledge to treat a variety of diseases and ailments. Because these are considered to be safe, effective and inexpensive, indigenous remedies are gaining popularity among the people of both the urban and rural areas, especially in India and China (Katewa et al. 2004). (Together these countries comprise $50 \%$ of the global population.) Plants and their parts are not only used as food and medicine but also used in various tribal rituals that are a part of their social and religious life. Hence, the age-old knowledge of plants is the basis for ethnobotanical research in India (Jagtap et al. 2006).

This plant-based traditional knowledge has become a recognized tool in the search for new sources of drugs and nutraceuticals (Sharma \& Mujumdar 2003). There are a few surveys that reveal the practice of herbal medicine by the Korkus (Bhogaonkar \& Devarkar 2002a,b, Padhye et al. 1991, 1992) and other tribes of Melghat area (Chaudhari \& Hutke 2002). Review of literature revealed that few reports on the ethnopharmacognostic studies and the use of some plants for antisterility and urogenital disorders are available (Bhogaonkar \& Devarkar 2002a,b). Examination of aqueous residues of 16 ethnomedicinal plants (Samy et al. 1999) showed that Azadirachta indica A. Juss., Pongamia pinnata (L.) Merr., and Aloe barbadensis Mill. had maximum antibacterial activity. Coleus amboinicus Lour. and Calotropis procera (Aiton) W.T. Aiton were found to have high antioxidant activity of $91.64 \%$ and $88.72 \%$ respectively (Muthuvelan \& Raja 2008). Hexane, chloroform, ethyl acetate, methanol and water extracts from the flower of Cassia fistula L. were tested against bacteria and fungi. All the extracts exhibited antibacterial activity against Gram-positive organisms with minimum inhibitory concentrations (MIC) between 0.078 and $2.5 \mathrm{mg} / \mathrm{ml}$ (Duraipandiyan \& Ignacimuthu 2007 ).

When acetone, chloroform, ethyl acetate, hexane and methanol leaf extracts of Acalypha indica L., Achyranthes aspera L., Leucas aspera (Willd.) Link, Morinda tinctoria Noronha and Ocimum sanctum L. were studied against the early fourth-instar larvae of Aedes aegypti L., 1762 and Culex quinquefasciatus Say, 1823 all extracts showed moderate larvicidal effects. However, the highest larval mortality was found in the ethyl acetate extract of $A$. aspera (Bagavan et al. 2008). Highest larval (early fourth-instar larvae) of $C$. quinquefasciatus mortality was found in bark acetone extract of Ficus racemosa L. (Rahuman et al. 2008). They suggested that gluanol acetate that was present is a quite potent new mosquito larvicidal compound.

The global market for herbal drugs has registered a steady increase over the last two decades (Dhar et al. 2000, Martinez 1995, 1997, Olsen 1998), and annually exceeds over U.S.\$20,000 million (Dhar et al., 2000, Valiathan 1998). The world trade records suggest that India ranks next to China in annual exports (32,600 tonnes: US\$46 million) of medicinal raw materials (Dhar et al. 2000, Lange 1997). All of these records indicate that medicinal plants offer a great motivation for conservation (Dhar et al. 2000, Marshall 1997) for all those concerned about human health care and the economy.

In India, traditional systems of medicine together with folklore systems continue to serve a large portion of the population, particularly in rural areas, in spite of the advent of the modern medicines. In forthcoming sections, we will review the ethnomedicinal plants from different sections of India, followed by ethnomedicinal plants of Mizoram, as an outcome of our research during the last ten years. 


\section{Ethnomedicinal plants of Western Ghats and Southern India}

The Western Ghats is a global biodiversity hotspot extending to Sri Lanka (Conservation International 2005, Mittermeier et al. 2004). It harbors over 8000 medicinal plants of which 2242 have been recorded for the state of Maharashtra, India (Kareem Abdul 1997). The documented ethnomedicinal plants in Maharashtra were mostly used to treat skin disorders, diarrhea, jaundice, tuberculosis, stroke, migraine, menstrual problems, fertility problems, urinary problems, piles, wounds and poisonous bites (Jagtap et al. 2006). Seventy-six ethnomedicinal plants are being used traditionally in Mysore and Coorg district of Karnataka, India (Kshirsagar \& Singh 2001).

An ethnobotanical survey was carried out among the ethnic groups (Kani/Kanikaran) in Southern Western Ghats (Ayyanar \& Ignacimuthu 2005, Hebbar et al. 2004, Mahishi et al. 2005). Traditional uses of 54 plant species belonging to 26 families are described under this study (Ayyanar \& Ignacimuthu 2005). The survey by Mahishi et al. (2005) revealed the utilization of 47 species of plants belonging to 46 genera in 28 families used to treat nine infectious and 16 non-infectious diseases in Shimoga district of Karnataka. In the Dharwad district of Karnataka in Southern India 35 plants belonging to 26 families are being used to treat different types of oral ailments (Hebbar et al. 2004). A total of 101 species of plants are used by Paliyar tribals in Theni district of Tamil Nadu, India, belonging to 90 genera and 48 families. These were reported with the help of standardized questionnaires among 15 tribal informants (Ignacimuthu et al. 2008). Savithramma et al. (2007) recorded the indigenous knowledge of Natuvaidyulu on plants to treat asthma and provided comparison of some plants with clinical uses of the species of Andhra Pradesh. The Virudunagar Hill region of Tamil Nadu, known for rare herbs, contains several medicinal plants used by traditional Ayurvedic and Siddha practitioners and by tribal practitioners (Rajendran et al. 2004).

\section{Ethnomedicinal plants of Northern India}

The Northern part of India constitutes four main broad regions: the Montane region; the sub-Montane region; the Northern plains; and the arid region. Nomadic tribes and pastoral communities dwelling in the North-West and Trans-Himalaya, e.g., Jammu and Kasmir, India, are reputed to have mastered their traditional practices and knowledge about plants used to combat different diseases (Sharma \& Singh 2006). The herbal folk medicine in North India is commonly made available through the herbalists, elderly persons, sadhus (hermits), ojhas (village traditional healers practising their religion), and the traditional street vendors whether in the alpine region near the snows or in the arid region near the deserts. Some of the herbs used by local medical practitioners in Ladakh, India are popularly known as amchis. The amchi system has a large following in Ladakh or Little Tibet (India) and has been practised for centuries (Ball 1986, Navchoo \& Buth 1989). The system resembles, in some broad aspects, the Ayurvedic system but has its own characteristics. It makes use of minerals, hot water springs, puncturing of veins, branding, and herbs (Navchoo \& Buth 1989). Wiley (2002) illustrated widespread and increasing usage of biomedical services for prenatal care and birth among women in Ladakh. Ballabh \& Chaurasia (2007) assessed and documented the new information on medicinal plants used for the treatment of cold, cough and fever by the traditional Amchis of Ladakh. Further, Ballabh et al. (2008) document new ethno-medico-botanical information and traditional use of medicinal plants against kidney and urinary disorders, and thus aimed to conserve the rapidly disappearing traditional knowledge system of the amchis of Ladakh.

One hundred-twentyfive plants from 57 families were collected in order to explore ethnobotanical information with the help of local informants and other elders of the Gond and Kharwar communities in Singrauli region of Uttar Pradesh, India (Singh et al. 2002) which is undergoing serious environmental degradation (Singh et al. 1991). Similarly, in different remote villages and adjacent forest areas of Moradabad district, 45 plant species of 43 genera belonging to 27 families of angiosperms have been recorded as folk veterinary medicines (Ali 1999). Likewise, a field survey of the Sitamata wildlife sanctuary of Chittorgarh and Udaipur district located in the south-west region of Rajasthan was carried out in order to document the medicinal utility of herbs occurring in this area (Jain et al. 2005). Two hundred fourty-three genera belonging to 76 families have been reported which are used by the tribal peoples of about 50 villages around the sanctuary for primary health care to treat various ailments (Jain et al. 2005). Commercial exploitation of species like Arisaema tortuosum (Wall.) Schott, A. racemosus, Bombax ceiba L., Pueraria tuberosa (Roxb. ex Willd.) DC., Eulophia ochreata Lindl., Chlorophytum borivilianum Santapau \& R.R. Fern., Gloriosa superba L., Piper nigrum L., Costus speciosus (J. König) Sm., Ceropegia bulbosa Roxb., Ceropegia candelabrum L., Dioscorea hispida Dennst., Kydia calycina Roxb., Leea macrophylla Roxb. ex Hornem. and Sterculia urens Roxb. has been reported from Rajasthan (Jain et al. 2005). Twentyfour ethnomedicinal and ten obnoxious grasses of Rajasthan were reported by another group (Katewa \& Sharma 1998, Katewa et al. 2001). A field study of twelve districts of arid zones of Rajasthan was undertaken to evaluate the occurrence of three selected endangered medicinal plant species (Leptadenia reticulata (Retz.) Wight \& Arn., Mitragyna parvifolia (Roxb.) Korth., Withania coagulans (Stocks) Dunal), and arbuscular mycorrhizal fungal (AMF) associations with them (Panwar \& Tarafdar 2006). Panwar \& Tarafdar (2006) revealed that the association with AMF of these plant species native to the harsh environmental conditions of the Indian Thar Desert may play a significant role in 


\section{Rai \& Lalramnghinglova - Ethnomedicinal Plants of India with Special Reference to an Indo-Burma Hotspot Region: An overview}

the reestablishment and conservation of aforesaid multipurpose endangered medicinal plants. Singh \& Lal (2008) highlighted the new or lesser known medicinal uses of plants along with validation of traditional knowledge. Screening for toxin-neutralizing effects in case of snake bites was provided by Samy et al. (2008).

\section{Ethnomedicinal plants of Eastern and North-East (NE) Indian Himalayas}

The Himalayan medicinal plants are the major contributors to traditional systems of medicine in India. These plants have been a source of medicine for millions of people in the country and elsewhere in the world. Plant diversity of the Himalayas includes over 8000 angiosperms, 44 gymnosperms, 600 pteridophytes, 1737 bryophytes, and 1159 lichens etc. (Dhar et al. 2000, Singh \& Hajra 1996). Of these, 1748 are used for various therapeutic purposes (Kala 1998a,b, 2000, 2002a,b, Kala et al. 2004, Paliwal \& Badoni 1990, Samant et al. 1996, 1998, 2001). Uttaranchal, eastern India, has more than 3500 higher plant species. Among the various tribal ethnic groups of Uttaranchal, the Tharu, Buxas, Rajis, and Bhotiyas largely depend on wild resources (Farooquee 1994, Farooquee \& Nautiyal 1999, Farooquee \& Saxena 1996, Gaur 1999, Kala et al. 2004, Maikhuri et al. 1998, 2000, Nautiyal et al. 2000).

A total of 300 plant species used in treating 114 ailments in various cultural communities of Uttaranchal were documented and it was found that herbs contributed the highest number of medicinal plants $(65 \%)$, followed by shrubs (19\%) and trees (16\%) (Kala et al. 2004). In Eastern Himalaya, Vitex negundo L. was the most important species, used for the treatment of more than 48 ailments while A. indica, Woodfordia fruticosa (L.) Kurz, Centella asiatica (L.) Urb., Aegle marmelos (L.) Corrêa, Cuscuta reflexa Roxb., Butea monosperma (Lam.) Taub., Phyllanthus emblica L., and Euphorbia hirta L. were among other important medicinal plants based on their high use values (Kala et al. 2004).

The Northeastern (NE) States of India comprising eight states that harbor more than 180 major tribal communities of the total 427 tribal communities found in India (Sajem et al. 2008). A large part of the NE India is botanically under-explored or even unexplored (Jain \& Dam 1979). Jain \& Dam (1979) conducted an ethnobotanical study of 48 plants from NE India. The tribes of the Himalayan region also have ethnomedicinal traditions for which little literature is available (Bennet 1983, Biswas 1956, Das \& Lalramnghinghlova 1999d, 2000, 2001, Lalramnghinghlova \& Jha 1997, Lalramnghinghlova et al. 1997, Mandal 2003, Pandey 1991, Rai 2009, 2010b,c, 2011a,b, Rai \& Bhujel 1999, 2002, Rai \& Sharma 1994, Rai et al. 1998, Singh et al. 2002, Srivastava et al. 1987, Venu et al. 1990, Yonzone et al. 1984). Chhetri et al. (2005) found that 37 species of plants belonging to 28 families are used as an- tidiabetic agents in the folk medicinal practices in the region and $81 \%$ of these plants are unreported as hypoglycemic agents. In Sikkim, a NE state, six important species of medicinal plants (Aconitum heterophyllum Wall. ex Royle, Nardostachys jatamansi (D. Don) DC., Podophyllum hexandrum Royle, Picrorhiza kurrooa Royle ex Benth., Swertia chirayita (Roxb.) H. Karst. and Bergenia ciliata Sternb.) were determined to be threatened. Shankar (2003) studied the distribution pattern and conservation status of Aconitum fletcheranum G. Taylor in NE Himalaya.

Further, an ethnobotanical survey carried out in the district of North Cachar hills, Assam, NE India which revealed 34 species of plants to be threatened in several parts of the country, and in the district itself (Sajem et al. 2008). Out of this, six species of plants are included in the Red Data Book of Indian Plants and five species have already been included in the Red Data List of the IUCN (Sajem et al. 2008). An ethnobotanical survey of medicinal plants used in the treatment of gynecological disorders was carried out among the rural people in Tinsukia district, Assam, India. Aerva sanguinolenta (L.) Blume, Amaranthus spinosus L., Ananas comosus (L.) Merr., Baccaurea ramiflora Lour., Carica papaya L., Caryota urens L., Cicer arietinum L., Croton joufra Roxb., Curcuma longa L., Cynodon dactylon (L.) Pers., Eleusine indica (L.) Gaertn., E. hirta, Ipomoea aquatica Forssk., Justicia adhatoda L., Lasia spinosa (L.) Thwaites, Mollugo pentaphylla L., Meyna spinosa Roxb. ex Link, P. nigrum, Vandellia scabra Benth. among others were found to be extremely useful for the aforesaid purpose (Buragohain 2008). Laboratory and clinical support for these folk herbal medicines might lead to potential drugs.

Ethnobotanical studies in Orrisa were conducted by Sankar (2003). In Mayurbhanj district of Orrisa, 58 plant species belonging to 34 families used in folk medicine have been documented (Rout et al. 2009). Due to poverty and the poor conditions of modern healthcare facilities, indigenous people of Orrisa fully or partially depend on local medicinal plants. An ethnomedicinal survey among the local communities in the Kuldiha wildlife sanctuary of the Balasore district, Orissa, India indicated traditional uses of 49 plant species belonging to 32 plant families (Pattanaik \& Reddy 2008).

Sacred groves of NE India are a reservoir of medicinal plants (Laloo et al. 2006, Mishra et al. 2004). The indigenous tribes have protected the groves since time immemorial due to their various religious beliefs attached to them. Besides acting as a gene pool and providing refuge to a large number of endemic, endangered and threatened species (Jamir \& Pandey 2002, 2003), they render ecological services such as being sources of perennial water, maintaining local micro-environmental conditions and helping in biogeochemical cycles (Upadhaya et al. 2003). In Nagaland, the native population is comprised 
of some fifteen tribes (e.g., Angami, Ao and Lotha) each with their own traditional medicines (Jamir et al. 1999). Jamir et al. (1999) reported 36 plant species used to address ailments of gastro-intestinal, dermal, respiratory, cardiac, dental systems. Plants and plant parts are used in different dosage forms, the most common being fresh juice, decoction, infusion and dry powders. External applications of drugs are indicated for ailments like cuts and wounds, dermatitis, sprains and swelling. Sometimes, the drug is taken by chewing a particular plant part (Jamir et al. 1999). There are records of about 400 plants of therapeutic value in the Sikkim Himalaya (Chhetri et al.2008, Rai et al. 2000).

Kayang (2007) enumerated various aspects of the wild plants used by Khasi, Jaintia and Garo tribes of Meghalaya, NE India. These plants not only provide inexpensive food but several other useful products like medicine fiber, fodder, dyes, etc. In his specific study, Sharma et al. (2001) reported 135 plant species from 122 genera in 65 families utilized in certain spots of Mizoram.

\section{Anthropocentric Approach: Threat to Ethnomedicinal Plants}

Our planet is witnessing rapid changes in the composition of plant and animal species through over-exploitation of natural resources. Farming, lumbering and mining activities have particularly contributed to habitat loss. Deforestation, in particular, has had tremendous ramifications for the practice of ethnomedicine in many areas (Anyinam 1995). Existing estimates of species range from 1 to 50 per day, or a total of 365 to 18,250 each year. Of the estimated 250,000 known plant species, about $25 \%$ are expected to be extinct by the year 2050 (Anyinam 1995, Kaufman 1993).

At the broader level, some species are endemic to particular countries. For example, of approximately 10,000 plant species that grow on the island of Madagascar, half are endemic, i.e., they are not naturally found growing in other global ecosystems (Anyinam 1995). Reports indicate that many species are almost extinct in Madagascar due to extensive deforestation and marked soil erosion facing the island (Anyinam 1995, Jolly \& Landting 1987). Elsewhere, such as in North America, some endangered species (e.g., bears) have fallen victim to illegal trade. South Korea appears to be the largest consumer of these North American bear parts (Anyinam 1995).

The practice of ethnomedine has been also indirectly affected by loss of indigenous cultural communities and their traditional knowledge. The destruction of tropical forests has meant, in many parts of the tropical region, increasing disappearance of native people who have been living in these areas and who have accumulated a compendium of folk knowledge about the usefulness of plants for treating various diseases (Anyinam 1995, Daniels et al. 1995). The declining number of indigenous people in many parts of Latin America illustrates the problems of disappearing societies (Anyinam 1995). When discovered by Europeans in the fifteenth century, the Amazon had an indigenous population estimated at six million or more (Anyinam 1995, Bunker 1985, Carneiro 1988, Denevan 1976). Approximately 250,000 remain today, distributed among more than 200 ethnic groups (Anyinam 1995, Schreider \& Schreider 1970). One-third of the Amazonian tribes known to exist in 1900 are now said to be extinct (Anyinam 1995, Hecht \& Cockburn 1989, Lewis et al. 1991). For example, Amazonian Ecuador supported 17 distinct ethnic groups before European contact but today, only seven remain. As part of their objective to Christianize the indigenous populations, the rich ethnobotanical knowledge of the Aztecs and other precolonial Meso American cultures was deliberately and systematically destroyed by the Spanish invaders (Anyinam 1995, Diaz 1977). However, the existence of these groups of people actually has contributed immensely to saving tropical forests from capitalist exploitation.

Likewise, in India, indiscriminate and non-systematic collection of medicinal plants has led to severe pressure on the availability of these plants, many of which are now rare, threatened or endangered. In the current scenario, medicinal plants are under extreme pressure due to their excessive collection or exploitation (Laloo et al. 2006, Mulliken \& Schippmann 2007, Sajem et al. 2008). Rapid and continuous exploitation of several medicinal plant species and substantial loss of their habitats have resulted in the population decline of these species over the years (Kala \& Sajwan 2007, Mulliken \& Schippmann 2007, Planning commission 2000, Sajem et al. 2008). Further, the degree of threat to natural populations of medicinal plants has increased because more than $90 \%$ of medicinal plant raw material for herbal industries in India and also for export is drawn from natural habitats (Dhar et al. 2002, Sajem et al. 2008). There are many other potential causes of rarity in medicinal plant species, such as habitat specificity, narrow range of distribution, land use disturbance, introduction of non-natives, habitat alteration, climatic changes, heavy livestock grazing, explosion of human population, fragmentation and degradation of population, plant population bottlenecks and genetic drift (Kala 2000, 2005, Oostermeijer et al. 2003, Rao et al. 2004, Sajem et al. 2008, Weekley \& Race 2000). Over-exploitation of these species, as well as trampling during collection has changed their habitat conditions causing a gradual loss of other associated species (Rai et al. 2000). Degradation and destruction of natural systems also poses a threat to sacred sites and spaces designated by local healers and people (Anyinam 1995). Lately much concern with commercially collected medicinal plants has been voiced, and the general perception is that the resource is being overexploited (Larsen et al. 2000, Sharma 1995, Shrestha \& Joshi 1996). 


\section{Rai \& Lalramnghinglova - Ethnomedicinal Plants of India with Special Reference to an Indo-Burma Hotspot Region: An overview}

Indigenous healers traditionally have been collecting medicines from local plants and animals probably without threatening the population dynamics of the species because of the low level of harvesting. In the last few decades, however, there has been a marked increase in the sale of herbal remedies. This has precipitating large-scale harvesting of medicinal plants and factory-like production of herbal drugs in many parts of developing countries (Anyinam 1995). In India, the collection of medicinal plants for sale in the markets forms an important part of the livelihood of the local inhabitants in forested areas. Traders also send their own workers into the forests to collect medicinal plants (Alok 1991, Anyinam 1995). The exploitation of wild-growing Rauvolfia serpentina (L.) Benth. ex Kurz in India for export exhausted the supply to a point where the Indian government several years ago placed an embargo on the export of this plant (Akerele et al. 1991, Anyinam 1995). Another example of a plant that has been over-exploited in India for export to other Asian countries is Coptis teeta Wall., which is considered an endangered species in India (Alok 1991, Anyinam 1995).

In 2002, the World Summit on Sustainable Development re-affirmed the commitment of parties to the Convention on Biological Diversity to reduce the rate of biodiversity loss by 2010 . Achieving this goal (itself only the first step towards halting, and eventually reversing, biodiversity loss) will require concerted and well focused action, not just by governments but also by a very wide range of organizations and individuals. TEK and its relation to biodiversity conservation particularly in the context of ethnomedicinal plants should be given due importance in millennium development goals.

The International Union for Conservation for Conservation of Nature (IUCN) Red List of Threatened Species (IUCN 2009) provides a key tool in helping to achieve this goal. The 2004 IUCN Red List (IUCN 2004) provides objective information on the threat status of an unprecedented number of species. This assessment presents analyses at a range of geographical scales and from ecological and geopolitical perspectives. It examines the nature and impact of threats, and outlines current and potential conservation measures. The IUCN Red List of Threatened Species (also known as the "IUCN Red List" and "Red Data List"), created in 1963, is the world's most comprehensive inventory of the global conservation status of plant and animal species. The different categories frequently used in classification are: Extinct; Extinct in the Wild; Critically Endangered; Endangered; Vulnerable; Near Threatened; Least Concern; Data Deficient; and Not Evaluated. The 1994 version included an additional category that is used for some species, but once they are all reassessed it will no longer be used (IUCN 1994).

Since the amalgamation of the plant and animal Red Lists in the 2000 IUCN Red List of Threatened Species the number of plant assessments has steadily increased (Baillie et al. 2004, IUCN 2009). Of the 11,824 plants evaluated, $70 \%(8,321$ species $)$ are listed as threatened. Although 8,321 threatened species of plants appeared on the 2004 IUCN Red List, the number evaluated against the Red List Criteria represents only about $4 \%$ of the total number of species and almost $3 \%$ of these are threatened (Baillie et al. 2004). Moreover, the IUCN Red List shows that 110 species out of all plants are either extinct (86) or extinct in the wild (24) (Baillie et al. 2004, IUCN 2009). It is a matter of serious concern that 1,490 plants are critically endangered (Baillie et al. 2004, IUCN 2009).

The uneven distribution of threatened species means that a number of countries have a disproportionate number of species at risk of extinction (Baillie et al. 2004). The most threatened species occur in the tropics, especially on mountains and on islands (Baillie et al. 2004, IUCN 2009).

Table 1 presents the threatened taxa recorded from four states of NE India. Seven species in the Himalayan region are categorized as Critically Endangered (Betula utilis D. Don), Endangered ( $P$. hexandrum, Ephedra gerardi-

Table 1. State wise number of threatened and total taxa evaluated from four states of NE India (Source: Ved et al. 2005).

\begin{tabular}{|c|c|c|c|c|c|}
\hline $\begin{array}{l}\text { Assigned Red } \\
\text { List Category }\end{array}$ & $\begin{array}{c}\text { Arunachal } \\
\text { Pradesh }\end{array}$ & Assam & Meghalaya & Sikkim & Total taxa \\
\hline $\begin{array}{l}\text { Critically } \\
\text { Endangered }\end{array}$ & 6 & 1 & 4 & 1 & 9 \\
\hline Endangered & 12 & 8 & 7 & 8 & 22 \\
\hline Vulnerable & 17 & 7 & 13 & 12 & 26 \\
\hline Threatened taxa & 35 & 16 & 24 & 21 & 46 \\
\hline Near Threatened & 8 & 1 & 2 & 2 & 10 \\
\hline Least Concern & 3 & 2 & 1 & 2 & 6 \\
\hline Data Deficient & 1 & 3 & 5 & 9 & 11 \\
\hline $\begin{array}{l}\text { Total taxa } \\
\text { assessed }\end{array}$ & 47 & 22 & 32 & 34 & 50 \\
\hline
\end{tabular}


ana Wall. ex C.A. Mey., and N. jatamansi) and Vulnerable (Bergenia ligulata Engl., B. stracheyi, and Hedychium spicatum Buch.-Ham. ex Sm.) using new IUCN criteria (Samant \& Pant 2006). Nardostachys, in India is reported from the Western Himalayas to the Kumaon Himalayas in the districts Uttarkashi, Tehri, Rudraprayag, Chamoli (in Garhwal), Kumaon; and from the Eastern Himalayas in the districts of Sikkim and Arunachal Pradesh (Shah 2007). Earlier, N. jatamansi was reported to be very common in the Kumaon and Nepal Himalayan region, but now it has become rare due to exploitation by local herb collectors and traders (Shah 2007). No clear cut information about the locations of $N$. jatamansi is available from NE India. Effective strategies should be implemented in order to avoid its extinction.

Medicinal plants may become critically endangered because of their small population size, narrow range of distribution, and/or habitat specificity. Humans may cause them to become critically endangered through destructive modes of harvesting, high use values, over-collection for commercial purposes, habitat alteration, and developmental activities (Dhar et al. 2000, Kala 2000, Samant et al. 1998). Within India rarity status of species has been demonstrated according to the Red Data Book of Indian Plants (Nayar \& Sastry 1987) and the Conservation Assessment and Management Plan (CAMP) workshop (Kala et al. 2004, Ved et al. 1998, Ved \& Tandon 1998). Dactylorhiza hatagirea (D. Don) Soó, Picrorhiza kurrooa Royle ex Benth., A. heterophyllum, Rheum australe D. Don, $P$. hexandrum, and Taxus baccata $\mathrm{L}$. are among 35 rare and endangered medicinal plant species found in Uttaranchal and have become rare and endangered due to over-collection for therapeutic purposes (Kala et al. 2004). In 2004, Taxus chinensis (Pilg.) Rehder, Taxus cuspidata Siebold \& Zucc., Taxus fuana Nan Li \& R.R. Mill, and Taxus sumatrana (Miq.) de Laub. were included in Appendix II of the Convention on International Trade in Endangered Species of Wild Fauna and Flora (CITES). This decision was based on evidence that the species were at risk of being over-harvested in the wild for the purpose of extraction of chemical derivatives used in the production of anti-cancer drugs (i.e., paclitaxel) (IUCN 2007a, Mulliken \& Schippmann 2007). CITES recommended that seven Asian medicinal plants, i.e., Cistanche deserticola Ma, Dioscorea deltoidea Wall. ex Griseb., N. grandiflora, P. kurrooa, Pterocarpus santalinus L.f., R. serpentina, and Taxus wallichiana Zucc. are the responsibility of the range states to ensure the implementation of regionally coordinated actions to improve the management and prevent illegal trade, including among other things, measures to combat illegal trade, regional capacity building workshops, and the harmonization of regulations and legislation (IUCN 2007a, Mulliken \& Schippmann 2007). Celastrus paniculatus Willd., C. orchoides, Gymnema sylvestre (Retz.) R. Br. ex Schult., Hemidesmus indicus (L.) R. Br. ex Schult., Mucuna monosperma (Roxb.) DC., R. serpentina, Saraca asoca (Roxb.) De Wilde, Tylophora indica (Burm.f.) Merr., and Artocarpus hirsutus Lam. are plants that were common in Western Ghats of India but have been added over the years to the IUCN Red List (IUCN 2009)

Bisht et al. (2006) attempted to integrate the analysis of several aspects of Himalayan trade in medicinal plants to reveal the threat to the plants. They suggested ways to overcome problems using Angelica glauca Edgew. as an example. An important example of a plant that has been threatened and is in need of solutions is Taxus baccata, known for the treatment of ovarian and breast cancer, that has been overexploited and smuggled heavily from Western Arunachal Pradesh (Chatterjee \& Dey 1997).

In NE India, trade is a potential cause of threat for 43 taxa. Habitat loss is a common threat to all the taxa, while a few are reportedly also threatened by other causes such as fire. Nepenthes khasiana Hook.f. (listed under CITES Appendix I and Schedule VI of the Wildlife (Protection) Act, 1972) is threatened due to over collection as a botanical curiosity. Dendrobium nobile Lindl. is reportedly threatened on account of over collection for hybridization with domesticated populations (Chaudhari 2007).

Bio-resources of Mizoram comprise a great share of natural resources. The agroecosystems as well as natural ecosystems harbor genetic potential (Lalramnghinghlova 1999b, c, 2002a, b). Lalramnghinghlova \& Jha (1998) described more than 200 medicinal plants used to treat diseases like: bleeding from nose, fever, malarial fever, asthma, tuberculosis, calculi, stones in kidney, gall-bladder, urinary troubles, hypertension, diabetes, stomachache, stomach ulcer, dysentery, diarrhoea, jaundice, hepatomegaly, fracture of bone, and snake bite. They added that over $60 \%$ of people living in the interior parts of the state depend upon herbal medicine. Further, Lalramnghinghlova \& Jha (1997) identified and characterized the ethnomedicinal plants based on IUCN threat categories. Also, Lalramnghinghlova \& Jha (1999) during their survey of ethnomedicinal plants identified new plant uses in forests of Mizoram. Lalramnghinghlova (1999d) marked that although more work has been undertaken on ethnobotany, less focus has been given to ethnozoology which is very necessary in order to address ethnobiology in its totality.

\section{Excessive exploitation by Pharmaceutical Industries}

Ethnopharmacology continues to identify possible new drugs and lead molecules for the pharmaceutical industry (Houghton 2007, Wiart 2006). The recent introduction of artemisinin from Artemisia annua L. as an effective antimalarial is a good example. This is based on its use to treat fevers and malaria-like symptoms in traditional Chinese medicine (Houghton 2007, Wiart 2006). A large amount of information still awaits disclosure to the scientific community particularly plants of Asia and the Pacific (Mulliken \& Schippmann 2007, Wiart 2006). 


\section{Rai \& Lalramnghinglova - Ethnomedicinal Plants of India with Special Reference to an Indo-Burma Hotspot Region: An overview}

Some pharmaceutical companies depend largely upon materials procured from naturally occurring sources that are being rapidly depleted. Although there are many mutual benefits of joint effort between ethnobotanists and pharmacologists, there are also challenges to overcome in order to foster successful partnerships (Kumar 1997). The difference in worldview underlying research objectives of both fields is complex. While bioprospecting (exploring biodiversity for new sources of natural products) is still the objective of some pharmacologists, the field of ethnobotany is generally more concerned about the cultural meaning of the relationship between humans and plants than in mining for plant pharmaceuticals and information about plants (McClatchey et al. 2009).

Most often excessive use of medicinal plants is motivated by immediate and short-term economic gains (Mulliken \& Schippmann 2007, Ved et al. 1998). However, biologists (including conservation biologists, planners, etc.), whose concern is to set conservation priorities have their focused on rarity (Dhar et al. 2000, Rabinowitz et al. 1986), sensitivity, i.e., nativity (proportional representation of native taxa), endemism (Dhar et al. 2000, Rawal \& Dhar 1997) and attempts to measure extent of decline or threat of extinction (Allendorf et al. 1997, IUCN 1994, Mace \& Lande 1991).

\section{Biotechnological Tools in Conservation}

Conservation of valuable plant species in the Himalayan region has become imperative (Dhar 2002, Dhar et al. 2000) due to increasing interest in herbal medicines for health care across the globe (Franz 1993, Kala et al. 2004). The Himalayan region contributes 350 species (Purohit 1997) out of 700 plant species used in industries for making drugs.

Plant tissue culture is an alternative method of commercial propagation (George \& Sherrington 1984) and is being used widely for the commercial propagation of a large number of plant species, including many medicinal plants (Rout et al. 2000). The factors that influence micropropagation of medicinal and aromatic plants have been reviewed by Bhagyalakshmi and Singh (1988), $\mathrm{Hu}$ and Wang (1983), Hussey (1980, 1983), Murashige (1977a), Rout et al. (2000), Short \& Roberts (1991).

The concept of synthetic seed was given by Murashige (1977b) followed by first report on the development of synthetic seeds (Kitto \& Janick 1982). Later, Redenbaugh et al. (1984) were successful in producing synthetic seeds for alfalfa by encapsulating somatic embryos with alginate hydrogel. Since then several scientists have been working on synthetic seeds incorporating encapsulation technology with different plant species of medicinal plants (Faisal \& Anis 2007, Rai et al. 2009, Sharma et al. 1994, Singh et al. 2006a, b, 2009).
Naina et al. (1989) reported the successful regeneration of transgenic neem plants ( $A$. indica) using Agrobacterium tumefaciens Smith \& Townsend, 1907 containing a recombinant derivative of the plasmid pTi A6. Giri et al. (1997) induced the development of hairy roots in $A$. heterophyllum using Agrobacterium rhizogenes (Riker et al. 1930) Conn 1942. Pradel et al. (1997) developed a system for producing transformed plants from root explants of Digitalis lanata Ehrh. They evaluated different wild strains of $A$. rhizogenes for production of secondary products (cardenolides, anthraquinones, and flavonoids) obtained from hairy roots and transgenic plants. They reported higher amounts of anthraquinones and flavonoids in the transformed hairy roots than in untransformed roots.

Guha and Maheshwari (1964) first reported the development of embryos from microspores of Datura inoxia Mill. Corduan and Spix (1975) reported the induction of haploid callus and subsequently plant regeneration from anthers of Digitalis purpurea L. Subsequently, Perez-Bermudez et al. (1985) reported the induction of somatic embryogenesis and plant regeneration from cultured anthers of Digitalis obscura L.

Upadhyay et al. (1989) reported a propagation profile for $P$. kurroa and observed that the shoot multiplication rate gradually improved as the number of subcultures increased. Arora \& Bhojwani (1989) compared the rate of shoot multiplication of Saussurea lappa (Decne.) Sch. Bip. using shoot tip explants. Koblitz et al. (1983) subcultured micropropagated shoots of Cinchona ledgeriana (Howard) Bern. Moens ex Trimen and Cinchona succirubra Pav. ex Klotzsch at weekly intervals and obtained 20,000 shoots from a single apical meristem within one year. Bajaj et al. (1988) observed 2200 plantlets of Thymus vulgaris L. from a single shoot grown in-vitro for 5 months. Rout et al. (1999) demonstrated a significant improvement in shoot multiplication rate by subculturing Plumbago zeylanica L. at 4-week intervals. Ghosh \& Sen (1989) established plant regeneration via callus cultures from different explants of Asparagus cooperi Baker by modifying the composition of the growth medium and physical environment. The relative importance of genotype, explant and their interactions for in-vitro plant regeneration via organogenesis in Solanum melongena L. was studied (Sharma \& Rajam, 1995). Rout \& Das (1997) described in-vitro organogenesis of Zingiber officinale Roscoe via callus culture. In-vitro somatic embryogenesis of medicinal plants, e.g., Acacia catechu (L.f.) Willd., Asparagus officinalis L., A. indica, Bunium persicum B. Fedtsch., Cayratia japonica (Thunb.) Gagnep., Chlorophytum borivilianum Santapau \& R.R. Fern., Dioscorea floribunda M. Martens \& Galeotti, D. obscura, Hyoscyamus niger L., Medicago sativa L., P. hexandrum, Piper betle L., Thevetia peruviana (Pers.) K. Schum., Typhonium trilobatum (L.) Schott, and Z. officinale (Rout et al. 2000). A method has been developed for rapid multiplication of $C$. orchioides through 
direct organogenesis and bulbil formation in-vitro (Suri et al. 1999).

Shoot tips of $D$. deltoidea, a medicinal yam, were cryopreserved using the vitrification and encapsulation-dehydration technique resulting in high-frequency direct plant regeneration (Dixit-Sharma et al. 2005). Dioscorea deltoidea is an important endangered medicinal plant, commercially exploited for the extraction of diosgenin, a precursor of steroidal drugs. Due to indiscriminate harvesting and shrinking of natural habitat, this native Indian species faces a serious threat of extinction. However, the species continues to remain an important natural source of diosgenin. It is still sold at U.S.\$1000 per kg (Das et al. 1999, Dixit-Sharma et al. 2005).

Plant part substitution, a strategy which would satisfy the requirements of sustainable harvesting, yet simultaneously provide for primary health care needs, would be the substitution of bark or underground parts with leaves of the same plant (Zschocke et al. 2000). Zschocke et al. (2000) suggested that every investigation into a medicinal plant must always include an investigation of leaves and other aerial plant parts, even though those might not be the parts traditionally used. Investigations like this, as well as a close interaction with traditional healers and the cultivation of medicinal plants, may protect more species from extinction, and allow the recovery of threatened medicinal plants (Zschocke et al. 2000).

\section{Ethnoveterinary Plants}

Ethnoveterinary research may also lead to important results (Diehl et al. 2004, Lans et al. 2007). For example, Lans et al. (2007) identified twelve plants used for backyard pigs and birds. Crushed leaves of Erythrina pallida Britton and Erythrina micropteryx Poepp. ex Urb. are used to remove dead piglets from the uterus. A leaf decoction of Cecropia peltata L. and Bambusa vulgaris Schrad. ex J.C. Wendl. is used for labor pains or leaves are fed as a postpartum cleanser. Boiled green $C$. papaya fruit is fed to pigs to induce milk let-down and the leaves and flowers of C. papaya plants are fed to deworm pigs. Citrus aurantium $\mathrm{L}$. juice is given to pigs to produce lean meat. Coffee grounds (Coffea sp.) are used for scours. Chenopodium ambrosioides L. and Gossypium species are used as anthelmintics. Aloe vera gel is used for internal injuries and the yellow sap from cut $A$. vera leaf or the juice of Citrus $\times$ limonia (L.) Osbeck is used to purge the birds. Euphrasia sp. and Plantago major L. leaves are used for eye injuries of backyard chickens (Lans et al. 2007).

After finishing the review of ethnomedicinal plants of India, we confine ourselves towards the findings of our own study. The aims of the present study were to: 1) provide an updated account of medicinal plants utilized by the Mizos of Mizoram, India; 2) encourage preservation of Mizos culture and traditional knowledge; and 3) develop recommendations for conservation and sustainable utilization of the plant wealth occurring in the study area.

\section{Study area}

North-East India forms a large portion of both the Himalaya and Indo-Burma biodiversity hotspots. The region, covering approximately $262,379 \mathrm{~km}^{2}$, has been divided into two biogeographic zones - Eastern Himalaya and NE India, based on floristic composition, the naturalness of the flora and the local climate (Rodgers \& Panwar 1988). The North-East region of India contains more than one-third of the country's total biodiversity.

Takhtajan (1980) treats this region as the 'Cradle of flowering plants'. Among insectivorous plants $N$. khasiana, endemic to Meghalaya and Drosera peltata Thunb. and Drosera burmanii Vahl. are important. Many families, represented in India by solitary genera with one or two species are in this region, e.g., Coriariaceae, Nepenthaceae, Illiciaceae, Ruppiaceae. The genus Rhododendron (Ericaceae) is a remarkable group of showy plants with nearly $98 \%$ of the total Rhododendrons reported from India confined to Himalayan region. According to Vavilov (1992, 1997), the NE region of India forming the 'Hindustan Center of Origin of Cultivated Plants' is very important for tropical and sub-tropical fruits, cereals, etc.

Study area, Mizoram state, covers an area of 21,087 km² and is sandwiched between Myanmar (Burma) and Bangladesh (Figure 1). Mizoram extends between $21^{\circ} 58^{\prime}$ to $24^{\circ} 45^{\prime} \mathrm{N}$ latitute and $92^{\circ} 15^{\prime}$ to $93^{\circ} 29^{\prime} \mathrm{E}$ longitude. Temperature varies from 18 to $29^{\circ} \mathrm{C}$ in summer and from 11 to $24{ }^{\circ} \mathrm{C}$ in winter. There is no snowfall anywhere in Mizoram, though frost is experienced in the eastern region. Mizoram is under direct influence of monsoons, with heavy rains from May to September and an average rainfall of $245 \mathrm{~cm}$ per year (Sharma et al. 2001). Table 2 represents the population status of Mizoram and Aizawl according to a 1991 census which clearly indicates that most of the population of Mizoram is concentrated in Aizawl and there is an almost equal distribution of men and women.

The vegetation of Mizoram, according to the proposed classification, is tropical evergreen and semi-evergreen forest in the lower altitude hills; sub-tropical to montane sub-tropical in the high hills (Rai 2009). The total forest area is $15,825 \mathrm{~km}^{2}$. Forests are growing from 500 to 2,157 $\mathrm{m}$ in altitute. However, these forests are exposed to various anthropogenic disturbances, e.g., shifting cultivation, timber logging, extraction of fuel wood by poor/rural tribals, industrialization and in fact urbanization in some parts of Mizoram like Aizawl. The relationship between the indigenous people of the region and the vegetation is considered to be both advantageous as well as detrimental to the plant wealth of Mizoram. 


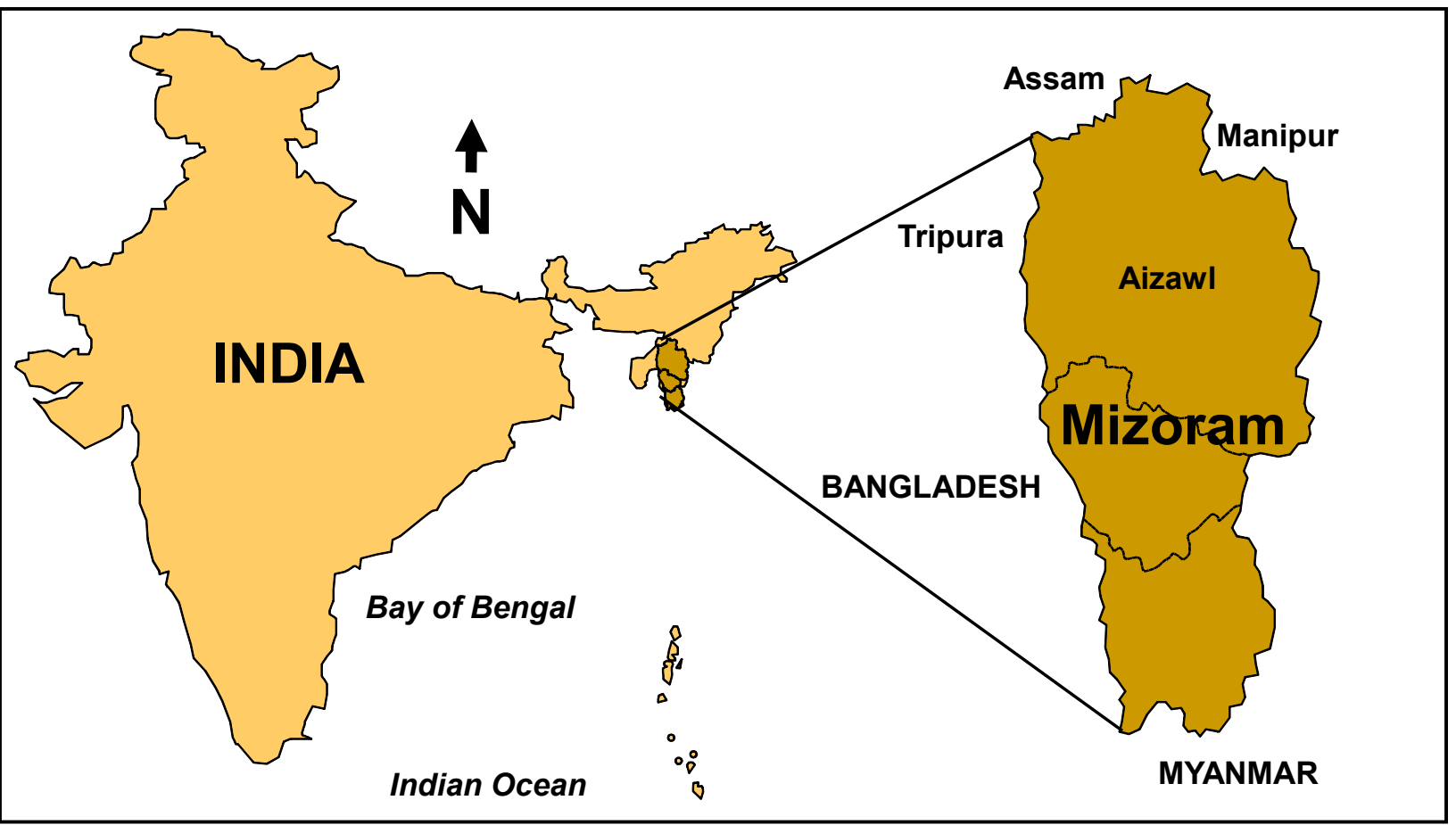

Figure 1. Location of study area in NE India (an Indo-Burma hotspot) in the state of Mizoram.

Mizo tribes of Mizoram are Sino-Tibetan in origin (Lewis 2009). Generally they are people with yellow complexion, oblique eyes, high cheekbones, sparse hair and medium height. Different tribes in Mizoram are Lushai, Mara, Lai, Chakma, Bru/Riang, Pang, Bawm and Mog/Magh (Lalramnghinghlova 2003).

In Mizoram the number of doctors and other medical staff is very low in comparison to the total population (ratio doctors to total population was 1:3,415) (Rai \& Lalramnghinglova 2010a, Sharma et al. 2001). Moreover, the topography of Mizoram is responsible for an under developed communication system. Thus, the people of the rural areas cannot take advantage of modern treatment methods and they instead rely on remedies from nature (Rai \& Lalramnghinglova 2010a, Sharma et al. 2001).

\section{Methodology}

During the study period (1999-2008), indigenous people belonging to different tribes were interviewed about the mode of use and local names for plants by the second author by Lalramnghinghlova (Lalramnghinghlova \& Jha 1998, Lalramnghinghlova 2003). Plants from different forest types and protected areas of Mizoram, home gardens, herbal gardens were collected in conjunction with the interviews. These were identified with assistance from Vanaspati Van and the Botanical Survey of India, Howrah, West Bengal herbarium (CAL) where the specimens are deposited.

The indigenous people are hesitant to transfer their indigenous knowledge acquired from their ancestors. However, traditional medical practitioners were cooperative helping on two field trips per year. Ethnobotanical data were collected according to the methodology suggested by Jain (1964). Plant parts used were also characterized. Only corroborating information obtained from at least three traditional practioners has been reported here. Field data assessment and comparison was conducted according to Heinrich et al. (2009). A guideline for Application of IUCN Criteria at Regional Levels was adopted for threat assessment (IUCN 2004). Red Listed Species documented in the study area were morked according to Nayar \& Sastry (1990). SPSS 11.5 version was used for regression analy-

Table 2. Population distribution in Mizoram and Aizawl, N.E. India. Source: Sharma et al. 2001.

\begin{tabular}{|l|l|l|l|l|l|l|}
\hline & \multicolumn{2}{|l|}{ Mizoram } & Aizawl & \multicolumn{2}{l|}{ Total } \\
\cline { 2 - 7 } & Male & Female & Total & Male & Female & 218744 \\
\hline Rural & 194414 & 177396 & 371810 & 114630 & 104114 & 259721 \\
\hline Urban & 164564 & 153382 & 317946 & 133713 & 126008 & 478465 \\
\hline Total & 358978 & 330778 & 689756 & 248343 & 230122 & \\
\hline
\end{tabular}


sis between ethnomedicinal plant species recorded and families. Further, correlation coefficients were assessed between different life forms of dominant families.

\section{Results}

304 plants from 96 families were identified as medicinal (Table 3). Regression analysis revealed a significant and positive regression relationship (0.442) between total ethnomedicinal plant species recorded and plant families. Just a few families dominate and some families are represented by only single species. Ten dominant families shown in Figure 2 have a significant and positive regression with the lesser represented families. Medicinal plants from all families showed significant positive regression (0.95) with the number of ethnomedicinal plants from dominant families.

Fabaceae (25) followed by Asteraceae (16) contributed the highest number of medicinal plants. Distribution of major families into diverse life forms is represented in Figure 2. The total number of life forms within dominant families was positively correlated. Shrubs were uniformly represented throughout. Trees and herbs have shown a significant and negative correlation (-.659) while other life forms were unrelated with respect to each other.

\section{Endangered (EN)}

Mesua ferrea L. is common in Mizoram (having status of state plant), whereas, it is EN in Darjeeling Himalaya. Dalbergia pinnata (Lour.) Prain is EN at a regional scale, while, Dalbergia horrida is DD (data deficient) status. Dendrobium denudans D. Don is EN in NE India and Mizoram while at a global scale Dendrobium ovatum (L.) Kraenzl. is at Lower Risk (LR). Garcinia lanceifolia Roxb. (EN) and Garcinia cowa Roxb. (LR) at regional level, whereas, at a global level Garcinia indica Choisy is VU. Garcinia pedunculata Roxb. ex Buch.-Ham. is Near Threatened (NT). Garcinia coronaria is LR at regional scale as is G. gummifera at a global scale. Hydnocarpus kurzii is EN in NE India but by our observations should be CR. Rauvolfia serpentina is EN.

\section{Vulnerable (VU)}

Saraca asoca is VU/EN in Mizoram. Cyclea fissicalyx is EN while in our regional study Cyclea peltata is VU. Elaeagnus pyriformis at regional scale is VU, while, Elaeagnus conferta corresponds to LR. Aquilaria malaccensis Lam. is currently listed as VU but based on our observations should be moved to $C R$.
Examination of the IUCN Red Listed Species identified through this study is informative about the complexity of issues (IUCN 2009). The following results are sorted primarily by the IUCN category with additional observations from this work.

\section{Extinct (EX)}

No extinct species were found through this project.

\section{Extinct in the Wild (EW)}

Aegle marmelos (L.) Corrêa is EW at the regional scale.

\section{Critically Endangered (CR)}

Ilex khasiana Purkay. is CR in NE India. Syzygium travancoricum Gamble is CR, while in our study, Syzygium cerasoides (Roxb.) Raizada, was identified under a threatened category.

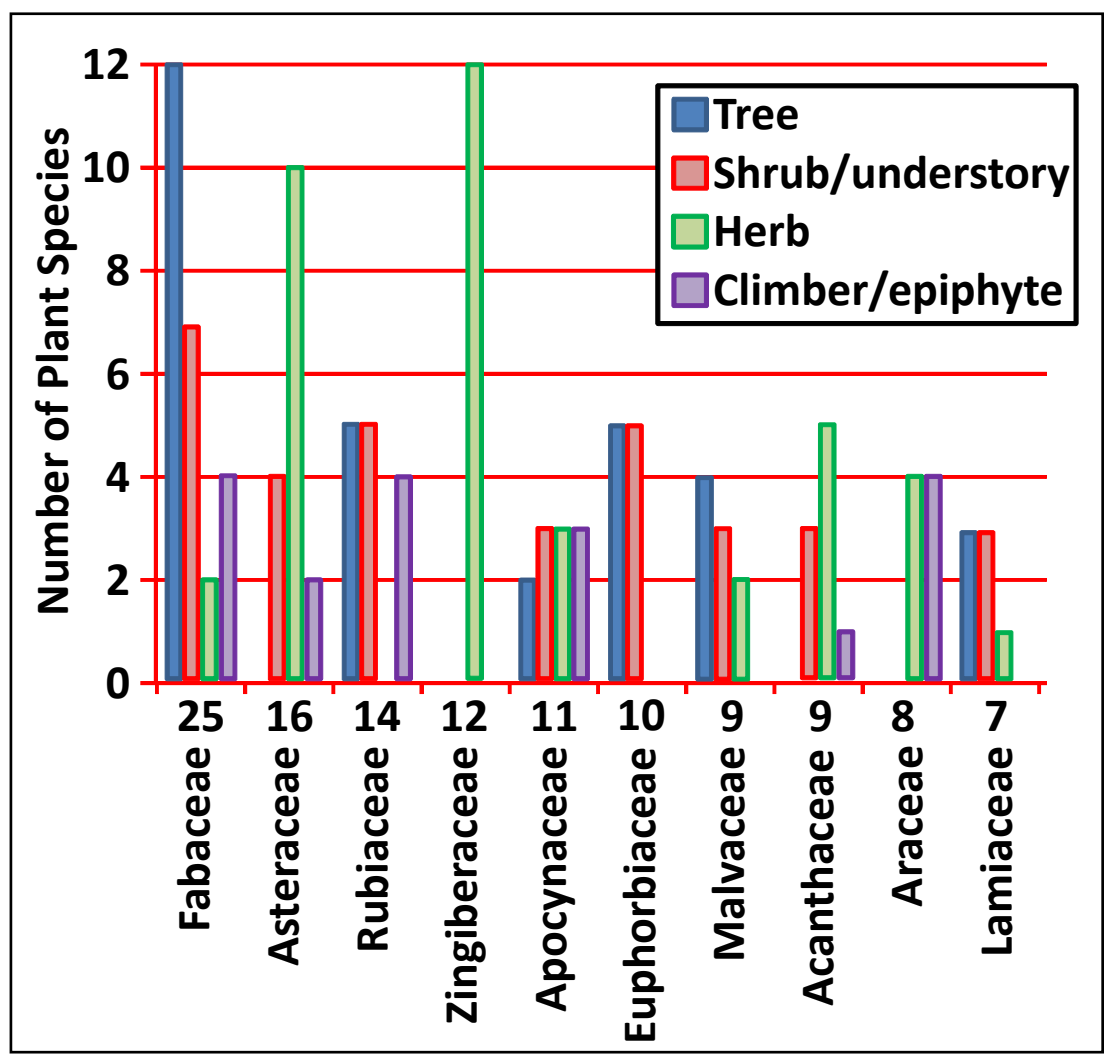

Figure 2. Species growth habits of ethnomedicinal plants in the ten dominant plant families. These were documented in Mizoram, India. 


\section{Rai \& Lalramnghinglova - Ethnomedicinal Plants of India with Special Reference to an Indo-Burma Hotspot Region: An overview}

Table 3. Ethnomedicinal plants recorded from Mizoram, N.E. India: An Indo-Burma hotspot. (Modified or updated from prior work (Lalramnghinghlova 2003, Rai \& Lalramnghinglova 2010a,b. Status: A- C-cultivated, CR-critically endangered, DD-data deficient, E-endemic to NE India, EN-endangered, EW-extinct in wild, I-invasive, IN-introduced \& naturalized, LR-lower risk/conservation dependent, NT-near threatened (includes lower risk/near threatened), VUvulnerable, W-weedy. Parts Used: A-aerial parts, B-bark, Br-branches, Bu-buds, Ch-charcoal, F-flowers, Fr-fruit, G-gum, IS-immature stems, L-leaves, La-latex, P-pulp of fruit, Pe-petioles, Pi-pith, R-roots, Re-resin, Rh-rhizomes, Rs-root stock, S-seeds, Sa-sap, SC-seed coat, Sh-shoots, So-seed oil, Sp-spadix \& fruiting body, St-stem, T-tubers, W-wood, WP-whole plants. Species marked in red have uses from Mizoram that are published here for the first time.

\begin{tabular}{|c|c|c|c|c|c|}
\hline Scientific name & Family & Local name & Habit & Status & $\begin{array}{l}\text { Part } \\
\text { Used }\end{array}$ \\
\hline \multicolumn{6}{|l|}{ Mode of Utilization/Uses } \\
\hline Abelmoschus moschatus Medik. & Malvaceae & Uichhuhlo & Herb & LR & $L, R, S$ \\
\hline \multicolumn{6}{|c|}{$\begin{array}{l}\text { Boiled } R \& L \text { are administered for the remedy of syphilis. Crushed } R \text { are applied externally on wounds/ulcers to suck } \\
\text { the pus out. S are ground to powder \& the powder is taken with water for throat-pain twice daily. }\end{array}$} \\
\hline Acacia pennata (L.) Willd. & Fabaceae & Khangsen & Tree & DD & $B, L$ \\
\hline \multicolumn{6}{|c|}{ B is an antidote for snake poison, \& used in bronchitis $\&$ asthma. $L$ are used for stomach ache $\&$ bleeding gums. } \\
\hline Acer laevigatum Wall. & Sapindaceae & Thingkhim & Tree & LR & B \\
\hline \multicolumn{6}{|c|}{ A decoction of $B$ is applied externally for the remedy of muscle strain. } \\
\hline Achyranthes aspera L. & Amaranthaceae & Buchhawl & Herb & LR & WP \\
\hline \multicolumn{6}{|c|}{ Taken for the remedy of dysentery, colic diseases, in boils \& cirrhosis. } \\
\hline Achyranthes bidentata Blume & Amaranthaceae & Vangvat-tur & Herb & LR & $L$ \\
\hline \multicolumn{6}{|c|}{ The $L$ are crushed \& the juice is applied to treat a poisoned leach bite. } \\
\hline Adhatoda zeylanica Medik. & Acanthaceae & Kawldai & Herb & LR & $\mathrm{L}$ \\
\hline \multicolumn{6}{|c|}{$\begin{array}{l}\mathrm{L} \text { are antispasmodic, used in chronic bronchitis, as antidiarrheal, expectorant, antirheumatism, \& insecticidal. R are } \\
\text { antiseptic, antiperiodic, antithelminthic, \& antigonorrheal. F \& Fr are also antispasmodic. }\end{array}$} \\
\hline Adiantum caudatum $\mathrm{L}$. & Pteridaceae & Chakawkria & Herb & LR & $\mathrm{Fr}$ \\
\hline \multicolumn{6}{|c|}{ The Fr are crushed \& applied externally on skin diseases. } \\
\hline Adiantum philippense L. & Pteridaceae & Chakawkte & Herb & LR & WP \\
\hline \multicolumn{6}{|c|}{ An infusion of the WP is taken for the remedy of fever \& dysentery. } \\
\hline Aeginetia indica $\mathrm{L}$. & Orobanchaceae & Sanghar-vaibel & Epheme- al & CR/VU & $\mathrm{R} / \mathrm{Rh}$ \\
\hline \multicolumn{6}{|c|}{$\begin{array}{l}\text { Juice of the Rh is applied to mumps \& inflammatory glands. R in combination with other plants are prescribed as pills } \\
\text { for fertility. }\end{array}$} \\
\hline Aegle marmelos L. & Rutaceae & Belthei & Tree & EW/VU & $\mathrm{P}$ \\
\hline \multicolumn{6}{|c|}{ A decoction of Fr is applied for the remedy of dysentery, stomach ache \& digestive problems. } \\
\hline $\begin{array}{l}\text { Aeschynanthus sikkimensis } \\
\text { (C.B. Clarke) Stapf }\end{array}$ & Gesneriaceae & Bawltehlantai & $\begin{array}{l}\text { An epiphytic } \\
\text { undershrub }\end{array}$ & LR & L,F,Rs \\
\hline \multicolumn{6}{|c|}{$\begin{array}{l}\text { The } L \& \text { Rs are used for the remedy of fever \& pain. Juice of crushed } L \text { are applied for inflammatory glands. An } \\
\text { infusion of } F \text { is taken for the remedy of tonsillitis. }\end{array}$} \\
\hline Ageratum conyzoides L. & Asteraceae & Vailenhlo & Herb & LR & $\mathrm{R}$ \\
\hline \multicolumn{6}{|c|}{$\begin{array}{l}\text { The } R \text { is crushed with Callicarpa arborea B \& rhizome of Curcuma longa \& the juice is drunk for the remedy of } \\
\text { stomach cancer. St \& L are used as antidiarrheal \& also aid in blood clotting. }\end{array}$} \\
\hline Albizia procera (Roxb.) Benth. & Fabaceae & Kangtekpa & Small tree & LR & $B, L, R$ \\
\hline \multicolumn{6}{|c|}{ A poultice of $L$ are applied to ulcers. The crushed $B$ is used for fish-poisoning. } \\
\hline Albizia odoratissima (L.f.) Benth. & Fabaceae & Kangteknu & Tree & LR & $\mathrm{L}$ \\
\hline \multicolumn{6}{|c|}{ The $L$ are boiled in ghee \& is used in remedy for cough. } \\
\hline Allophylus cobbe (L.) Raeusch. & Sapindaceae & Gendrama & Shrub & LR & $L, R$ \\
\hline
\end{tabular}




\begin{tabular}{|c|c|c|c|c|c|}
\hline Scientific name & Family & Local name & Habit & Status & $\begin{array}{l}\text { Part } \\
\text { Used }\end{array}$ \\
\hline \multicolumn{6}{|l|}{ Mode of Utilization/Uses } \\
\hline Alocasia fornicata (Roxb.) Schott & Araceae & Baibing & Herb & LR & $\mathrm{Sp}$ \\
\hline \multicolumn{6}{|c|}{ The sap or juice of the plant is applied on a snake bite. } \\
\hline Alpinia bracteata Roscoe & Zingiberaceae & Aichal & Herb & LR & $\mathrm{Rh}$ \\
\hline \multicolumn{6}{|c|}{ Powdered Rh with that of Zingiber officinale Roscoe \& a little salt is used for the remedy of stomatitis \& cough. } \\
\hline Alstonia scholaris (L.) R. Br. & Apocynaceae & Thumriat & Tree & LR & B,La,R \\
\hline \multicolumn{6}{|c|}{$\begin{array}{l}50 \mathrm{ml} \text { of R-B decoction is taken three times daily in for hypertension. The milky juice or La is applied on cuts \& } \\
\text { wounds. The La with an equal proportion of mustard oil is used as an eardrop for ear-aches. }\end{array}$} \\
\hline Amaranthus spinosus L. & Amaranthaceae & Thuamriat & Herb & LR & $R, L$ \\
\hline \multicolumn{6}{|c|}{$\begin{array}{l}R \text { extract is drunk for the remedy of hemorrhages. } L \text { are boiled in water \& drunk to treat difficult urination. Juice of } \\
\text { crushed } L \text { are used as a hemostatic. }\end{array}$} \\
\hline Amomum dealbatum Roxb. & Zingiberaceae & Aidu & Herb & LR & $B, R$ \\
\hline \multicolumn{6}{|c|}{ The $B$ is crushed \& the juice is used as antiseptic. A decoction of $R$ suckers is taken for hypertension. } \\
\hline $\begin{array}{l}\text { Amorphophallus paeoniifolius } \\
\text { (Dennst.) Nicolson }\end{array}$ & Araceae & Telhawng & Herb & LR & $\mathrm{T}$ \\
\hline \multicolumn{6}{|c|}{ The $\mathrm{T}$ is sliced into pieces \& boiled in water to remove the irritants. } \\
\hline Ampelocissus latifolia (Roxb.) Planch. & Vitaceae & Heruipawl & Climber & LR & $L, R$ \\
\hline \multicolumn{6}{|c|}{$\begin{array}{l}\text { Juice of crushed } \mathrm{R} \text { is taken orally to stop excess urination mixed with blood. The } \mathrm{L} \text { are chewed against teeth set on } \\
\text { edge. }\end{array}$} \\
\hline Ananas comosus (L.) Merr. & Bromeliaceae & Lakhuihthei & Herb & LR & $\mathrm{Fr}, \mathrm{L}$ \\
\hline \multicolumn{6}{|c|}{ The $L$ or Fr are crushed \& the juice is used for the remedy of convulsions. } \\
\hline $\begin{array}{l}\text { Andrographis paniculata (Burm.f.) } \\
\text { Wall. ex. Nees }\end{array}$ & Acanthaceae & Hnahkhapui & Herb & NT & $\begin{array}{l}\text { L,St, } \\
\text { WP }\end{array}$ \\
\hline \multicolumn{6}{|c|}{$\begin{array}{l}L \text { are antispasmodic, used to treat diarrhea, and loss of appetite in infants. } R \& L \text { are used as a febrifuge, for treatment } \\
\text { of stomach ache and used as an antihelminthic. WP in jaundice. }\end{array}$} \\
\hline Angiopteris evecta (G. Forst.) Hoffm. & Marattiaceae & Arthladawnpui & $\begin{array}{l}\text { Terrestrial } \\
\text { fern }\end{array}$ & LR & $\mathrm{R}$ \\
\hline \multicolumn{6}{|l|}{ A R paste is used to treat bone fractures. } \\
\hline Anacardium occidentale L. & Anacardiaceae & Sazupumpui-thei & Tree & EW/VU & $\mathrm{B}$ \\
\hline \multicolumn{6}{|c|}{ Juice of crushed B is applied externally on ring worm, leprosy \& warts. } \\
\hline Anacolosa crassipes Kurz & Olacaceae & Lushai-nautur & Shrub & LR & $\mathrm{L}$ \\
\hline \multicolumn{6}{|c|}{ Boiled $L$ are used with water for bathing children to treat measles \& skin eruptions. } \\
\hline $\begin{array}{l}\text { Anogeissus acuminata (Roxb. ex DC.) } \\
\text { Guill., Perr. \& A. Rich. }\end{array}$ & Combretaceae & Zairum & Tree & LR & B \\
\hline \multicolumn{6}{|c|}{ The $B$ is crushed \& the juice is used as a remedy for diarrhoea \& beriberi. } \\
\hline $\begin{array}{l}\text { Anthocephalus chinensis (Lam.) Rich. } \\
\text { ex Walp. }\end{array}$ & Rubiaceae & Banphar & Tree & LR & $\mathrm{B}, \mathrm{L}$ \\
\hline \multicolumn{6}{|c|}{ B\&L are used for the remedy of uterine complaints \& blood diseases. } \\
\hline $\begin{array}{l}\text { Aporosa octandra (Buch.-Ham. ex D. } \\
\text { Don) Vickery }\end{array}$ & Phyllanthaceae & Chhawntual & Small tree & LR & B \\
\hline \multicolumn{6}{|c|}{$50 \mathrm{ml}$. of B decoction is taken for the remedy of stomach ache \& stomach ulcer. } \\
\hline Aquilaria malaccensis Lam. & Thymeleaceae & Thingrai & Small Tree & CR: E & $\mathrm{Re}, \mathrm{W}$ \\
\hline
\end{tabular}




\section{Rai \& Lalramnghinglova - Ethnomedicinal Plants of India with Special Reference to an Indo-Burma Hotspot Region: An overview}

\begin{tabular}{|c|c|c|c|c|c|}
\hline Scientific name & Family & Local name & Habit & Status & $\begin{array}{l}\text { Part } \\
\text { Used }\end{array}$ \\
\hline \multicolumn{6}{|l|}{ Mode of Utilization/Uses } \\
\hline \multicolumn{6}{|c|}{$\begin{array}{l}\text { The } \mathrm{W} \text { is used as a stimulant, antiasthmatic, antidiarrheal, antirheumatism, astringent, carminative diuretic, brain } \\
\text { tonic, leucoderma, and for stomach problems and diseases of the eyes, ears \& skin. }\end{array}$} \\
\hline Ardisia colorata Link & Primulaceae & Hnunthlum & Small tree & LR & $\mathrm{R}$ \\
\hline \multicolumn{6}{|c|}{ The R paste is applied externally on chronic ulcer. } \\
\hline Ardisia paniculata Roxb. & Primulaceae & Naunuar & Small tree & LR & $\mathrm{R}$ \\
\hline \multicolumn{6}{|c|}{$\begin{array}{l}\text { Decoction of } \mathrm{R} \text { is used for rheumatism. Crushed } \mathrm{R} \text { in combination with Smilax ovalifolia Roxb. \& Bridelia tomentosa } \\
\text { Blume is boiled with water \& taken for jaundice. }\end{array}$} \\
\hline Ardisia polycephala Wall. ex A. DC. & Primulaceae & Sialtuai & Small tree & VU & $\mathrm{R}$ \\
\hline \multicolumn{6}{|c|}{$\begin{array}{l}\text { The } \mathrm{R} \text { with that of Amaranthus caudata } \mathrm{L} \text {. is crushed \& taken with cold water to stop excess bleeding \& with warm } \\
\text { water for normal bleeding after child birth. }\end{array}$} \\
\hline Arenga pinnata (Wurmb) Merr. & Arecaceae & Thangtung & Shrub & LR & $\mathrm{R}$ \\
\hline \multicolumn{6}{|c|}{ Decoction of $\mathrm{R}$ is applied for bronchitis \& stomach ache. } \\
\hline Areca catechu L. & Arecaceae & Kuhva & Palm tree & LR & Fr,L \\
\hline \multicolumn{6}{|c|}{$\begin{array}{l}\text { The Fr/nut is antihelminthic, astringent, and used for urinary disorders. Young } L \text { are astringent and applied for the } \\
\text { remedy of bleeding gums, as well as for checking pyrosis of pregnancy \& watery vaginal discharges. }\end{array}$} \\
\hline Arenga saccharifera Labill. & Arecaceae & Thangtung & Palm tree & LR & $\mathrm{R}$ \\
\hline \multicolumn{6}{|c|}{$\mathrm{R}$ is used to treat stomach ache \& bronchitis. } \\
\hline Artemisia indica Wild. & Asteraceae & Sai & Herb & VU & $\mathrm{L}$ \\
\hline \multicolumn{6}{|c|}{ Infusion of $L$ taken orally for the remedy of fever, stomach ache, whooping cough, bleeding from the nose \& gum. } \\
\hline Artocarpus chama Buch.-Ham. & Moraceae & Tatkawng & Tree & LR & $\mathrm{B}$ \\
\hline \multicolumn{6}{|c|}{ Decoction of $B$ is taken for the remedy of diarrhoea. A paste of $B$ is applied externally on sores \& pimples. } \\
\hline Artocarpus lakoocha Wall. ex Roxb. & Moraceae & Theitat & Tree & LR & $\mathrm{B}, \mathrm{S}$ \\
\hline \multicolumn{6}{|c|}{$\begin{array}{l}\text { The S is used as a purgative \& B powder is applied to sores to draw out purulent matter. An infusion is applied to } \\
\text { pimples \& cracked skin. }\end{array}$} \\
\hline Asparagus racemosus Wild. & Asparagaceae & Arkebawk. Satavar & Herb & NT & $\mathrm{R}, \mathrm{L}$ \\
\hline \multicolumn{6}{|c|}{$\begin{array}{l}\mathrm{R} \text { are used as a refrigerant, demulcent, diuretic, aphrodisiac, antiseptic, alternative, antidiarrheal, antidysenteric } \\
\& \text { used in fever, rheumatism \& as a sexual tonic. A decoction of } R \text { is given for fever \& as an extract to treat fungal } \\
\text { infections. Boiled } L \text { are applied on boils \& small pox. }\end{array}$} \\
\hline Averrhoa sp. & Oxalidaceae & Theiherawt & Small tree & NT & Fr,L \\
\hline \multicolumn{6}{|c|}{$\begin{array}{l}\text { Three or four slices of Fr are take daily for jaundice, bleeding piles, \& as an antiscorbutic. An infusion of } L \text { are taken } \\
\text { to treat an enlargement of the liver. }\end{array}$} \\
\hline Azadirachta indica A. Juss. & Meliaceae & Nimthing & Tree & NT & WP \\
\hline \multicolumn{6}{|c|}{$\begin{array}{l}\text { Stem } B \text { is used as an astringent for skin diseases. } R \text { B is used to prevent the periodic return of diseases. } L \text { are used } \\
\text { as antiseptic, antibiotic, in boils, ulcer \& eczema. F is used to treat stomach aches, with the berry used as a purgative, } \\
\text { antihelminthic, and gum demulcent. S oil in used in rheumatism \& skin diseases. }\end{array}$} \\
\hline Baccaurea ramiflora Lour. & Phyllanthaceae & & Tree & LR & $B, L$ \\
\hline \multicolumn{6}{|c|}{$\begin{array}{l}\text { Purgative, used in stomach ache, juice of coat of inner } B \text { is taken against food allergy as well as antihelminthic. } 2-3 \\
\text { young } L \text { are chewed } 3 \text { times a day for toothache. }\end{array}$} \\
\hline Bauhinia variegata $\mathrm{L}$. & Fabaceae & Vaube & Tree & LR & $\mathrm{B}, \mathrm{FI}$ \\
\hline \multicolumn{6}{|c|}{$\begin{array}{l}\mathrm{B} \text { is used as a carminative, tonic, astringent, antidiarrheal, blood purifier, and for treatment of goiters. } \mathrm{F} \text { is used as a } \\
\text { laxative. }\end{array}$} \\
\hline Begonia inflata C.B. Clarke & Begoniaceae & Sekhupthur-hmul & Herb & NT & WP \\
\hline
\end{tabular}




\begin{tabular}{|l|l|l|l|l|l|l|}
\hline Scientific name & Family & Local name & Habit & Status & $\begin{array}{l}\text { Part } \\
\text { Used }\end{array}$ \\
\hline Mode of Utilization/Uses & Cucurbitaceae & Maipawl & $\begin{array}{l}\text { Climbing } \\
\text { herb }\end{array}$ & NT & Fr,S \\
\hline Benincasa hispida (Thunb.) Cogn. & &
\end{tabular}

$\mathrm{Fr}$ is used as a laxative, diuretic, antiperiodic and for treatment of internal organ hemorrhages. $\mathrm{S}$ are used as antihelminthics.

\begin{tabular}{|l|l|l|l|l|l|}
\hline Bergenia ciliata (Haw.) Sternb. & Saxifragaceae & Pan-damdawi & Herb & EN & Ls,R \\
\hline
\end{tabular}

$L$ are used for ear ache. $L \& R$ as used as a tonic \& antiscorbent, \& to treat diarrhoea, fevers, piles \& urinary problems.

\begin{tabular}{|l|l|l|l|l|l|}
\hline Bidens pilosa L. & Asteraceae & Vawkpuithal & Herb & LR: W & F,L,Sh \\
\hline
\end{tabular}

Young Sh are used to treat rheumatism. $\mathrm{L}$ are used for eye \& ear complaints. $\mathrm{F}$ is used as an antidiarrheal.

\begin{tabular}{|l|l|l|l|l|l|}
\hline Bischofia javanica Blume & Phyllanthaceae & Khuangthli & Tree & LR & B,L,Sh \\
\hline
\end{tabular}

Young Ls \& buds are used in tonsillitis \& for throat pain. An infusion of young Sh \& $L$ are taken orally for diphtheria \& phryngitis. A decoction of the $B$ is taken internally for cholera.

\begin{tabular}{|l|l|l|l|l|l|}
\hline Blumea laciniata (Roxb.) DC. & Asteraceae & Khuanglawr & Herb & LR & L,R \\
\hline
\end{tabular}

A paste from $R$ is used against snake bite. $L$ are crushed $\&$ the juice is applied externally on the bitten part.

\begin{tabular}{|l|l|l|l|l|l|l} 
Blumea lanceolaria (Roxb.) Druce & Asteraceae & Buarze & Shrub & VU & L
\end{tabular}

Pressed juice of $L$ are applied to treat wounds \& chronic ulcers. An infusion of $L$ are taken against dysentery.

\begin{tabular}{|l|l|l|l|l|l}
\hline Bombax ceiba L. & Malvaceae & Phunchawng & Tree & VU & $\begin{array}{l}\text { B,G, } \\
\text { Fr, R }\end{array}$
\end{tabular}

The $\mathrm{R}$ is used as a stimulant \& tonic. B is used as an emetic. $\mathrm{G}$ is used as an aphrodisiac, demulcent, homeostatic astringent, \& tonic (alternatively used for the remedy of diarrhoea \& dysentery). Fr \& F are used against snake bite.

\begin{tabular}{|l|l|l|l|l|l|}
\hline Bombax insigne Wall. & Malvaceae & Pang & Tree & LR & B
\end{tabular}

The $\mathrm{B}$ is boiled with that of Mangifera indica $\mathrm{L}$. (equal part) \& a half cup of water is taken twice daily for the remedy of tonsillitis \& other throat infections.

\begin{tabular}{|l|l|l|l|l|l|}
\hline Buddleja asiatica Lour. & Scrophulariaceae & Serial & $\begin{array}{l}\text { Shrub/ } \\
\text { small tree }\end{array}$ & NT & F \\
\hline F is used to treat skin diseases. & Lamiaceae & Hnahkiah & Tree & LR & B \\
\hline Callicarpa arborea Roxb.
\end{tabular}

The $B$ is crushed \& the juice is drunk for the remedy of stomach pain, dysentery \& vomiting. Juice of the inner B coat is used as a hemostatic on cuts.

\begin{tabular}{|c|c|c|c|c|c|}
\hline Callicarpa macrophylla Vahl & Lamiaceae & Hnahkiahte JHR. & Small Tree & LR & Ls \\
\hline \multicolumn{6}{|c|}{$L$ are turned into paste $\&$ applied on bone fractures. } \\
\hline Calotropis gigantea (L.) W.T. Aiton & Apocynaceae & Madar & Shrub & EW/VU & $\begin{array}{l}\text { L,Sa, } \\
\text { St }\end{array}$ \\
\hline \multicolumn{6}{|l|}{ Used for wound healing. } \\
\hline Camellia sinensis (L.) Kuntze & Theaceae & Thingpui & Small tree & LR & $\mathrm{L}$ \\
\hline \multicolumn{6}{|c|}{ Tea from boiled $\mathrm{L}$ are used as an astringent, stimulant $\&$ diuretic. } \\
\hline Canarium strictum Roxb. & Burseraceae & Berawthing & Tree & NT & B \\
\hline \multicolumn{6}{|l|}{$B$ is used to treat rashes. } \\
\hline Canavalia ensiformis (L.) DC. & Fabaceae & Fangra & Climber & LR & S \\
\hline \multicolumn{6}{|c|}{ Sliced $S$ is applied to snake bite to draw out the poison. } \\
\hline Carica papaya L. & Caricaceae & Thingfanghma & Small tree & LR & $\mathrm{Fr}, \mathrm{S}$ \\
\hline
\end{tabular}




\section{Rai \& Lalramnghinglova - Ethnomedicinal Plants of India with Special Reference to an Indo-Burma Hotspot Region: An overview}

\begin{tabular}{|c|c|c|c|c|c|}
\hline Scientific name & Family & Local name & Habit & Status & $\begin{array}{l}\text { Part } \\
\text { Used }\end{array}$ \\
\hline \multicolumn{6}{|l|}{ Mode of Utilization/Uses } \\
\hline Caryota urens L. & Arecaceae & Tum & Palm tree & LR & St \\
\hline \multicolumn{6}{|c|}{ A flesh toddy from the St is used as food during famine. } \\
\hline Cassia alata L. & Fabaceae & Tuihlo & Shrub & LR & $\mathrm{L}$ \\
\hline \multicolumn{6}{|c|}{ The $L$ are bruised \& applied to ringworm (fungal) infections as well as to other skin infections. } \\
\hline Cassia fistula L. & Fabaceae & Ngaingaw & Tree & LR & WP \\
\hline \multicolumn{6}{|c|}{ R, B, S \& L are used as purgatives, tonics \& febrifuges. } \\
\hline Cassia hirsuta L. & Fabaceae & Sab-daru & Shrub & CR/VU & $L, R$ \\
\hline \multicolumn{6}{|c|}{ In case of snake-bite juice of $R$ taken internally while brushed $L$ applied externally on affected part } \\
\hline Cassia tora L. & Fabaceae & Kelbe-an & Shrub & LR & $L, R, S$ \\
\hline \multicolumn{6}{|c|}{$R$ paste is used externally against ringworm infections. A decoction of L/S is applied externally on cutaneous diseases. } \\
\hline Catharanthus roseus (L.) G. Don & Apocynaceae & Kumtluang & Herb & LR/IN & L,R,St \\
\hline \multicolumn{6}{|c|}{$\begin{array}{l}\text { The raw } L \text { are taken treat high blood pressure. } L \text { are used as an anti-cancer agent. A decoction of } R, S t \& L \text { are used } \\
\text { for diabetes, diarrhoea, dysentery, \& cholera. }\end{array}$} \\
\hline $\begin{array}{l}\text { Caulokaempferia linearis (Wall.) } \\
\text { K. Larsen }\end{array}$ & Zingiberaceae & $\begin{array}{l}\text { Lung-ai-thing } \\
\text { Lalram }\end{array}$ & Herb & LR & L \\
\hline \multicolumn{6}{|c|}{ Chakmas apply crushed $L$ on the head to treat vertigo. } \\
\hline Cautleya gracilis (Sm.) D\&y & Zingiberaceae & Pale & Herb & C/EW & Rh \\
\hline \multicolumn{6}{|c|}{$\begin{array}{l}\text { An infusion of } \mathrm{Rh} \text { is taken for flatulence, colic \& hepatomegaly. The } \mathrm{Rh} \text { is eaten raw to relieve colic, cough, \& stomach } \\
\text { heat. }\end{array}$} \\
\hline Centella asiatica (L.) Urb. & Apiaceae & Lambak/Hnahbi-al & Herb & LR & L \\
\hline \multicolumn{6}{|c|}{$\begin{array}{l}L \text { are used as a memory stimulator and to treat hypertension. The } L \text { are boiled } \& \text { the water is taken for the remedy of } \\
\text { asthma \& eye problems. }\end{array}$} \\
\hline Cephalostachyum capitatum Munro & Poaceae & Raw-ngal & Herb & LR & L \\
\hline \multicolumn{6}{|c|}{$\mathrm{L}$ are used as a tonic, antihelminthic, carminative $\&$ to treat stomach ache. } \\
\hline Chassalia ophioxyloides (Wall.) Craib & Rubiaceae & Khummurmu & Shrub & LR & $\mathrm{R}$ \\
\hline \multicolumn{6}{|c|}{ The R paste is applied externally to chronic ulcers, tumors \& sores. } \\
\hline Chonemorpha fragrans (Moon.) Alston & Apocynaceae & Phungthe ikelki & Climber & LR & $\mathrm{R}$ \\
\hline \multicolumn{6}{|c|}{$100 \mathrm{ml}$ of $\mathrm{R}$ infusion is applied internally (vaginally) twice daily to retain the placenta. } \\
\hline $\begin{array}{l}\text { Chromolaena odorata (L.) R.M. King \& } \\
\text { H. Rob. }\end{array}$ & Asteraceae & Tlangsam & Shrub & LR & $\mathrm{L}$ \\
\hline \multicolumn{6}{|c|}{ Crushed L juice is applied externally as to stop bleeding. } \\
\hline Chukrasia tabularis A. Juss. & Meliaceae & Zawngtei & Tree & LR & $\mathrm{R}, \mathrm{SC}$ \\
\hline \multicolumn{6}{|c|}{$\begin{array}{l}\text { Raw } R \text { are taken for the remedy of stomach pain. An infusion of S-coats is taken internally or a small portion is eaten } \\
\text { raw to remedy diarrhoea \& dysentery. }\end{array}$} \\
\hline $\begin{array}{lll}\text { Cinnamomum obtusifolium (Roxb.) } \\
\text { Nees }\end{array}$ & Lauraceae & Thakthingsuak & Tree & LR & B \\
\hline \multicolumn{6}{|c|}{ B is used to remedy dyspepsia \& liver complaints. } \\
\hline $\begin{array}{l}\text { Cinnamomum tamala (Buch-Ham.) } \\
\text { Nees \& Eberm. }\end{array}$ & Lauraceae & Tejpatta & Tree & LR & $B, L$ \\
\hline \multicolumn{6}{|c|}{$\mathrm{L}$ are used as a stimulant, carminative, antirheumatic, \& antidiarrheal. B is used in treating gonorrhoea. } \\
\hline Cinnamomum verum J. Presl & Lauraceae & Thakthing & Tree & LR & $B, L$ \\
\hline
\end{tabular}




\begin{tabular}{|c|c|c|c|c|c|}
\hline Scientific name & Family & Local name & Habit & Status & $\begin{array}{l}\text { Part } \\
\text { Used }\end{array}$ \\
\hline \multicolumn{6}{|l|}{ Mode of Utilization/Uses } \\
\hline Cissus repanda Vahl. & Vitaceae & Vawmdawng & Climber & LR & $L, R$ \\
\hline \multicolumn{6}{|c|}{ A R paste in water mixed with Murraya koenigii (L.) Spreng. is drunk as a tea for heartburn. $L$ are used for snake bite } \\
\hline Cissus discolor Blume & Vitaceae & Sangharhmai & Climber & NT & $L, R, S t$ \\
\hline \multicolumn{6}{|c|}{ A decoction of the R, St $\& L$ is used for inflamed kidneys. } \\
\hline Citrus sinensis (L.) Osbeck & Rutaceae & Serthlum & Tree & LR & L \\
\hline \multicolumn{6}{|c|}{ The $L$ are boiled \& the water is taken for the remedy of malaria. } \\
\hline Claoxylon khasianum Hook.f. & Euphorbiaceae & Nagabang & $\begin{array}{l}\text { Shrub/ } \\
\text { small tree }\end{array}$ & NT & $R$ \\
\hline \multicolumn{6}{|c|}{ A R paste is applied externally for tumors/cancer. } \\
\hline $\begin{array}{l}\text { Clerodendrum bracteatum Wall. } \\
\text { ex Walp. }\end{array}$ & Verbenaceae & Phuihnam & Small tree & LR & $L, R$ \\
\hline \multicolumn{6}{|l|}{ The $L \& R$ are used to remedy diarrhoea. } \\
\hline Clerodendrum colebrookianum Walp. & Verbenaceae & Phuihnam & Small tree & VU & $\mathrm{L}$ \\
\hline \multicolumn{6}{|c|}{$50 \mathrm{ml}$ of a decoction of $\mathrm{L}$ is taken twice daily to treat hypertension. } \\
\hline $\begin{array}{l}\text { Colysis hemionitidea (Wall. ex C. Presl) } \\
\text { C. Presl }\end{array}$ & Polypodiaceae & Kawkte-bet ${ }^{\star}$ & Fern & LR & $\mathrm{Rh}$ \\
\hline \multicolumn{6}{|c|}{ The Rh is used for the treatment of bone fractures. } \\
\hline Congea tomentosa Roxb. & Verbenaceae & Sahuaihrui & Shrub & NT & St \\
\hline \multicolumn{6}{|l|}{ St is used to treat animal wounds. } \\
\hline Cordia dichotoma G. Forst. & Boraginaceae & Muk & WP parts & LR & $\mathrm{B}, \mathrm{Fr}, \mathrm{L}$ \\
\hline \multicolumn{6}{|c|}{$\begin{array}{l}\text { The plant is used as an antidote for snake bite. Fr is used as an astringent, antihelminthic, demulcent, expectorant, } 8 \\
\text { for treatment of urinary infections. B is used as a febrifuge. L are used to remedy ulcers, cough \& colds. }\end{array}$} \\
\hline Costus speciosus (J. König) Sm. & Costaceae & Sumbul & Herb & LR & $\mathrm{L}, \mathrm{R}, \mathrm{Rh}$ \\
\hline \multicolumn{6}{|c|}{$\begin{array}{l}\text { A cold infusion of the Rh is taken orally for kidney problem } \& \text { leprosy. Crushed } R \text { juice is taken internally for the } \\
\text { removal kidney/gall bladder stones. The } L \text { are boiled } \& \text { the water is taken for the remedy of tonsillitis. }\end{array}$} \\
\hline Crotalaria juncea L. & Fabaceae & Tumthang & Shrub & LR & $\mathrm{L}$ \\
\hline \multicolumn{6}{|c|}{$L$ are used as a demulcent, emetic, purgative $\&$ abortifacient. } \\
\hline Cucurbita maxima Duchesne & Cucurbitaceae & Mai & Climber & LR & $\mathrm{Fr}, \mathrm{L}$ \\
\hline \multicolumn{6}{|c|}{ The Fr or $L$ are boiled \& the water is taken for the remedy of eye problem. } \\
\hline Curculigo crassifolia (Baker) Hook. f. & Hypoxidaceae & Phaiphek & Herb & LR & IS,T \\
\hline \multicolumn{6}{|c|}{$\begin{array}{l}\text { Tuber/immature stem juice is used in stomach ache \& also applied on deep cuts \& bandaged to relieve pain \& to hea } \\
\text { wounds. }\end{array}$} \\
\hline Curcuma caesia Roxb. & Zingiberaceae & Ailaidum & Herb & $\mathrm{NT} / \mathrm{C}$ & $\mathrm{Rh}$ \\
\hline \multicolumn{6}{|c|}{ Crushed Rh juice is used for the treatment of diarrhoea \& stomach pain. } \\
\hline Curcuma longa L. & Zingiberaceae & Aieng & Herb & $A / C$ & $\mathrm{Rh}$ \\
\hline \multicolumn{6}{|l|}{ Crushed Rh juice is used as an antiseptic. } \\
\hline $\begin{array}{l}\text { Curcumorpha longiflora (Wall.) } \\
\text { A.S. Rao \& D.M. Verma }\end{array}$ & Zingiberaceae & Ailaidum & Herb & EW/VU & Rh \\
\hline \multicolumn{6}{|c|}{ A Rh infusion is taken to remedy dysentery \& diarrhoea. } \\
\hline Cyathula prostrata (L.) Blume & Amaranthaceae & $\begin{array}{l}\text { Buchhawlsen } \\
\text { Lalram }\end{array}$ & Herb & LR & $\mathrm{L}$ \\
\hline
\end{tabular}




\section{Rai \& Lalramnghinglova - Ethnomedicinal Plants of India with Special Reference to an Indo-Burma Hotspot Region: An overview}

\begin{tabular}{|c|c|c|c|c|c|}
\hline Scientific name & Family & Local name & Habit & Status & $\begin{array}{l}\text { Part } \\
\text { Used }\end{array}$ \\
\hline \multicolumn{6}{|l|}{ Mode of Utilization/Uses } \\
\hline Cyclea peltata Hook. f. \& Thomson & Menispermaceae & Khauchhim & Climber & VU/NT & $\mathrm{R}$ \\
\hline \multicolumn{6}{|c|}{ A R decoction is taken orally for colic, fever \& diarrhoea. } \\
\hline Cynodon dactylon (L.) Pers. & Poaceae & Phaitual & $\begin{array}{l}\text { Perennial } \\
\text { grass: on } \\
\text { roadsides: } \\
\text { to } 1,800 \mathrm{~m}\end{array}$ & LR & WP \\
\hline \multicolumn{6}{|c|}{ Bruised plant is inhaled for treatment of a toothache. } \\
\hline Dalbergia pinnata (Lour.) Prain & Fabaceae & Tengterehrui & Tree & CR/VU & $B, R$ \\
\hline \multicolumn{6}{|c|}{ B \& R are used to treat stomach problems, hepatitis \& toothache. } \\
\hline $\begin{array}{l}\text { Datura suaveolens Humb. \& Bonpl. ex } \\
\text { Willd. }\end{array}$ & Solanaceae & Tawtawrawt par & $\begin{array}{l}\text { Shrub: } \\
\text { Cultivated } \\
\text { especially } \\
\text { in home } \\
\text { garden } \\
\end{array}$ & LR & $\mathrm{L}$ \\
\hline \multicolumn{6}{|c|}{$\begin{array}{l}\mathrm{L} \text { are dried \& smoked as tobacco for chest complaints, asthma. Roasted } L \text { are applied externally to treat breast lumps/ } \\
\text { stony hard breasts. }\end{array}$} \\
\hline Dendrocnide sinuata (Blume) Chew & Urticaceae & Thakpui & Shrub & LR & $R$ \\
\hline \multicolumn{6}{|c|}{ The $\mathrm{R}$ are boiled along with crabs \& the water is taken for the remedy of jaundice. } \\
\hline Dendrobium denudans D. Don & Orchidaceae & Naubanhlosen & $\begin{array}{l}\text { Orchid/ } \\
\text { Shrub }\end{array}$ & EN/VU & St \\
\hline \multicolumn{6}{|l|}{ The St are used as a narcotic. } \\
\hline $\begin{array}{l}\text { Desmodium gyroides (Roxb. ex Link) } \\
\text { DC. }\end{array}$ & Fabaceae & Kerangkana & Shrub & LR & $\mathrm{R}$ \\
\hline \multicolumn{6}{|c|}{ A R paste is used as a treatment for inflammatory glands. } \\
\hline Desmodium triflorum (L.) DC. & Fabaceae & $\begin{array}{l}\text { Bawngkek- } \\
\text { hlo Lalram }\end{array}$ & Herb & LR & WP \\
\hline \multicolumn{6}{|c|}{ The plants are boiled $\&$ the water is taken for kidney problem $\&$ urinal problems. Fresh $L$ juice is applied on wounds } \\
\hline Desmos chinensis Lour. & \multirow[t]{2}{*}{ Annonaceae } & \multirow[t]{2}{*}{ Zunin -damdawi } & \multirow{2}{*}{$\begin{array}{l}\text { Scandent } \\
\text { scrub }\end{array}$} & \multirow[t]{2}{*}{ LR } & \multirow[t]{2}{*}{$L, R$} \\
\hline $\begin{array}{l}\text { Desmos dumosus (Roxb.) Saff. } \\
\text { (Used alone \& in combination) }\end{array}$ & & & & & \\
\hline \multicolumn{6}{|c|}{ A R decoction is used for treatment of painful urination. } \\
\hline Desmos longiflorus Saff. & Annonaceae & Chi-ri-pi & Small tree & NT & $L, R$ \\
\hline \multicolumn{6}{|c|}{ A R paste is used for the treatment of chronic ulcer. A L decoction is used to treat asthma. } \\
\hline Dillenia indica L. & Dilleniaceae & Kawrthindeng & Tree & LR & $\mathrm{B}, \mathrm{Fr}$ \\
\hline \multicolumn{6}{|c|}{$\begin{array}{l}\text { The Fr is boiled \& the water is taken for the remedy of jaundice. } 50 \mathrm{ml} \text { of B infusion is taken twice daily for treatment } \\
\text { of diarrhoea \& dysentery. }\end{array}$} \\
\hline Dillenia pentagyna Roxb. & Dilleniaceae & Kaihzawl & Tree & LR & $\mathrm{B}, \mathrm{W}$ \\
\hline \multicolumn{6}{|c|}{$\begin{array}{l}\text { A B decoction is taken orally for diabetes,. A B paste is applied externally on rheumatic pains. W used for anticancer } \\
\& \text { antiulcer agents. }\end{array}$} \\
\hline $\begin{array}{l}\text { Dinochloa compactiflora (Kurz.) } \\
\text { McClure }\end{array}$ & Poaceae & Sairil & Bamboo & LR & St \\
\hline \multicolumn{6}{|c|}{$\begin{array}{l}\text { The outer St epidermis is scraped off \& applied externally on cuts to stop bleeding. Sap oozing out of the cut stem is } \\
\text { given to children for influenza, cough \& chest complaints. }\end{array}$} \\
\hline Diplazium maximum (D. Don) C. Chr. & Woodsiaceae & Chakawk-ei-chi & Fern & LR & $\mathrm{R}$ \\
\hline
\end{tabular}




\begin{tabular}{|c|c|c|c|c|c|}
\hline Scientific name & Family & Local name & Habit & Status & $\begin{array}{l}\text { Part } \\
\text { Used }\end{array}$ \\
\hline \multicolumn{6}{|l|}{ Mode of Utilization/Uses } \\
\hline \multicolumn{6}{|c|}{ The $\mathrm{R}$ is crushed, combined with other plants, \& the mixture is applied externally on bone fractures. } \\
\hline Dioscorea alata L. & Dioscoreaceae & Rambachim & Climber & LR & $\mathrm{T}$ \\
\hline \multicolumn{6}{|c|}{ The $\mathrm{T}$ is used for treatment of leprosy, piles \& gonorrhoea. } \\
\hline Dipterocarpus turbinatus Gaertn. & Dipterocarpaceae & Lawngthing & Tree & LR & $\begin{array}{l}\text { Re, } \\
\text { St, W }\end{array}$ \\
\hline \multicolumn{6}{|c|}{ Re is used as a stimulant \& diuretic, \& to treat gonorrhoea, chronic bronchitis \& leprosy. } \\
\hline Dracaena spicata Roxb. & Asparagaceae & Phunhring & Shrub & LR & $L, R$ \\
\hline \multicolumn{6}{|l|}{ The $L \& R$ are used to treat stomach ache. } \\
\hline $\begin{array}{l}\text { Drymaria cordata (L.) Willd. ex Roem. } \\
\text { \& Schult. }\end{array}$ & Caryophyllaceae & Changkalrit & Herb & LR & WP \\
\hline \multicolumn{6}{|c|}{$\begin{array}{l}\text { The WP is boiled \& the steam is inhaled to treat sinus problems \& cough. Bruised } L \text { are used as lotion for joint pair } \\
\& \text { muscle strain. }\end{array}$} \\
\hline Dysoxylum gobara (Buch.-Ham.) Merr. & Meliaceae & Thingthupui & Tree & LR & $\mathrm{Bu}, \mathrm{L}$ \\
\hline \multicolumn{6}{|c|}{ A decoction of $L \&$ buds is used as a remedy for diarrhoea \& dysentery. } \\
\hline Elaeagnus caudata Schltdl. ex Momiy. & Elaeagnaceae & Sarzukpui & $\begin{array}{l}\text { Scandent } \\
\text { herb }\end{array}$ & LR & $L, R$ \\
\hline
\end{tabular}

The $\mathrm{R}$ is boiled \& the water is taken orally for against retained the placenta. Crushed $\mathrm{R}$ juice is taken for easy labor \& as a treatment after child birth. A L infusion is taken orally to strengthen uterus function after child birth.

\begin{tabular}{|l|l|l|l|l|l}
\hline Elaeagnus pyriformis Hook.f. & Elaeagnaceae & Ramsarzuk & Shrub & VU & $R$ \\
\hline
\end{tabular}

$\mathrm{R}$ paste is dipped in water \& drunk to treat appendicitis.

\begin{tabular}{|l|l|l|l|l|l|}
\hline Elsholtzia blanda (Benth.) Benth. & Lamiaceae & Nauhri & Shrub & NT & A \\
\hline
\end{tabular}

An A infusion is used for children's disease called nauhri, a combination of fever, cholera, skin diseases \& inflammation. A $L$ poultice is used to treat inflammatory glands.

\begin{tabular}{|l|l|l|l|l|l|}
\hline Elsholtzia ciliata (Thunb.) Hyl. & Lamiaceae & $\begin{array}{l}\text { Ram-lengser } \\
\text { Lalram }\end{array}$ & Herb & LR & WP \\
\hline
\end{tabular}

$\mathrm{L}$ juice is used as a diuretic, and for treatment of cough \& colds.

\begin{tabular}{|l|l|l|l|l|l|}
\hline $\begin{array}{l}\text { Embelia subcoriacea (C.B. Clarke) } \\
\text { Mez }\end{array}$ & Elaeagnaceae & Tling & Climber & LR & L \\
\hline
\end{tabular}

$A L$ decoction is used for bathing in the treatment of small pox \& for bathing woman's injuries after child birth.

\begin{tabular}{|c|c|c|c|c|c|}
\hline Emblica officinalis Gaertn. & Euphorbiaceae & Sunhlu & Tree & LR & $\mathrm{Fr}$ \\
\hline \multicolumn{6}{|c|}{ The raw Fr is taken for the remedy of stomach problems. } \\
\hline Entada pursaetha DC. & Fabaceae & Kawi & Climber & LR & $\mathrm{S}$ \\
\hline \multicolumn{6}{|c|}{ The S are soaked in water \& the water is dropped into the nostrils for treatment of leeches. } \\
\hline Ervatamia coronaria (Jacq.) Stapf & Apocynaceae & Pararsi & Shrub & LR & $B, L, R$ \\
\hline
\end{tabular}

The $\mathrm{R}$ are used to provide comfort for toothaches. $\mathrm{R} \& \mathrm{~B}$ used as an antidote for scorpion stings. Milky juice is used to treat diseases of eyes.

\begin{tabular}{|c|c|c|c|c|c|}
\hline Eryngium foetidum $\mathrm{L}$. & Apiaceae & Bahkhawr & Herb & LR & $\mathrm{R}$ \\
\hline \multicolumn{6}{|c|}{ The $\mathrm{R}$ are used for treatment of stomach ache. } \\
\hline Erythrina stricta Roxb. & Fabaceae & Fartuahpui & Tree & LR & $\mathrm{B}$ \\
\hline
\end{tabular}

The $\mathrm{B}$ is used as an astringent $\&$ antidote to snake bite. An inner B coating decoction is taken orally to treat stomach ulcer.

\begin{tabular}{|l|l|l|l|l|l|}
\hline Eucalyptus globulus Labill. & Myrtaceae & Eucalyptus & Tree & LR & Ch,L \\
\hline
\end{tabular}




\section{Rai \& Lalramnghinglova - Ethnomedicinal Plants of India with Special Reference to an Indo-Burma Hotspot Region: An overview}

\begin{tabular}{|c|c|c|c|c|c|}
\hline Scientific name & Family & Local name & Habit & Status & $\begin{array}{l}\text { Part } \\
\text { Used }\end{array}$ \\
\hline \multicolumn{6}{|l|}{ Mode of Utilization/Uses } \\
\hline \multicolumn{6}{|c|}{$\begin{array}{l}\text { A L infusion is taken for treatment of pneumonia. Charcoal is ground to powder or made into paste } \& \text { taken for } \\
\text { treatment of stomach ulcer. } A L \text { decoction is used for treatment of diabetes. }\end{array}$} \\
\hline Eupatorium adenophorum Spreng. & Asteraceae & Hlothar & Herb & LR & $\mathrm{L}$ \\
\hline \multicolumn{6}{|c|}{ Crushed $L$ juice is applied to stop nose bleeding. } \\
\hline Eupatorium cannabinum $\mathrm{L}$. & Asteraceae & Hlothar & Herb & LR & $\mathrm{L}$ \\
\hline \multicolumn{6}{|c|}{ Crushed $\mathrm{L}$ juice is applied to stop nose bleeding. } \\
\hline Euphorbia royleana Boiss. & Euphorbiaceae & Chawng & Shrub & LR & $\mathrm{Fr}, \mathrm{L}, \mathrm{Pi}$ \\
\hline \multicolumn{6}{|c|}{$\begin{array}{l}\mathrm{Pi} \& \text { unripe Fr of Carica papaya } \mathrm{L} \text {. is cooked with chicken \& the water is taken to treat diseases of the liver \& chronic } \\
\text { fever. Milky juice is used externally for ring worm, rheumatism, boils, warts. Juice of heated } L \text { are applied to earache. }\end{array}$} \\
\hline Ficus benghalensis L. & Moraceae & Hmawng & Tree & LR & $\begin{array}{l}\mathrm{B}, \mathrm{L}, \\
\mathrm{La}, \mathrm{R}, \mathrm{S}\end{array}$ \\
\hline \multicolumn{6}{|c|}{$\begin{array}{l}\text { The milky juice is applied externally for pains in rheumatism \& lumbago. A B infusion is used as a tonic, astringent, } \\
\& \text { for treatment of dysentery, diarrhoea \& diabetes. } S \text { is used as a cooling tonic. } L \text { are applied as a poultice to } \\
\text { abscesses. R fiber is used in treatment of gonorrhoea. }\end{array}$} \\
\hline Ficus prostrata (Wall. ex Miq.) Miq. & Moraceae & Theitit & Epiphytic & LR & $R$ \\
\hline \multicolumn{6}{|c|}{ Crushed $\mathrm{R}$ juice is applied for remedy of poisoned snake bites. } \\
\hline Ficus religiosa L. & Moraceae & Hmawnghnahzum & Tree & LR & $\mathrm{B}, \mathrm{L}$ \\
\hline \multicolumn{6}{|c|}{$\begin{array}{l}\text { B is used as an astringent, \& to treat gonorrhoea, dysentery, fever, scabies, \& piles. L \& young shoots are used as } \\
\text { purgatives \& to treat skin diseases. }\end{array}$} \\
\hline $\begin{array}{l}\text { Ficus semicordata Buch.-Ham. ex Sm. } \\
\text { var. conglomerata (Roxb.) Corner }\end{array}$ & Moraceae & Thenpui & Small tree & LR & $\mathrm{B}, \mathrm{L}$ \\
\hline \multicolumn{6}{|c|}{ B \& L together are used to treat liver ailments. } \\
\hline Flemingia macrophylla (Willd.) Prain & Fabaceae & Tuisithing Lalram* & Shrub & VU/NT & $\mathrm{R}$ \\
\hline \multicolumn{6}{|c|}{ A R decoction is used as an external application for treatment of swellings \& pain in the body. } \\
\hline Garcinia cowa Roxb. & Clusiaceae & Chengkek & Tree & LR & $\mathrm{B}, \mathrm{L}$ \\
\hline \multicolumn{6}{|c|}{ B \& L are for treatment of diarrhoea, leprosy \& ulcers. } \\
\hline Garcinia lanceifolia Roxb. & Clusiaceae & Pelhte & Tree & EN & $\mathrm{Fr}, \mathrm{L}$ \\
\hline \multicolumn{6}{|c|}{ Fr \& $L$ are used for remedy of stomach ache. } \\
\hline Garcinia paniculata Roxb. ex Wight & Clusiaceae & Vawmva & Tree & LR & S \\
\hline \multicolumn{6}{|l|}{ The $S$ are used in treatment of roundworms. } \\
\hline $\begin{array}{l}\text { Garcinia pedunculata Roxb. ex Buch.- } \\
\text { Ham. }\end{array}$ & Clusiaceae & Theipumlian & Tree & NT & $\mathrm{Fr}$ \\
\hline \multicolumn{6}{|c|}{ An acidic Fr pericarp extract solution is mixed with sugar \& is taken orally against dysentery $\&$ diarrhoea. } \\
\hline Gardenia coronaria Buch.-Ham. & Rubiaceae & Rul-hluah* Lalran & Tree & LR & $L, R$ \\
\hline \multicolumn{6}{|c|}{$50 \mathrm{ml}$ of an infusion of $R \& L$ is taken orally twice daily against snake bite. } \\
\hline Garcinia sopsopia Mabb. & Clusiaceae & Thensaker & Tree & NT & $\mathrm{Br}$ \\
\hline \multicolumn{6}{|l|}{$\mathrm{Br}$ is used to treat snake bite. } \\
\hline Garuga pinnata Roxb. & Burseraceae & Bangbutuairam & Tree & LR & $\mathrm{B}, \mathrm{L}$ \\
\hline \multicolumn{6}{|c|}{ Stem B juice is dropped into the eye to treat conjunctiva opacities. $L$ juice mixed with sugar is taken for asthma. } \\
\hline $\begin{array}{l}\text { Gelsemium elegans (Gardner \& } \\
\text { Champ.) Benth. }\end{array}$ & Gelsemiaceae & Hnamtur & Tree & EN/VU & $\mathrm{R}$ \\
\hline
\end{tabular}




\begin{tabular}{|l|l|l|l|l|l|l|}
\hline Scientific name & Family & Local name & Habit & Status & Part \\
Used
\end{tabular}

The Rh is used to remedy stomach ache, liver problems, vomiting, inflammation, pains, snake bite, \& as a carminative, tonic, stimulant, \& expectorant.

\begin{tabular}{|c|c|c|c|c|c|}
\hline Hedyotis scandens Roxb. & Rubiaceae & Laikingtuibur & Climber & LR & WP \\
\hline \multicolumn{6}{|c|}{ The WP is boiled \& the water is taken for treatment of swelling, malaria \& kidney problems. } \\
\hline Helianthus annuus L. & Asteraceae & Nihawipar & Herb & LR & S \\
\hline \multicolumn{6}{|c|}{$\begin{array}{l}\text { The } S \text { are used as diuretics, expectorants, febrifuges, \& in treatment of stomach ache, bronchitis, \& laryngeal or } \\
\text { pulmonary infections. }\end{array}$} \\
\hline Helicia excelsa Blume & Proteaceae & Sialhma & Tree & VU/NT & B \\
\hline \multicolumn{6}{|c|}{ A B decoction is used for remedy of stomach problems. } \\
\hline Helicia robusta $\mathrm{R}$. Br. ex Blume & Proteaceae & Sialhma & Tree & LR & B \\
\hline \multicolumn{6}{|c|}{$50 \mathrm{ml}$ of a B decoction is taken twice daily for remedy of stomach problems. } \\
\hline Hibiscus rosa-sinensis L. & Malvaceae & $\begin{array}{l}\text { Midumpangparl } \\
\text { Banglapar }\end{array}$ & Shrub & LR & $\mathrm{F}$ \\
\hline \multicolumn{6}{|c|}{ The raw $\mathrm{F}$ is taken for the remedy of jaundice. } \\
\hline Hodgsonia macrocarpa (Blume) Cogn. & Cucurbitaceae & Kha-um & Climber & LR & $\mathrm{L}$ \\
\hline
\end{tabular}

Crushed $L$ juice is applied on fresh cuts to stop bleeding \& treat wounds. Powdered $L$ are applied externally to treat ulcers.

\begin{tabular}{|c|c|c|c|c|c|}
\hline $\begin{array}{l}\text { Homalomena aromatica (Spreng.) } \\
\text { Schott }\end{array}$ & Araceae & Anchiri & Herb & LR & Rh,WP \\
\hline \multicolumn{6}{|c|}{ Rh is used as an aromatic stimulant. WP juice is used as a lotion for skin diseases. } \\
\hline Hoya griffithii Hook.f. & Apocynaceae & Hnahchhah & Herb & LR & L,Sa \\
\hline \multicolumn{6}{|c|}{ The $L$ sap is applied on the burned skin. } \\
\hline Hydnocarpus kurzii (King) Warb. & Flacourtiaceae & (King.) Warb. & Tree & CR/EN & $\mathrm{B}, \mathrm{Fr}$ \\
\hline
\end{tabular}

The smoke of burning $B$ is used for stupefying bees, especially honey-bees (Apis mellifica). Fr can be used for poisoning fish. The $S$ are sold by Lushai tribes for making an oil, frequently used as a remedy for leprosy.

\begin{tabular}{|l|l|l|l|l|l|}
\hline Hydrocotyle nepalensis Hook. & Apiaceae & $\begin{array}{l}\text { Hlovaidawrl } \\
\text { Darbengur }\end{array}$ & Herb & NT & L \\
\hline
\end{tabular}

$\mathrm{L}$ are used as diuretic, tonic, blood purifier, insecticidal, \& stimulant, \& for treatment of dysentery, stomach ache, scabies \& cutaneous diseases. 


\section{Rai \& Lalramnghinglova - Ethnomedicinal Plants of India with Special Reference to an Indo-Burma Hotspot Region: An overview}

\begin{tabular}{|c|c|c|c|c|c|}
\hline Scientific name & Family & Local name & Habit & Status & $\begin{array}{l}\text { Part } \\
\text { Used }\end{array}$ \\
\hline \multicolumn{6}{|l|}{ Mode of Utilization/Uses } \\
\hline Imperata cylindrica (L.) Raeusch. & Poaceae & Di & Grass & LR & $R$ \\
\hline \multicolumn{6}{|c|}{$\mathrm{R}$ juice is used for the removal or expelling of the intestinal worms. } \\
\hline $\begin{array}{l}\text { Inula cappa (Buch.-Ham. ex D. Don) } \\
\text { DC. }\end{array}$ & Asteraceae & Buarthau & Shrub & LR & L,WP \\
\hline \multicolumn{6}{|c|}{$\begin{array}{l}\text { The } L \text { are crushed with those of Plantago erosa Wall. ex Roxb. \& Lobelia angulata G. Forst. \& the juice is taken orally } \\
\text { three times daily for diabetes \& jaundice. }\end{array}$} \\
\hline Ixora nigricans R. Br. ex Wight \& Arn. & Rubiaceae & Thainurual & $\begin{array}{l}\text { Shrub/ } \\
\text { small tree }\end{array}$ & VU & $\mathrm{L}$ \\
\hline \multicolumn{6}{|c|}{ An infusion of the $L$ is prescribed for dysentery \& colic problems. } \\
\hline Jasminum nervosum Lour. & Oleaceae & Hrurkha & Shrub & LR & $\mathrm{L}$ \\
\hline \multicolumn{6}{|c|}{ The $L$ are used for the remedy of stomach ache \& fever. } \\
\hline Jatropha curcas L. & Euphorbiaceae & Kangdamdawi & Shrub & LR & $\mathrm{Br}, \mathrm{Fr}, \mathrm{L}$ \\
\hline \multicolumn{6}{|c|}{$\begin{array}{l}\text { Fr/nut is used as a purgative. } \mathrm{L} \text { are used as a remedy for scabies, eczema, \& ring worm. Br is used as tooth brush } \\
\text { for treating swollen gums. }\end{array}$} \\
\hline Juglans regia L. & Juglandaceae & Khawkherh & Tree & LR & $\mathrm{B}, \mathrm{Fr}, \mathrm{L}$ \\
\hline \multicolumn{6}{|c|}{$B \& L$ are used as antihelminthics. $L$ are used as astringents \& tonics. Fr is used as an antirheumatic. } \\
\hline Justicia adhatoda L. & Acanthaceae & Kawldai & Shrub & LR & $\mathrm{L}$ \\
\hline \multicolumn{6}{|c|}{$\begin{array}{l}\text { Crushed } L \text { juice is applied externally on cuts \& wounds to stop bleeding. The } L \text { are boiled \& } 20 \mathrm{ml} \text { of the water is taken } \\
\text { internally twice daily for } 3 \text { days as a treatment for malarial fever. } L \text { paste is applied on the whole body for } 24 \text { hours } \& \\
\text { the patient bathes on the third day to treat acute or chronic malaria. }\end{array}$} \\
\hline Kalanchoe pinnata (Lam.) Pers. & Crassulaceae & Zihor & Herb & NT/IN & $\mathrm{L}$ \\
\hline \multicolumn{6}{|c|}{ Scorched $L$ are applied on the forehead to treat vertigo. } \\
\hline Lagerstroemia speciosa (L.) Pers. & Lythraceae & Chawnpui/Thlado & Tree & LR & $B, R$ \\
\hline \multicolumn{6}{|c|}{ A R decoction is taken for jaundice. A B infusion is taken for diarrhoea \& dysentery. } \\
\hline $\begin{array}{l}\text { Laggera crispata (Vahl) Hepper \& } \\
\text { J.R.I. Wood }\end{array}$ & Asteraceae & Runhthung & Herb & LR & $\mathrm{L}$ \\
\hline \multicolumn{6}{|l|}{ Crushed $L$ are applied to treat sores. } \\
\hline Lannea corom\&elica (Houtt.) Merr. & Anacardiaceae & Tawitawsuak & Tree & LR & $\mathrm{B}, \mathrm{L}$ \\
\hline \multicolumn{6}{|c|}{ B is used as an astringent $\&$ for treatment of ulcers $\&$ sores. L are used for treatment of swellings, sprains $\&$ body pain. } \\
\hline Lantana camara L. & Verbenaceae & Hlingpangpar & Shrub & LR & $\mathrm{L}$ \\
\hline \multicolumn{6}{|c|}{ Leaves are used as a diaphoretic, antirheumatic, carminative $\&$ antispasmodic, $\&$ to treat malaria $\&$ tetanus. } \\
\hline Lasia spinosa (L.) Thwaites & Araceae & Zawngzang & Herb & NT & $\mathrm{Rh}$ \\
\hline \multicolumn{6}{|c|}{ Bawm medicine men prescribe a Rh infusion for throat-pain (diphtheria). } \\
\hline Lasianthus hirsutus (Roxb.) Merr. & Rubiaceae & Changneithing & $\begin{array}{l}\text { Large } \\
\text { shrub/ } \\
\text { small tree }\end{array}$ & LR & $L$ \\
\hline \multicolumn{6}{|l|}{$\mathrm{L}$ juice is applied to stop bleeding. } \\
\hline $\begin{array}{l}\text { Lasianthus wallichii (Wight \& Arn.) } \\
\text { Wight }\end{array}$ & Rubiaceae & Ruih-thing & Shrub & LR & $\mathrm{L}$ \\
\hline \multicolumn{6}{|c|}{ A decoction of $L$ is used as an hallucinogenic. } \\
\hline Leea compactiflora Kurz & Vitaceae & Kawlkar & Shrub & LR & $\mathrm{R}$ \\
\hline
\end{tabular}




\begin{tabular}{|c|c|c|c|c|c|}
\hline Scientific name & Family & Local name & Habit & Status & $\begin{array}{l}\text { Part } \\
\text { Used }\end{array}$ \\
\hline \multicolumn{6}{|l|}{ Mode of Utilization/Uses } \\
\hline $\begin{array}{l}\text { Lepidagathis incurva Buch.-Ham. ex } \\
\text { D. Don }\end{array}$ & Acanthaceae & Vangvattur & Herb & LR & $\mathrm{L}$ \\
\hline \multicolumn{6}{|l|}{$\mathrm{L}$ are used to stop bleeding. } \\
\hline Lepidagathis rigida Dalzell & Acanthaceae & Vangvattur & Herb & LR & $\mathrm{L}$ \\
\hline \multicolumn{6}{|l|}{$\mathrm{L}$ are used to treat tooth decay. } \\
\hline Lepionurus sylvestris Blume & Opiliaceae & Anpangthuam & Shrub & NT & $L$ \\
\hline \multicolumn{6}{|c|}{ A L decoction is taken as a treatment for diabetes. } \\
\hline Lindernia ruelloides (Colsm.) Pennell. & Scrophulariacea-e & Thasuih & Herb & EN/VU & WP \\
\hline \multicolumn{6}{|c|}{ WP is used externally for rheumatism, sciatica, skin worms, \& wounds. WP is used internally for eye problems. } \\
\hline Litchi chinensis Sonn. & Lauraceae & Theifeimung & Tree & NT & Fr,L \\
\hline \multicolumn{6}{|c|}{ Fr aril is used as a tonic. $L$ are used to treat animal bites. } \\
\hline Litsea cubeba (Lour.) Pers. & Lauraceae & Sernam & Tree & LR & $\mathrm{Fr}$ \\
\hline \multicolumn{6}{|c|}{$\begin{array}{l}\text { Fr is used as an antiparalytic, anticephalagic, antihysteric, \& carminative. Fr is used to treat dizziness \& loss of } \\
\text { memory. }\end{array}$} \\
\hline Litsea monopetala (Roxb.) Pers. & Lauraceae & Nauthak & Tree & LR & B \\
\hline \multicolumn{6}{|c|}{ B is used as an astringent, antidiarrheal, \& stimulant. B is used to treat stomach ache \& fractures. } \\
\hline Litsea cubeba (Lour.) Pers. & Lauraceae & Sernam & Tree & LR & $\mathrm{Fr}$ \\
\hline \multicolumn{6}{|c|}{ Fr is taken for hysteria, headache $\&$ paralysis. } \\
\hline Lobelia angulata G. Forst. & Campanulaceae & Choakthi & Shrub & & WP \\
\hline \multicolumn{6}{|c|}{$\begin{array}{l}\text { The WP is crushed with those of Plantago erosa Wall. ex Roxb. \& Inula cappa (Buch.-Ham. ex D. Don) DC. \& the juice } \\
\text { is taken orally three times daily for diabetes \& jaundice. }\end{array}$} \\
\hline Lobelia nicotianifolia Roth ex Schult. & Campanulaceae & Berawchal & Herb & EN/VU & WP \\
\hline \multicolumn{6}{|l|}{ WP juice is applied to boils \& irritated skin. } \\
\hline Lonicera macrantha (D. Don) Spreng. & Caprifoliaceae & Leihruisen & Climber & LR & $\mathrm{L}$ \\
\hline \multicolumn{6}{|l|}{$\mathrm{L}$ are used to treat diarrhoea. } \\
\hline Macaranga sp. & Euphorbiaceae & & Tree & LR & WP \\
\hline \multicolumn{6}{|c|}{ WP is boiled \& the water is taken to treat diabetes \& retained placenta. } \\
\hline Mallotus leucocarpus (Kurz) Airy Shaw & Euphorbiaceae & Sukiah & Small tree & LR & $\mathrm{R}$ \\
\hline \multicolumn{6}{|l|}{$\mathrm{R}$ are used to treat colic problems. } \\
\hline Mallotus philippensis (Lam.) Müll. Arg. & Euphorbiaceae & Bari khei & Tree & LR & $\mathrm{B}, \mathrm{St}$ \\
\hline \multicolumn{6}{|c|}{ Fr gland \& hair are used as antihelminthics \& styptics, \& used to treat scabies, ring worm \& herpes. } \\
\hline Mallotus roxburghianus Müll. Arg. & Euphorbiaceae & Zawngtenawhlung & Small tree & LR & $\mathrm{Br}$ \\
\hline \multicolumn{6}{|l|}{ Br used to treat jaundice \& hepatomegaly. } \\
\hline $\begin{array}{l}\text { Melocalamus compactiflorus (Kurz) } \\
\text { Benth. }\end{array}$ & Poaceae & Sairil & Climber & LR & St \\
\hline \multicolumn{6}{|l|}{ St juice is used to treat influenza. } \\
\hline Melastoma malabathricum L. & Melastomataceae & Builukham & $\begin{array}{l}\text { Evergreen } \\
\text { shrub }\end{array}$ & LR & $\mathrm{B}, \mathrm{F}, \mathrm{L}$ \\
\hline \multicolumn{6}{|c|}{$B$ is used as wound healer. $L$ is used as an antidiarrheal \& antiseptic. $L \& F$ used as an astringent $\&$ antileucorrhoeic. } \\
\hline Melia azedarach L. & Meliaceae & Nim-suak & Tree & NT/IN & $\mathrm{L}$ \\
\hline
\end{tabular}




\section{Rai \& Lalramnghinglova - Ethnomedicinal Plants of India with Special Reference to an Indo-Burma Hotspot Region: An overview}

\begin{tabular}{|c|c|c|c|c|c|}
\hline Scientific name & Family & Local name & Habit & Status & $\begin{array}{l}\text { Part } \\
\text { Used }\end{array}$ \\
\hline \multicolumn{6}{|l|}{ Mode of Utilization/Uses } \\
\hline \multicolumn{6}{|c|}{$\mathrm{A} L$ decoction is taken orally for treatment of fever \& hypertension. } \\
\hline Melocanna baccifera (Roxb.) Kurz & Poaceae & Mautak & Bamboo & LR & St \\
\hline \multicolumn{6}{|c|}{ The outer St epidermis is scraped off \& applied on cuts to stop bleeding. } \\
\hline Merremia umbellata (L.) Hallier f. & Convolvulaceae & Vawktesentil & Tree & LR & $\mathrm{L}$ \\
\hline \multicolumn{6}{|l|}{ A L poultice is applied on burns \& sores. } \\
\hline Mesua ferrea $\mathrm{L}$. & Calophyllaceae & Herhse & Tree & LR & $\mathrm{B}, \mathrm{F}, \mathrm{L}$ \\
\hline \multicolumn{6}{|c|}{$\mathrm{F}$ is used as an astringent $\&$ to treat stomach ache. $\mathrm{F} \& \mathrm{~L}$ are used to treat snakebite $\&$ scorpion stings. } \\
\hline Michelia champaca L. & Magnoliaceae & Ngiau & Tree & LR & $\mathrm{Fr}, \mathrm{L}, \mathrm{S}$ \\
\hline \multicolumn{6}{|c|}{ A L infusion with honey is used to treat colic. Crushed $\mathrm{Fr} \& \mathrm{~S}$ are made into a paste $\&$ applied to cracked skin on feet. } \\
\hline Mikania micrantha Kunth. & Asteraceae & Japan-hlo & Climber & LR & L \\
\hline \multicolumn{6}{|c|}{$\begin{array}{l}\text { L juice is used to stop bleeding \& treat dysentery. L boiled with B of Vitex peduncularis Wall. ex Schauer in A. DC. is } \\
\text { drunk to treat typhoid or malarial fever. }\end{array}$} \\
\hline Millettia pachycarpa Benth. & Fabaceae & Rulei & $\begin{array}{l}\text { Shrub/ } \\
\text { climber }\end{array}$ & LR & $\mathrm{R}$ \\
\hline \multicolumn{6}{|c|}{$\begin{array}{l}\text { A R infusion is used as a lotion to treat wounds, swellings, toothache, \& sprains. A R decoction is used for washing } \\
\text { scabies \& itches. }\end{array}$} \\
\hline Millettia piscidia Wight \& Arn. & Fabaceae & Ruteng & Tree & NT/E & $\mathrm{Fr}, \mathrm{R}$ \\
\hline \multicolumn{6}{|c|}{$\mathrm{R}$ are used to treat infertility. A Fr(S) decoction is used as an abortifacient. } \\
\hline Mimosa invisa Mart. ex Colla & Fabaceae & Dihlo & Climber & LR & $\mathrm{R}$ \\
\hline \multicolumn{6}{|c|}{ A R infusion is used to treat kidney/gall bladder stones. } \\
\hline Mimosa pudica L. & Fabaceae & Hlonuar & Herb & LR & L,R \\
\hline \multicolumn{6}{|c|}{$\mathrm{L} \& \mathrm{R}$ are used to remove piles \& pistula. A R decoction is used to treat gall-bladder/kidney problems. } \\
\hline Mirabilis jalapa L. & Nyctaginaceae & Ar-atukkhuan & Shrub & LR & $L, R$ \\
\hline \multicolumn{6}{|c|}{$\begin{array}{l}\mathrm{R} \text { are used as a purgative } \& \text { aphrodisiac, } \& \text { in treatment of dropsy } \& \text { piles. } L \text { are used as a tonic } \& \text { for treatment of } \\
\text { inflammatory, boils, \& whitlow. }\end{array}$} \\
\hline Morinda angustifolia Roxb. & Rubiaceae & Kawrpel & Shrub & LR & $\mathrm{L}$ \\
\hline \multicolumn{6}{|c|}{ A L poultice is applied to cracked skin on feet. } \\
\hline Morus australis Poir. & Moraceae & Lungli & Tree & VU & $\mathrm{B}, \mathrm{L}, \mathrm{R}$ \\
\hline \multicolumn{6}{|c|}{$B$ is as a purgative. $A L$ decoction is used as a gargle for inflammation of the vocal cords. $R$ are used as an astringent. } \\
\hline Mucuna pruriens (L.) DC. & Fabaceae & Uiteme & Climber & LR & $\mathrm{Fr}, \mathrm{R}$ \\
\hline \multicolumn{6}{|c|}{$\begin{array}{l}\mathrm{R} \text { are used as a diuretic } \& \text { purgative, } \& \text { to treat dropsy, fevers } \& \text { kidney problems. } S \text { are used as aphrodisiacs } \& \text { nerve } \\
\text { tonics. Fr bristles are used as a vermifuge, \& for treatment of liver } \& \text { gall bladder diseases, parkinsonism \& ulcers. }\end{array}$} \\
\hline Murraya koenigii (L.) Spreng. & Rutaceae & Arpatil & Herb & LR & WP \\
\hline \multicolumn{6}{|c|}{$\begin{array}{l}\text { WP is used as a tonic } \& \text { to treat stomach ache } \& \text { diabetes. } L \text { are used as a febrifuge, } \& \text { to treat dysentery, \& kidney } \\
\text { pain. L, B \& R are used as stimulants, carminatives \& to treat diabetes. }\end{array}$} \\
\hline $\begin{array}{l}\text { Myrica esculenta Buch.-Ham. ex } \\
\text { D. Don }\end{array}$ & Myricaceae & Keifang & Herb & LR & $\mathrm{B}, \mathrm{Fr}$ \\
\hline \multicolumn{6}{|c|}{$\begin{array}{l}\text { B is used as a rubifacient, antiseptic, carminative, antiasthmatic, \& diuretic, } \& \text { is used to treat bronchitis. Fr used as } \\
\text { a sedative \& to treat stomach ache. }\end{array}$} \\
\hline Musa acuminata $\mathrm{X}$ balbisiana Colla & Musaceae & Balhla & Herb & LR & Sa \\
\hline \multicolumn{6}{|l|}{ The sap of stem is applied for antiseptic } \\
\hline Musa sp. & Musaceae & Changel & Herb & LR & Sa \\
\hline
\end{tabular}




\begin{tabular}{|c|c|c|c|c|c|}
\hline Scientific name & Family & Local name & Habit & Status & \begin{tabular}{|l} 
Part \\
Used
\end{tabular} \\
\hline \multicolumn{6}{|l|}{ Mode of Utilization/Uses } \\
\hline \multicolumn{6}{|c|}{ St Sa in combination with the chicken blood is given to treat epilepsy. Sa is used to treat snake bites. } \\
\hline Ensete glaucum (Roxb.) Cheesman & Musaceae & Saisu & Herb & NT & S \\
\hline \multicolumn{6}{|c|}{$\mathrm{S}$ are made into beads $\&$ put on children to prevent convulsions. } \\
\hline Neolamarckia cadamba (Roxb.) Bosser & Rubiaceae & Banphar & Tree & LR & L,Sa \\
\hline \multicolumn{6}{|c|}{ Sa that oozes out of cut branchlets is used as lotion for bone ache \& swellings. } \\
\hline Ocimum gratissimum $\mathrm{L}$. & Lamiaceae & Khum-bang-bang & Shrub & NT/C & $F, L$ \\
\hline
\end{tabular}

A strong $L \& F$ decoction is given to children for aphthae. A $L$ decoction is used as an aphrodisiac \& to treat gonorrhoea.

\begin{tabular}{|l|l|l|l|l|l}
\hline Ocimum tenuiflorum L. & Lamiaceae & Runhmui-dum & Shrub & NT/C & WP \\
\hline
\end{tabular}

The steam of boiling WP is inhaled to treat hepatitis. A WP infusion is used to treat cough, bronchitis, gastric disorders $\&$ as a mosquito repellent.

\begin{tabular}{|l|l|l|l|l|l}
\hline Oroxylum indicum (L.) Kurz & Bignoniaceae & Archangkawn & Small tree & LR & $B, R, S$ \\
\hline
\end{tabular}

$\mathrm{R} \& \mathrm{~B}$ are used as a tonic \& antidiarrheal. $\mathrm{B}$ is used to treat rheumatism. Tender Fr is used as a carminative \& for stomach ache. $S$ are used as a purgative. St is used as an treatment for scorpion stings.

\begin{tabular}{l|l|l|l|l|l}
\hline Osbeckia sikkimensis Craib & Melastomataceae & Builukhampa & Shrub & LR & R
\end{tabular}

Steamed $R$ \& extracted solution is taken internally for renal disorder \& genital-urinary problems. A R decoction is taken to treat kidney problem \& stomach ache.

\begin{tabular}{|l|l|l|l|l|l|}
\hline Paederia foetida L. & Rubiaceae & Vawihuihhrui & Climber & LR & L,R \\
\hline
\end{tabular}

$R \& L$ are used as a tonic. $R$ are used to remove piles, \& to treat pain in the chest \& liver. $L$ are used as a carminative, astringent, \& diuretic.

\begin{tabular}{|l|l|l|l|l|l|}
\hline Pajanelia longifolia K. Schum. & Bignoniaceae & $\begin{array}{l}\text { Ram- } \\
\text { archangkawm }\end{array}$ & Tree & NT & L,St \\
\hline L \& St paste is used to treat fractures \\
\hline Parabarium hookeri Pierre ex Spire & Apocynaceae & Theikelkibawr & Climber & LR & R \\
\hline A R decoction is taken as a tea to prevent placental disorders. & Zawngtah & Tree & LR & B,Br,Fr \\
\hline Parkia timoriana (DC.) Merr. & Fabaceae & Lree
\end{tabular}

A B \& twig decoction is taken orally to treat diarrhoea \& dysentery. Green Fr exocarps (pods) are ground into a paste \& applied on cuts \& wounds. Chakmas use a hot infusion of scraped pods to treat diarrhoea \& dysentery.

\begin{tabular}{|l|l|l|l|l|l|}
\hline Pavetta indica L. & Rubiaceae & Pavet-var & Hairy shrub & LR & Fr, L, R \\
\hline
\end{tabular}

$R$ are used to treat dropsy, jaundice $\&$ headaches, $\&$ are used as a diuretic $\&$ tonic. $R \& L$ are used to treat boils. $L$ are used to treat hemorrhoids. Fr is used as an antihelminthic.

\begin{tabular}{|l|l|l|l|l|l|l|}
\hline Passiflora nepalensis Walp. & Passifloraceae & Nauawimu & Climber & LR & R \\
\hline R are boiled \& the water is taken to treat malaria. & Malvaceae & Parsenbial & Herb & EN/VU & L \\
\hline Pentapetes phoenicea L. & L & Shrub & EN/VU & L \\
\hline L are boiled \& the water is taken to treat inflamed glands, cough \& colds. L juice is applied on inflamed glands. \\
\hline $\begin{array}{l}\text { Phyllanthus airy-shawii Brunel \& J.P. } \\
\text { Roux }\end{array}$ & Phyllanthaceae & Mawsai & & \\
\hline
\end{tabular}

L juice is applied externally on measles, skin eruptions \& inflamed glands. A L infusion is taken orally for diphtheria.

\begin{tabular}{|l|l|l|l|l|l}
\hline Phyllanthus emblica L. & Phyllanthaceae & Sunhlu & Tree & LR & WP \\
\hline
\end{tabular}

$B$ juice is used to treat diarrhoea \& dysentery. $A L$ decoction is used as a gargle for stomatitis \& bleeding gums. A $S$ decoction is used as an eye wash. Fr juice is taken to treat liver cirrhosis.

\begin{tabular}{|l|l|l|l|l|l|}
\hline Phyllanthus fraternus G.L. Webster & Phyllanthaceae & Mitthi sunhlu & Herb & EN/VU & Fr,WP \\
\hline
\end{tabular}




\section{Rai \& Lalramnghinglova - Ethnomedicinal Plants of India with Special Reference to an Indo-Burma Hotspot Region: An overview}

\begin{tabular}{|c|c|c|c|c|c|}
\hline Scientific name & Family & Local name & Habit & Status & $\begin{array}{l}\text { Part } \\
\text { Used }\end{array}$ \\
\hline \multicolumn{6}{|l|}{ Mode of Utilization/Uses } \\
\hline \multicolumn{6}{|c|}{$\begin{array}{l}50 \mathrm{ml} \text { of WP infusion is taken twice daily to treat diabetes. WP juice is used to treat liver problems \& jaundice. Fr is } \\
\text { used to treat bronchitis, leprosy, anaemia, urinary discharges, anuria \& asthma. }\end{array}$} \\
\hline $\begin{array}{l}\text { Phlogacanthus thyrsiformis (Roxb. ex } \\
\text { Hardw.) Mabb. }\end{array}$ & Acanthaceae & Khumtiangkohha & Shrub & LR & $\mathrm{R}$ \\
\hline \multicolumn{6}{|c|}{$\mathrm{R}$ are used to treat ulcers in combination with other plants. } \\
\hline Picrasma javanica Blume & Simaroubaceae & Thing damdawi & Tree & LR & B \\
\hline \multicolumn{6}{|c|}{$\begin{array}{l}25 \mathrm{ml} \text { of a } \mathrm{R} \text { decoction is taken internally twice daily for fever \& malaria. } 50 \mathrm{ml} \text { of a B decoction is taken } 2-3 \text { times } \\
\text { daily to treat diabetes \& hypertension. }\end{array}$} \\
\hline Piper betle L. & Piperaceae & Pandawng & Climber & LR & $L, R$ \\
\hline \multicolumn{6}{|c|}{$\begin{array}{l}L \text { are used as a carminative } \& \text { stimulant, } \& \text { for treatment of stomach ache, snake bite, eye pain, \& night blindness. Oil } \\
\text { is used to treat spasms \& infections such as diphtheria. } R \text { are used as a female contraceptive. }\end{array}$} \\
\hline Piper diffusum Vahl. & Piperaceae & Pawhrual & Climber & LR & L \\
\hline \multicolumn{6}{|l|}{$L$ are used to treat stomach ache. } \\
\hline Pithecellobium monadelphum Kosterm. & Fabaceae & Ardahte & Tree & LR & $L, S$ \\
\hline \multicolumn{6}{|c|}{$L$ are used to treat leprosy $\&$ to promote hair growth. $S$ are used to treat diabetes. } \\
\hline Plantago erosa Wall. ex Roxb. & Plantaginaceae & Kelba-an & Herb & LR & L,WP \\
\hline \multicolumn{6}{|c|}{$\begin{array}{l}\text { The L \& WP are crushed with those of Lobelia angulata G. Forst. \& Inula cappa (Buch.-Ham. ex D. Don) DC. \& the } \\
\text { juice is taken orally three times daily for diabetes \& jaundice. }\end{array}$} \\
\hline Plumeria acuminata W.T. Aiton & Apocynaceae & Vaingai & Tree & LR & B,La,R \\
\hline \multicolumn{6}{|c|}{$\begin{array}{l}\mathrm{R} \& \mathrm{~B} \text { are used to treat gonorrhoea } \& \text { herpes. } \mathrm{B} \text { is used as an emmenagogue } \& \text { to treat dropsy } \& \text { diarrhoea. La is } \\
\text { used as a rubefacient } \& \text { to treat rheumatism \& gum problems. }\end{array}$} \\
\hline Podocarpus neriifolius D. Don & Podocarpaceae & Thlang-far & Tree & VU & $\mathrm{L}$ \\
\hline \multicolumn{6}{|c|}{$L$ are boiled in water that is then used for bathing. A B decoction is applied with cotton on herpes. } \\
\hline Polygonum barbatum L. & Polygonaceae & Anbawng & Herb & LR & $\mathrm{S}$ \\
\hline \multicolumn{6}{|l|}{$S$ are taken to treat colic $\&$ infections. } \\
\hline Polygonum chinense L. & Polygonaceae & Taham & Herb & $\mathrm{DD}$ & $L, R$ \\
\hline \multicolumn{6}{|c|}{$\begin{array}{l}\mathrm{R} \text { are used as an astringent. } \mathrm{L} \text { are used to treat fly-infected wounds on goats. } S \text { are used as a tonic, purgative, } \& \\
\text { emetic. }\end{array}$} \\
\hline Pothos cathcartii Schott & Araceae & Lehpong & Epiphyte & LR & St \\
\hline \multicolumn{6}{|l|}{ St are used in to treat bone fractures. } \\
\hline Pothos scandens L. & Araceae & Leh-pong & Climber & LR & L,St \\
\hline \multicolumn{6}{|l|}{$L \& S t$ are used to treat bone fractures. } \\
\hline Pottsia laxiflora (Blume) Kuntze & Apocynaceae & Ludi-rani-tak & Climber & LR & $L, R$ \\
\hline \multicolumn{6}{|c|}{$\mathrm{R} \& \mathrm{~L}$ infusions are taken to treat snake bites. } \\
\hline Pratia begonifolia (Wall.) Lindl. & Campanulaceae & Choak-thi & Herb & LR & $\mathrm{L}$ \\
\hline \multicolumn{6}{|c|}{ Crushed $L$ juice is taken to treat dysentery \& vomiting. } \\
\hline $\begin{array}{l}\text { Pseudodrynaria coronans (Wall. } \\
\text { ex Mett.) Ching }\end{array}$ & Polypodiaceae & Awmvel & Epiphyte & LR & $\mathrm{Rh}$ \\
\hline \multicolumn{6}{|c|}{ Rh are used to treat stomach $\&$ tooth problems. } \\
\hline Pteridium aquilinum (L.) Kuhn & Dennstaetiaceae & Katchat & Herb & LR & $\mathrm{Rh}$ \\
\hline
\end{tabular}




\begin{tabular}{|l|l|l|l|l|l|l|}
\hline Scientific name & Family & Local name & Habit & Status & $\begin{array}{l}\text { Part } \\
\text { Used }\end{array}$ \\
\hline Mode of Utilization/Uses & Malvaceae & $\begin{array}{l}\text { Siksil (Kanak } \\
\text { champa) }\end{array}$ & Exotic tree & LR & $B, F, L$ \\
\hline Pterospermum acerifolium Willd.
\end{tabular}

B is used to treat headaches. F are used as a tonic \& to treat inflammation, stomach ache, tumors, leprosy, \& ulcers. $L$ hairs are used to stop bleeding.

\begin{tabular}{|l|l|l|l|l|l}
\hline Quercus leucotrichophora A. Camus & Fagaceae & Then/Phen & Tree & LR & R
\end{tabular}

$\mathrm{R}$ is used as a diuretic \& astringent, \& to treat gonorrhea, diarrhoea, \& asthma.

\begin{tabular}{|l|l|l|l|l|l|}
\hline $\begin{array}{l}\text { Rauvolfia serpentina (L.) Benth. } \\
\text { ex Kurz }\end{array}$ & Apocynaceae & Rullturzung & Herb & $\begin{array}{l}\text { EN, } \\
\text { VU. C }\end{array}$ & R \\
\hline
\end{tabular}

$\mathrm{R}$ are used to treat hypertension $\&$ stomach problems.

\begin{tabular}{|l|l|l|l|l|l|}
\hline Rhus acuminata DC. & Anacardiaceae & Chhimhruk & Herb & LR & Fr, L
\end{tabular}

$L$ are used to treat nausea. Fr are used to treat colic. $L$ are used to treat excrescences \& diarrhoea.

\begin{tabular}{|l|l|l|l|l|l|}
\hline $\begin{array}{l}\text { Rhaphidophora decursiva (Roxb.) } \\
\text { Schott }\end{array}$ & Araceae & Makhal & Epiphyte & LR & L,St \\
\hline
\end{tabular}

Crushed L \& St paste is used to treat bone fractures.

\begin{tabular}{|l|l|l|l|l|l|}
\hline Rhaphidophora hookeri Schott. & Araceae & Thiallawn & Climber & NT & L,St
\end{tabular}

$\mathrm{L} \& \mathrm{St}$ are used to ease the process of labor. $\mathrm{L}$ are used to treat malaria.

\begin{tabular}{|l|l|l|l|l|l|}
\hline Ricinus communis L. & Euphorbiaceae & Mutih & $\begin{array}{l}\text { Shrub or } \\
\text { small tree }\end{array}$ & NT & L,St \\
\hline
\end{tabular}

Heated young $L$ are used to treat ulcers, sciatica \& paralysis. Crushed $L$ are applied as bandage to treat urinary problems.

\begin{tabular}{|l|l|l|l|l|l|}
\hline Rubia cordifolia L. & Rubiaceae & Rawngsen & $\begin{array}{l}\text { Climber/ } \\
\text { creeping } \\
\text { herb }\end{array}$ & EN/VU & Root \\
\hline
\end{tabular}

Boiled $R$ are taken orally for kidney problem \& liver ailments. $R$ are used to treat gonorrhoea, syphilis \& renal infections.

\begin{tabular}{|l|l|l|l|l|l|l|}
\hline Ruellia suffruticosus Roxb. & Acanthaceae & Savangama & Herb & CR/VU & WP \\
\hline WP are used to treat renal infection, gonorrhoea, syphilis \& other venereal diseases. & \multicolumn{4}{|l|}{} \\
\hline Salix tetrasperma Roxb. & Salicaceae & Tuipuisuthlah & Tree & LR & B \\
\hline B is used as a febrifuge. & Sapindaceae & Hlingsi & Tree & LR & Fr,S \\
\hline Sapindus mukorossi Gaertn. & S
\end{tabular}

Fr is used as an emetic, expectorant $\&$ when there is excess salivation. Fr is used to treat epilepsy $\&$ chlorosis. $S$ are used to treat fevers \& dental caries.

\begin{tabular}{|l|l|l|l|l|l|}
\hline Saraca asoca (Roxb.) De Wilde & Fabaceae & Mualhawih & Tree & EN/VU & B
\end{tabular}

$\mathrm{B}$ is used for uterine inflation, as an astringent, \& in treatment of gonorrhoea \& scorpion stings.

\begin{tabular}{|l|l|l|l|l|l|}
\hline Schima wallichii (DC.) Korth. & Theaceae & Khiang & Tree & LR & B,Fr,L \\
\hline
\end{tabular}

A Fr decoction is used for snake \& insect bites. B is used as a rubefacient, antihelminthic, \& to treat gonorrhoea. L are used as a carminative.

\begin{tabular}{|l|l|l|l|l|l|}
\hline Scoparia dulcis L. & Plantaginaceae & $\begin{array}{l}\text { Perhpawng- } \\
\text { chaw/Hlothlum }\end{array}$ & Herb & LR & WP \\
\hline
\end{tabular}

Crushed WP juice is taken to treat kidney stones, jaundice \& genital-urinary problems.

\begin{tabular}{|l|l|l|l|l|l|}
\hline $\begin{array}{l}\text { Securinega virosa (Roxb. ex Willd.) } \\
\text { Baill. }\end{array}$ & Euphorbiaceae & Saisiak & Shrub & LR & L \\
\hline L boiled in water are used to bathe children suffering from scabies \& measles. \\
\hline Semecarpus anacardium L.f. & Anacardiaceae & Vawmbal-pui & Tree & LR & Fr \\
\hline
\end{tabular}




\section{Rai \& Lalramnghinglova - Ethnomedicinal Plants of India with Special Reference to an Indo-Burma Hotspot Region: An overview}

\begin{tabular}{|c|c|c|c|c|c|}
\hline Scientific name & Family & Local name & Habit & Status & $\begin{array}{l}\text { Part } \\
\text { Used }\end{array}$ \\
\hline \multicolumn{6}{|l|}{ Mode of Utilization/Uses } \\
\hline \multicolumn{6}{|c|}{$\mathrm{Fr}(\mathrm{nut})$ juice is applied externally to treat sprains \& rheumatism. } \\
\hline $\begin{array}{l}\text { Senecio sc\&ens Buch.-Ham. ex } \\
\text { D. Don }\end{array}$ & Asteraceae & Sai-ek-hlo & Climber & $\mathrm{CR}$ & $A, L$ \\
\hline \multicolumn{6}{|c|}{ Boiled A \& $L$ are used to treat cancer \& ulcers. } \\
\hline Sida acuta Burm.f. & Malvaceae & Khingkhih & Shrub & LR & $\mathrm{R}$ \\
\hline \multicolumn{6}{|c|}{ Crushed $\mathrm{R}$ are applied on boils to draw out pus. $\mathrm{R}$ are used to treat nervous, urinary, stomach, $\&$ gastric diseases. } \\
\hline Smilax glabra Roxb. & Smilacaceae & Tluang-ngil & Climber & LR & $\mathrm{R}$ \\
\hline \multicolumn{6}{|c|}{$\mathrm{R}$ are used to treat uterine \& stomach infections. } \\
\hline Smilax parvifolia Wall. ex Hook. f. & Smilacaceae & Kaiha & Climber & LR & $\mathrm{R}$ \\
\hline \multicolumn{6}{|c|}{ Ground $\mathrm{R}$ with old molasses or coagulated cows milk is mixed with water $\&$ taken orally as a blood purifier. } \\
\hline $\begin{array}{l}\text { Solanum khasianum C.B. Clarke var. } \\
\text { chatterjeeanum Sengupta }\end{array}$ & Solanaceae & Athlo & Shrub & VU & $\mathrm{Fr}, \mathrm{S}$ \\
\hline \multicolumn{6}{|c|}{ Fr \& S are used to treat dental problems ("expel tooth worms from the mouth"). } \\
\hline Solanum nigrum $\mathrm{L}$. & Solanaceae & Anhling & Herb & LR & WP \\
\hline \multicolumn{6}{|c|}{ A WP infusion is used to treat liver problems \& dropsy. } \\
\hline Solanum torvum Sw. & Solanaceae & Tawkpui & Shrub & LR & $\mathrm{S}$ \\
\hline \multicolumn{6}{|c|}{ Crushed S are applied to treat a toothache \& tooth decay. } \\
\hline Sonchus wightianus DC. & Asteraceae & Gangmula & Herb & LR & $\mathrm{R}$ \\
\hline \multicolumn{6}{|l|}{ R are used as a cardiac tonic. } \\
\hline Spondias pinnata (L.f.) Kurz & Anacardiaceae & Tawitaw & Tree & LR & $\mathrm{B}$ \\
\hline \multicolumn{6}{|c|}{ B is used as a refrigerant $\&$ to treat dysentery. B mixed with water is used to treat auricular $\&$ muscular rheumatism. } \\
\hline Stemona tuberosa Lour. & Stemonaceae & Kaimam & Climber & EN & $\mathrm{R}$ \\
\hline \multicolumn{6}{|c|}{$10 \mathrm{ml}$ of a $\mathrm{R}$ infusion is taken internally twice daily for tuberculosis \& fever. } \\
\hline $\begin{array}{l}\text { Stephania japonica (Thunb.) Miers var. } \\
\text { discolor (Blume) Forman }\end{array}$ & Menispermaceae & Hruifei & Climber & VU & $\mathrm{R}$ \\
\hline \multicolumn{6}{|c|}{ A R infusion is taken orally to treat diarrhoea, fever \& dyspepsia. } \\
\hline Sterculia urens Roxb. & Malvaceae & Pangkhau & Tree & LR & G,L,R \\
\hline \multicolumn{6}{|c|}{$\begin{array}{l}\mathrm{G} \text { is used to treat throat infections. } \mathrm{L} \& \text { tender branches are used to treat pleuropneumonia in cattle, \& to treat } \\
\text { dysentery \& piles. }\end{array}$} \\
\hline $\begin{array}{l}\text { Stereospermum colais (Buch.-Ham. ex } \\
\text { Dillwyn) Mabb. }\end{array}$ & Bignoniaceae & Zihngal & Tree & LR & $\mathrm{L}$ \\
\hline \multicolumn{6}{|c|}{$A L$ decoction is used as a febrifuge. $L$ juice is applied to relieve itching. } \\
\hline Stereospermum neuranthum Kurz & Bignoniaceae & Zihaw & Tree & LR & W \\
\hline \multicolumn{6}{|l|}{ W is used to treat chronic ulcers. } \\
\hline Styrax serrulata F.B. Forbes \& Hemsl. & Styracaceae & Hmarhleng & Shrub & LR & Resin \\
\hline \multicolumn{6}{|c|}{ Resin is used as an antiseptic, stimulant \& expectorant. } \\
\hline $\begin{array}{l}\text { Swertia angustifolia Buch.-Ham. ex } \\
\text { D. Don }\end{array}$ & Gentianaceae & Khawsik damdawl & Herb & LR & $\begin{array}{l}\text { WPI } \\
\text { stem B }\end{array}$ \\
\hline \multicolumn{6}{|c|}{ A WP infusion is used to treat malarial fever. } \\
\hline Syzygium cerasoides (Roxb.) Raizada & Myrtaceae & Lenhmui & Tree & LR & Fr,L,R \\
\hline
\end{tabular}




\begin{tabular}{|c|c|c|c|c|c|}
\hline Scientific name & Family & Local name & Habit & Status & $\begin{array}{l}\text { Part } \\
\text { Used }\end{array}$ \\
\hline \multicolumn{6}{|l|}{ Mode of Utilization/Uses } \\
\hline \multicolumn{6}{|c|}{ Fr is used to treat rheumatism. $L$ are used as compresses. $R$ are used as a rubefacient. } \\
\hline Syzygium cumini (L.) Skeels & Myrtaceae & Lenhmui & Tree & LR & $\mathrm{B}, \mathrm{Fr}, \mathrm{L}$ \\
\hline \multicolumn{6}{|c|}{$\begin{array}{l}B \text { is used as an astringent. Fr is used to treat stomach ache \& is used as a carminative \& diuretic. B \& } S \text { are used to } \\
\text { treat diabetes. B \& L are used to treat diarrhoea. }\end{array}$} \\
\hline $\begin{array}{l}\text { Tabernaemontana divaricata (L.) R. Br. } \\
\text { ex Roem. \& Schult. }\end{array}$ & Apocynaceae & Pararsi & Shrub & LR & $\mathrm{R}, \mathrm{Sa}$ \\
\hline \multicolumn{6}{|c|}{$\begin{array}{l}\mathrm{R} \text { are chewed for the relief of tooth-ache \& gum boils. R paste is applied 1-2 times daily on mouth ulcers. Sa mixed } \\
\text { with oil is rubbed on the forehead to treat pain in the eyes \& head. }\end{array}$} \\
\hline Taraktogenos kurzii King & Achariaceae & Khawitur & Tree & NT & S \\
\hline \multicolumn{6}{|c|}{ S oil is applied for treatment of leprosy \& skin diseases. } \\
\hline Tarenna odorata (Roxb.) B.L. Rob. & Rubiaceae & Khalagor song & Shrub & LR & $\mathrm{R}$ \\
\hline \multicolumn{6}{|l|}{$\mathrm{R}$ paste is applied on snake bites. } \\
\hline Terminalia bellirica (Gaertn.) Roxb. & Combretaceae & Thingv\&awt & Tree & LR & $\mathrm{B}, \mathrm{Fr}$ \\
\hline \multicolumn{6}{|c|}{$\begin{array}{l}\text { Fr is taken for treatment of stomach problems, piles, sore throat } \& \text { diseases of the eye } \& \text { nose. Fr is used to treat } \\
\text { dropsy, leprosy, inflammation, diarrhea, asthma, headaches, \& is a taken as a tonic for bronchitis. Fr (kernel) is used } \\
\text { as a narcotic \& aphrodisiac. B is used as a diuretic \& to treat anaemia \& leucoderma. }\end{array}$} \\
\hline Terminalia chebula Retz. & Combretaceae & Reraw & Tree & VU & $\mathrm{B}, \mathrm{Fr}$ \\
\hline \multicolumn{6}{|c|}{$\begin{array}{l}\text { Fr is used to treat stomach problems, fevers, asthma, dysentery, piles, colds, sore throats, dental caries, bleeding } \& \\
\text { ulcerated gums, opthamia, \& is used as a purgative \& antiparalytic. Fr is also thought to enrich the blood. B is used } \\
\text { as a diuretic \& cardiotonic. }\end{array}$} \\
\hline Tetracera sarmentosa (L.) Vahl & Dilleniaceae & Hruithingdeng & Tree & LR & $\mathrm{B}$ \\
\hline \multicolumn{6}{|c|}{$\mathrm{AB}$ decoction is taken orally to treat stomach ache. } \\
\hline Tetrameles nudiflora R.Br. & Tetramelaceae & Thingdawl & Tree & LR & $\mathrm{B}, \mathrm{L}$ \\
\hline \multicolumn{6}{|c|}{ B \& L juice is dropped into ear to treat ear infection. } \\
\hline Thunbergia gr\&iflora Roxb. & Acanthaceae & Zawngafian & Climber & NT & $\mathrm{L}$ \\
\hline \multicolumn{6}{|c|}{$\mathrm{L}$ juice is used to treat diabetes, eye diseases $\&$ as an antiseptic for treatment of cuts $\&$ wounds. } \\
\hline Tinospora cordifolia (Willd.) Miers & Menispermaceae & Theisawntlung & $\begin{array}{l}\text { Shrub/ } \\
\text { climber }\end{array}$ & CR/VU & $\mathrm{Fr}, \mathrm{R}, \mathrm{St}$ \\
\hline \multicolumn{6}{|c|}{$\begin{array}{l}\text { St are used to treat skin diseases, stomach ache, spasms, inflammation, diabetes, diuretic, piles, anemia, \& as an } \\
\text { emetic, aphrodisiac, \& antiperiodic. R are used as an emetic and to treat leprosy. Fr is used as a tonic \& to treat } \\
\text { rheumatism. St \& Fr are used to treat jaundice. }\end{array}$} \\
\hline Toona ciliata M. Roem. & Meliaceae & Teipui & Tree & LR & $B \& F$ \\
\hline \multicolumn{6}{|c|}{ B is used as an astringent $\&$ tonic, $\&$ to treat dysentery $\&$ ulcers. $F$ are used as an emmenagogue. } \\
\hline $\begin{array}{l}\text { Trapa natans L. var. bispinosa (Roxb.) } \\
\text { Makino }\end{array}$ & Trapaceae & Singhara & \begin{tabular}{|l} 
Macro- \\
phyte
\end{tabular} & CR/VU & $\mathrm{Fr}$ \\
\hline \multicolumn{6}{|c|}{ Fr is used as a nutritious food. An infusion of aerial parts is used to treat diarrhoea. } \\
\hline Trema orientalis (L.) Blume & Cannabaceae & Belphuar & Tree & I/LR & $B, L, R$ \\
\hline \multicolumn{6}{|c|}{$B, L \& R$ are used to treat epilepsy. $R$ are used to treat diarrhoea. B is used to treat muscular pain. } \\
\hline Trevesia palmata (Roxb. ex Lindl.) Vis. & Araliaceae & Kawhtebel & Small tree & LR & L,R \\
\hline \multicolumn{6}{|c|}{ Crushed L juice is taken to treat colic, stomach ache \& high blood pressure. } \\
\hline Uncaria sessilifructus Roxb. & Rubiaceae & $\begin{array}{l}\text { Ralsamkuai- } \\
\text { ziksen }\end{array}$ & Climber & LR & $L \& R$ \\
\hline
\end{tabular}




\section{Rai \& Lalramnghinglova - Ethnomedicinal Plants of India with Special Reference to an Indo-Burma Hotspot Region: An overview}

\begin{tabular}{|c|c|c|c|c|c|}
\hline Scientific name & Family & Local name & Habit & Status & $\begin{array}{l}\text { Part } \\
\text { Used }\end{array}$ \\
\hline \multicolumn{6}{|l|}{ Mode of Utilization/Uses } \\
\hline Urena lobata L. & Malvaceae & Sehnap & Shrub & LR & $L, R$ \\
\hline \multicolumn{6}{|c|}{ Crushed $\mathrm{R}$ mixed with water is taken as an aphrodisiac. $\mathrm{L}$ juice is used to treat rheumatism. } \\
\hline Vernonia albicans DC. & Asteraceae & Dawn-do-u-pun & Herb & LR & $\mathrm{L}$ \\
\hline \multicolumn{6}{|c|}{ A warmed $L$ infusion is dropped into ear to treat earache or ear infection. } \\
\hline $\begin{array}{l}\text { Vitex peduncularis Wall. ex Schauer } \\
\text { in A. DC. }\end{array}$ & Lamiaceae & Thingkhawilu & Tree & LR & $\mathrm{B}$ \\
\hline \multicolumn{6}{|c|}{ Boiled B water is drunk to treat typhoid \& malarial fevers. } \\
\hline Vitis bracteolata Wall. & Vitaceae & Hruiveikual & Climber & LR & $\mathrm{R}$ \\
\hline \multicolumn{6}{|c|}{ Crushed R are used to produce a mucous substance that is applied externally on swellings \& sciatica. } \\
\hline Woodfordia fruticosa (L.) Kurz & Lythraceae & Ainawn & Shrub & CR/VU & $\mathrm{F}$ \\
\hline \multicolumn{6}{|c|}{ Powdered $\mathrm{F}$ are used externally to treat sores \& ulcers. } \\
\hline Xylia xylocarpa Taub. & Fabaceae & Thinguk & Tree & LR & $B, S$ \\
\hline \multicolumn{6}{|c|}{$\begin{array}{l}\text { A B decoction is used to treat ulcers, gonorrhoea \& diarrhoea. S oil is used to treat rheumatism \& piles. B \& S oil are } \\
\text { used to treat leprosy. }\end{array}$} \\
\hline Zanonia indica L. & Cucurbitaceae & $\begin{array}{l}\text { Lalruanga- } \\
\text { dawibur }\end{array}$ & Climber & CR/EN & $\mathrm{Fr}, \mathrm{L}$ \\
\hline \multicolumn{6}{|c|}{$\begin{array}{l}\mathrm{L} \text { are used to treat inflammation \& spasms. Fr is used as an expectorant, antiseptic \& to treat cough \& asthma. Water } \\
\text { from boiled ripened Fr is taken to treat stomach problems. }\end{array}$} \\
\hline Zanthoxylum armatum DC. & Rutaceae & Arhrikreh & Small tree & NT & $\mathrm{Fr}, \mathrm{L}$ \\
\hline \multicolumn{6}{|c|}{$\begin{array}{l}\mathrm{L} \text { are used to remove lice. } \mathrm{Fr} \text { is used to promote appetite, treat headaches, asthma, leucoderma, piles, eye \& ea } \\
\text { diseases, \& is used as an antihelminthic. } \mathrm{F} \text { is used as an antidote for snake bite. }\end{array}$} \\
\hline Zingiber officinale Roscoe & Zingiberaceae & Sawhthing & Herb & NT/C & Fr,Rh \\
\hline \multicolumn{6}{|c|}{ Oil extract is used to treat cough \& bronchitis. Rh is roasted \& eaten to treat throat pain. } \\
\hline Zingiber purpureum Roscoe & Zingiberaceae & Pale & Herb & NT/C & $\mathrm{Rh}$ \\
\hline \multicolumn{6}{|c|}{ Chakmas tribe use Rh to treat stomach ache \& diarrhoea. } \\
\hline Ziziphus mauritiana Lam. & Rhamnaceae & Borai & Small tree & LR & $\mathrm{R}$ \\
\hline
\end{tabular}

\section{Lower Risk (LR) / Near Threatened (NT)}

Gardenia coronaria Buch.-Ham. is LR in Mizoram according to our study which was in accordance with Gardenia gummifera L.f., which is also of LR status. Woodfordia fruticosa (L.) Kurz is LR, however, based on our study it would be categories as EN/VU. Adhatoda zeylanica Medik. is LR, however, Adhatoda beddomei C.B.Clarke, is of CR status globally as well as in south Western Ghats of India. Artocarpus lakoocha Wall. ex Roxb. is LR at a regional scale in NE India and Mizoram, however, $A$. hirsutus is VU at the global scale. Similarly S. asoca, Tinospora cordifolia (Willd.) Miers and Terminalia sp. are all listed as LR.

Burning of Holi, a religious tradition in India, has led to over-exploitation of $B$. ceiba, one of the important medicinal plant species of India (Jain et al. 2007). In our study area, $B$. ceiba is threatened due to land use change in the form of shifting cultivation.

\section{Discussion}

\section{Plants used in diet and health}

Many plants mentioned in Table 3 form an essential dietary component for tribal peoples in the form of vegetables or as an additive to impart flavor. Medicinal plants are of particular relevance when they are components of diet. According to Etkin \& Ross (1991) the priority for further study should be given to plants that are also used in the diet, since the potential health impact is markedly greater for plants used in diet and medicine. Certain herbs like Amaranthus paniculatus L., Aerva lanata (L.) Juss. ex Schult., Coccinia grandis (L.) Voigt and Coriandrum sativum $\mathrm{L}$. are used as vegetables indicating that these plants 
could be sources of dietary antioxidant supplies, which is an emerging area of research (Ali et al. 2008). Antioxidants help organisms deal with oxidative stress, caused by free radical damage. Scartezzini \& Speroni (2000) have reviewed the antioxidant activity of the traditional Indian medicinal plants: C. longa, Mangifera indica L., Momordica charantia L., P. emblica, Santalum album L., S. chirayita, and W. somnifera. Govindarajan et al. (2003) have reviewed Acorus calamus L., A. vera, Andrographis paniculata (Burm. f.) Nees, $A$. racemosus, $A$. indica, $B$. monnieri, Desmodium gangeticum (L.) DC., Glycyrrhiza glabra L., P. kurroa, Psoralea corylifolia L., Semecarpus anacardium L.f., Terminalia chebula Retz., T. cordifolia. Ali et al. (2008) in his review on antioxidant activity of Indian medicinal plants included $A$. lanata, $A$. paniculatus, Aristolochia bracteolata Lam., Cissampelos pareira L., C. indica, C. sativum, Coscinium fenestratum Colebr., C. dactylon, Cyperus rotundus L., Enicostemma littorale Blume, Evolvulus alsinoides (L.) L., Fagonia cretica L., Gymnema montanum (Roxb.) Hook. f., Hygrophila auriculata Heine, Phyllanthus amarus Schumach. \& Thonn., P. debilis, Phyllanthus maderaspatensis L., Phyllanthus niruri L., Rubia cordifolia L., and Trichopus zeylanicus Gaertn. The majority of these same plants are being used in Mizoram and therefore the same potential value as antioxidants is likely to be functioning as well.

\section{Herbal-based industry in Mizoram}

The availability of more than 300 medicinal plant species in Mizoram (Lalramnghinghlova 1999d, 2000, 2001, Lalramnghinghlova \& Jha 1997, Lalramnghinghlova et al. 1997, Rai 2010a,b, Rai 2011a,b, Singh et al. 2002) has potential for herbal-based industries. At present, besides local health care, these medicinal plants are the alternative income-generating source of the rural populations living in hilly areas. Biotechnological approaches should be implemented for clonally produced plants and their success in the natural environment. Moreover, in tribal areas of Mizoram, conventional methods of rural technology for cultivation of these rare medicinal plants should be promoted to reduce the pressure on the wild resources. There is also a need to involve local people and the indigenous practices developed by them for sustainable utilization of surrounding natural resources, so that the present pressures may be mitigated.

\section{Concluding Remarks}

Over the last century, ethnobotany has evolved into a specific discipline that looks at the people-plant relationship in a multidisciplinary manner, including perspectives from ecology, economic botany, pharmacology, public health and other disciplines as needed (Ayyanar \& Ignacimuthu 2005, Balick \& Cox 1996). However, the traditional knowledge system in India is fast eroding (Sinha 1996). If immediate steps are not taken for their conservation and sustainable utilization the species discussed herein are threatened.

Further, adequate caution should be taken to categorize the threatened status at regional scale (Arvind et al. 2005). The ethnomedicinal plants should be cultivated in herbal gardens, agroforestry systems and home gardens to encourage their sustainable utilization and hence conservation. Assessment of the populations of threatened species, development of an appropriate strategy, action plan for the conservation and sustainable utilization of such components of plant diversity are recommended (Samant \& Pant 2006). The ethnobotanical claims emanating from the present survey need to be subjected to pharmaco-chemical studies in order to discover their true potential.

\section{Acknowledgements}

The authors are thankful to University Grants Commission (UGC) and Department of Science and Technology, Government of Mizoram for financial assistance to HLR. Also, HLR is thankful to Environment and Forest Department, Government of Mizoram and Professor L.K. Jha for providing all sort of cooperation during his work as Forest Botanist. The authors also extend their regard to Professor A.N. Rai, Vice Chancellor, Mizoram University, for his kind co-operation and support.

\section{Literature Cited}

Agarwal, V.S. 1997. Drug Plants of India. Volume I. Kalyani Printers, New Delhi.

Akerele O., V. Heywood \& H. Synge. 1991. Editors of The Conservation of Medicinal Plants. Proceedings of an International Consultation 21-27 March 1988 in Chiang Mai, Thailand. Cambridge University Press, Cambridge.

Ali, S.S., N. Kasoju, A. Luthra, A. Singh, H. Sharanabasava, A. Sahu \& U. Bora. 2008. Indian medicinal herbs as sources of antioxidants. Food Research International 4:115.

Ali, Z.A. 1999. Folk veterinary medicine in Moradabad District (Uttar Pradesh), India. Fitoterapia 70:340-347.

Allendorf, F.W., D. Bayles, D.L. Bottom, K.P. Currens, C.A. Frissell, D. Hankin, J.A. Lichatowich, W. Nehlsen, P.C. Totter \& T.H. Williams. 1997. Prioritizing Pacific salmon stock for conservation. Conservation Biology 11:140-152.

Alok, S.K. 1991. Medicinal plants in India: Approaches to exploitation and conservation. Pp. 295-303 in The Conservation of Medicinal Plants. Edited by O. Akerele, V. Heywood \& H. Synge. Proceedings of an International 


\section{Rai \& Lalramnghinglova - Ethnomedicinal Plants of India with Special Reference to an Indo-Burma Hotspot Region: An overview}

Consultation 21-27 March 1988 in Chiang Mai, Thailand. Cambridge University Press, Cambridge.

Anyinam, C. 1995. Ecology and ethnomedicine: Exploring links between current environmental crisis and indigenous medical practices. Social Science and Medicine 40(3):321-329.

Aravind, N.A., J. Manjunath, D. Rao, K.N. Ganeshaiah, R. Uma Shaanker \& G. Vanaraj. 2005. Are red-listed species threatened? A comparative analysis of red-listed and nonred-listed plant species in the Western Ghats, India. Current Science 88(2):258-265.

Arora, R. \& S.S. Bhojwani. 1989. In vitro propagation and low temperature storage of Saussurea lappa C.B. Clarke: An endangered medicinal plant. Plant Cell Reports 8:4447.

Ayyanar, M. \& S. Ignacimuthu. 2005. Traditional knowledge of Kani tribals in Kouthalai of Tirunelveli hills, Tamil Nadu, India. Journal of Ethnopharmacology 102:246-255.

Azaizeh, H., S. Fulder, K. Khalil \& O. Said. 2003. Ethnomedicinal knowledge of local Arab practitioners in the Middle East Region. Fitoterapia 74:98-108.

Bagavan, A., A.A. Rahuman, C. Kamaraj \& K. Geetha. 2008. Larvicidal activity of saponin from Achyranthes aspera against Aedes aegypti and Culex quinquefasciatus (Diptera: Culicidae). Parasitology Research 103:223229.

Baillie, J.E.M., C. Hilton-Taylor \& S.N. Stuart. 2004. Editors of How Many Threatened Plants are There? A Global Species Assessment. The IUCN Species Survival Commission. The IUCN Species Programme, Gland, Switzerland.

Bajaj, Y.P.S., M. Furmanowa \& O. Olszowska. 1988. Biotechnology of the micropropagation of medicinal and aromatic plants. Pp. 60-103 in Biotechnology in Agriculture and Forestry. Volume 4. Edited by Y.P.S. Bajaj. Springer Verlag, New York.

Balick, M.J. \& P.A. Cox 1996. Plants, People, and Culture: The science of ethnobotany. Scientific American, New York.

Ball, K. 1986. Ladakh A. Happy People- But for how long? The Lancet 327(8473):145-146.

Ballabh, B. \& O.P. Chaurasia. 2007. Traditional medicinal plants of cold desert Ladakh-used in treatment of cold, cough and fever. Journal of Ethnopharmacology 112:341349 .
Ballabh, B., O.P. Chaurasia, Z. Ahmed \& S.B. Singh. 2008. Traditional medicinal plants of cold desert Ladakh-used against kidney and urinary disorders. Journal of Ethnopharmacology 118:331-339.

Balmford, A. \& A. Long. 1995. Across country analyses of biodiversity congruence and current conservation effort in the tropics. Conservation Biology 9:1539-1547.

Bennet, S.S.R. 1983. Ethnobotanical studies in Sikkim. Indian Forester 109:577-581.

Bhagyalakshmi N. \& N.S. Singh. 1988. Meristem culture and micropropagation of a variety of ginger (Zingiber officinale Rosc.) with a high yield of Oleoresin. Journal of Horticulture Science 63(2):321-7.

Bhatia, A.L. \& M. Jain. 2003. Amaranthus paniculatus (Linn.) improves learning after radiation stress. Journal of Ethnopharmacology 85:73-79.

Bhogaonkar, P.Y. \& V.D. Devarkar. 2002a. Some unique ethnomedicinal plants of Korkus of Melghat Tiger Reserve (Maharashtra). Ethnobotany 14:16-19.

Bhogaonkar, P.Y. \& V.D. Devarkar. 2002b. Pharmacognostic studies in some asteraceous ethnomedicinal plants of Korkus of Melghat, Distt.-Amravati (M.S.). Bhaskaracharya Research Institute's Journal of Advances in Science and Technology 5:28-32.

Bisht, A.K., A. Bhatt, R.S. Rawal \& U. Dhar. 2006. Prioritization and conservation of Himalayan medicinal plants: Angelica glauca Edgew. as a case study. Ethnobotany Research \& Applications 4:11-23.

Biswas, K. 1956. Common Medicinal Plants of Darjeeling and Sikkim Himalaya. Bengal Government Press, West Bengal, Calcutta.

Bopana, N. \& S. Saxena. 2007. Asparagus racemosus - Ethnopharmacological evaluation and conservation needs. Journal of Ethnopharmacology 110:1-15.

Bunker S.G. 1985. Understanding the Amazon: Extraction, unequal exchange, and the failure of the modern state. University of Chicago Press, Chicago.

Buragohain, J. 2008. Folk medicinal plants used in gynecological disorders in Tinsukia district, Assam, India. Fitoterapia 79:388-392.

Burkill, I.H. 1935. A Dictionary of the Economic Products of the Malay Peninsula. Crown Agents for the Colonies Calixto, London.

Carneiro, R.L. 1988. Indians of the Amazonian forest. Pp. 73-86 in People of the Tropical Rainforest. Edited by 
J.S. Denslow \& C. Padoch. University of California Press, Berkeley.

Chandler, R.F., L. Freeman \& S.N. Hopper. 1979. Herbal remedies of maritime Indians. Journal of Ethnopharmacology 1:49-54.

Chatterjee S. \& S. Dey. 1997. A preliminary survey of Taxus baccata var wallichiana in Tawang district of Arunachal Pradesh. The Indian Forester 123:746-754.

Chaudhuri, A.B. 2007. Endangered Medicinal Plants. Daya Publishing House, New Delhi.

Chaudhari, U.S. \& V. Hutke. 2002. Ethno-medico-botanical information on some plants used by Melghat tribes of Amravati District, Maharashtra. Ethnobotany 14:100-102.

Chhetri, D.R., S. Parajuli \& J. Adhikari. 2008. Antihepatopathic Plants Used by the Lepcha Tribe of the Sikkim and Darjeeling Himalayan Region of India. Journal of Herbs, Spices \& Medicinal Plants 13(3):27-35.

Chhetri, D.R., P. Parajuli \& G.C. Subba. 2005. Antidiabetic plants used by Sikkim and Darjeeling Himalayan tribes, India. Journal of Ethnopharmacology 99:199-202.

Conservation International. 2005. Biodiversity Hotspots. Conservation International, Washington, DC. www.biodiversityhotspots.org/xp/Hotspots/. Accessed 16 November, 2008.

Corduan, G. \& C. Spix. 1975. Haploid callus and regeneration of plants from anthers of Digitalis purpurea L. Planta 124:1-11.

Daniels, R.J.R., M. Gadgil \& N.V. Joshi. 1995. Impact of human extraction on tropical humid forests in the Western Ghats in Uttara Kannada, South India. Journal of Applied Ecology 32:866-874.

Das, A.P. \& S. Mandal. 2003. Some Medicinal Plants of Darjeeling Hills. World Wildlife Fund-India. West Bengal State Office, Kolkata.

Das, S., S. Das, S. Paul, A. Mujib \& S. Dey. 1999. Biotechnology of medicinal plants: Recent advances and potential. Pp. 126-139 in Role of Biotechnology in Medicinal and Aromatic Plants. Volume 2. Edited by I.A. Khan \& A. Khanum. Ukaaz Publications, Hyderabad, India.

Denevan W.M. 1976. The aborigninal population of Amazonia. Pp. 205-234 in The Native Population of the Americas in 1492. Edited by W.M. Denevan. University of Wisconsin Press, Madison, Wisconsin.
Dhar, U. 2002. Conservation implications of plant endemism in high-altitude Himalaya. Current Science 82:141148.

Dhar, U., R.S. Rawal \& J. Upreti. 2000. Setting priorities for conservation of medicinal plants- A case study in the Indian Himalaya. Biological Conservation 95:57-65.

Dhar, U., S. Manjkhola, M. Joshi, A. Bhatt, A.K. Bisht \& M. Joshi. 2002. Current status and future strategy for development of medicinal plants sector in Uttaranchal, India. Current Science 83:956-964.

Diaz, J.L. 1977. Ethnopharmacology of sacred-psycoactive plants used by the Indians of Mexico. Annual Review of Pharmacology and Toxicology 17:647-675.

Diehl, M.S., K.K. Atindehou, H. Tere \& B. Betschart. 2004. Prospect for anthelminthic plants in the Ivory Coast using ethnobotanical criteria. Journal of Ethnopharmacology 95 (2-3):277-284.

Dixit-Sharma, S., S. Ahuja-Ghosh, B.B. Mandal \& P.S. Srivastava. 2005. Metabolic stability of plants regenerated from cryopreserved shoot tips of Dioscorea deltoidea - An endangered medicinal plant. Scientia Horticulturae 105:513-517.

Duraipandiyan, V. \& S. Ignacimuthu. 2007. Antibacterial and antifungal activity of Cassia fistula L.: An ethnomedicinal plant. Journal of Ethnopharmacology 112:590-594.

Etkin, N.L. \& P.J. Ross. 1991. Should We Set a Place for Diet in Ethnopharmacology? Journal of Ethnopharmacology 32:25-36.

Fairbairn, J.W. 1980. Perspective in research on active principles of traditional herbal medicines, a botanical approach: Identification and supply of herbs. Journal of Ethnopharmacology 2:99-106.

Faisal, M. \& M. Anis. 2007. Regeneration of plants from alginate-encapsulated shoots of Tylophora indica (Burm. f.) Merrill, an endangered medicinal plant. Journal of Horticultural Science and Biotechnology 82(3):351-354.

Farnsworth, N.R., O. Akerele \& A.S. Bingel. 1985. Medicinal plants in therapy. Bulletin of the World Health Organisation 63:965-981.

Farooquee N.A. 1994. Transhumance in the Central Himalaya: A study of its impact on environment. Ph.D. Thesis. Hemwati Nandan Bahuguna Garhwal University, Srinagar, India.

Farooquee N.A. \& A. Nautiyal. 1999. Traditional knowledge and practices of Bhotiya pastoralists of Kumaon Hi- 


\section{Rai \& Lalramnghinglova - Ethnomedicinal Plants of India with Special Reference to an Indo-Burma Hotspot Region: An overview}

malaya: The need for value addition. International Journal of Sustainable Development and World Ecology 6:60-67.

Farooquee, N.A. \& K.G. Saxena. 1996. Conservation and utilization of medicinal plants in high hills of central Himalaya. Environmental Conservation 23:75-80.

Franz, C. 1993. Domestication of wild growing medicinal plants. Plant Research and Development 37:101-111.

Gadgil, M. 1996. Documenting diversity: An experiment. Current Science 70 (1): 36-44.

Gaur, R.D. 1999. Flora of the District Garhwal Northwest Himalaya (with ethnobotanical notes). TransMedia, Srinagar Garhwal, India.

George, E.F. \& P.D. Sherrington. 1984. Pp. 39-71 in Plant Propagation by Tissue Culture. Exegetics Ltd., Eversley, England.

Gesler, W.M. 1992. Therapeutic landscapes: Medical Issues in Light of the new cultural geography. Social Science and Medicine 34:735.

Ghosh, B. \& S. Sen. 1989. Somatic embryos in Asparagus cooperi Baker. Current Science 58:256-257.

Giri, A., S. Banerjee, P.S. Ahuja \& C.C. Giri. 1997. Production of hairy roots in Aconitum heterophyllum Wall. using Agrobacterium rhizogenes. In Vitro Cellular and Developmental Biology Plant 33(4):293-296.

Good, C. 1980. Ethno-medical systems in Africa and the LDCs: Key issues in medical geography. Pp. 93-116 in Conceptual and Methodological Issues in Medical Geography. Studies in Geography 5. Edited by M.S. Meade. University of North Carolina, Chapel Hill, NorthCarolina.

Govindarajan, R., S. Rastogi, M. Vijayakumar, A.K.S. Rawat, A. Shirwaikar, S. Mehrotra \& P. Pushpangadan. 2003. Studies on the antioxidant activities of Desmodium gangeticum. Biological and Pharmaceutical Bulletin 26:1424-1427.

Guha, S. \& S.C. Maheshwari.1964. In vitro production of embryos from anthers of Datura. Nature 204:297.

Hebbar, S.S., V.H. Harsha, V. Shripathi \& G.R. Hegde. 2004. Ethnomedicine of Dharwad district in Karnataka, India - Plants used in oral health care. Journal of Ethnopharmacology 94:261-266.

Hecht S. \& A. Cockburn. 1989. The Fate of the Forest: Developers, destroyers, and defenders of the Amazon. Verso, London.
Heinrich, M., S. Edwards, D.E. Moerman \& M. Leonti. 2009. Ethnopharmacological field studies: A critical assessment of their conceptual basis and methods. Journal of Ethnopharmacology 124:1-17

Heywood, V.H. 1995. Global Biodiversity Assessment. Cambridge University Press, Cambridge, U.K.

Houghton, P. 2007. Book Review (Ethnopharmacology of Medicinal Plants: Asia and the Pacific). British Journal of Clinical Pharmacology 64(2):248.

Howard, P.C., P. Viskanic, T.R.B. Davenport, F.W. Kigenyi, M. Baltzer, C.J. Dickinson, J.S. Lwanga, R.A. Matthews \& A. Balmford. 1998. Complementarity and the use of indicator groups for reserve selection in Uganda. Nature 394:472-475.

Hu, C.Y. \& P.J. Wang. 1983. Meristem, shoot-tip and bud culture. Pp. 177-277 in Handbook of Plant Cell Culture. Volume 1. Edited by D.A. Evans, W.R. Wang, P.V. Ammirato \& Y. Yamada. MacMillan, New York.

Ignacimuthu, S., M. Ayyanar \& M. Sankarasivaraman. 2008. Ethnobotanical study of medicinal plants used by Paliyar tribals in Theni district of Tamil Nadu, India. Fitoterapia 79(7-8):562-568.

IUCN. 1994. IUCN Red List Categories. Prepared by the IUCN Species Survival Commission. IUCN, Gland, Switzerland.

IUCN. 2003. Guidelines for Application of IUCN Criteria at Regional Levels. Version 3.0. IUCN.

IUCN. 2007a. CITES News: Trade review of seven Asian CITES medicinal species. Newsletter of the Medicinal Plant Specialist Group of the IUCN Species Survival Commission 13:23.

IUCN. 2007b. SSC. The IUCN Red List of Threatened species. 1994-2007 version. Gland, Switzerland. www. iucnredlist.org.

IUCN. 2009. IUCN Red List of Threatened Species. Version 2009.1. Gland, Switzerland. www.iucnredlist.org.

Iwu, M.M. 1993. Handbook of African Medicinal Plants. CRC Press, Boca Rotan, Florida.

Jagtap S.D., S.S. Deokule \& S.V. Bhosle. 2006. Some unique ethnomedicinal uses of plants used by the Korku tribe of Amravati district of Maharashtra, India. Journal of Ethnopharmacology 107:463-469.

Jain, A., S.S. Katewa, P.K. Galav \& P. Sharma. 2005. Medicinal plant diversity of Sitamata wildlife sanctuary, Ra- 
jasthan, India. Journal of Ethnopharmacology 102:143157.

Jain, S.K. 1964. The role of botanist in folklore research. Folklore 5:145-150.

Jain, S.K. \& N. Dam. 1979. Some ethnobotanical notes from northeastern India. Economic Botany 33(1):52-56.

Jain, V., S.K. Verma \& S.S. Katewa. 2007. A dogmatic tradition posing threat to Bombax ceiba - the Indian Red Kapok Tree. Taxon file, Medicinal Plant Conservation. Newsletter of the Medicinal Plant Specialist Group of the IUCN Species Survival Commission 13:12-14.

Jamir, S.A. \& H.N. Pandey. 2002. Status of biodiversity in the sacred groves of Jaintia hills, Meghalaya. The Indian Forester 128:738-744.

Jamir, S.A. \& H.N. Pandey. 2003. Vascular plant diversity in the sacred groves of Jaintia hills in northeast India. Biodiversity and Conservation 12:1497-1510.

Jamir, T.T., H.K. Sharma \& A.K. Dolui. 1999. Folklore medicinal plants of Nagaland, India. Fitoterapia 70:395-401.

Jolly, A. \& G. Landting. 1987. Man against nature: Time for a truce in Madagascar. National Geographic 171:160.

Kala, C.P. 2000. Status and conservation of rare and Endangered medicinal plants in the Indian trans-Himalaya. Conservation Biology 93:371-379.

Kala, C.P. 1998a. Ethnobotanical Survey and Propagation of Rare Medicinal Herbs for Small Farmers in the Buffer Zone of the Valley of Flowers National Park, Garhwal Himalaya. A Report. ICIMOD, Kathmandu, Nepal.

Kala, C.P. 1998b. Ecology and Conservation of Alpine Meadows in the Valley of Flowers National Park, Garhwal Himalaya. Ph.D. Thesis, Forest Research Institute, Dehradun, India.

Kala, C.P. 2000. Status and conservation of rare and endangered medicinal plants of Indian trans- Himalaya. Biological Conservation 93:371-379.

Kala, C.P. 2002a. Indigenous knowledge of Bhotiya tribal community on wool dying and its present status in the Garhwal Himalaya, India. Current Science 83: 814-817.

Kala, C.P. 2002b. Medicinal Plants of Indian Trans-Himalaya. Bishen Singh Mahendra Pal Singh, Dehradun, India.

Kala, C P. 2005. Indigenous uses, population density, and conservation of threatened medicinal plants in protected areas of the Indian Himalayas. Conservation Biology 19:368-378.
Kala, C.P., A. Nehal, A. Farooquee \& U. Dhar. 2004. Prioritization of medicinal plants on the basis of available knowledge, existing practices and use value status in Uttaranchal, India. Biodiversity and Conservation 13:453469.

Kala, C.P. \& B.S. Sajwan. 2007. Revitalizing Indian systems of herbal medicine by the national medicinal plants board through institutional networking and capacity building. Current Science 93(6):797-806.

Kareem Abdul, M. 1997. Plants in Ayurveda, A compendium of botanical and Sanskrit names. Foundation for Revitalization of Local Health Traditions, Bangalore, India.

Katewa, S.S. 2009. Indigenous people and forests: Perspectives of an ethnobotanical study from Rajasthan (India). Pp. 33-56 in Herbal Drugs: Ethnomedicine to modern medicine. Edited by K.G. Ramawat. Springer-Verlag, Heidelberg.

Katewa, S.S., B.D. Guria \& A. Jain. 2001. Ethnomedicinal and obnoxious grasses of Rajasthan India. Journal of Ethnopharmacology 76:293-297.

Katewa, S.S., B.L. Chaudhary \& A. Jain. 2004. Folk herbal medicines from tribal area of Rajasthan, India. Journal of Ethnopharmacology 92:41-46.

Katewa, S.S. \& R. Sharma. 1998. Ethnomedicinal observation from certain watershed areas of Rajasthan. Ethnobotany 10:46-49.

Kaufman, D.G. \& C.M. Franz. 1993. Biosphere 2000: Protecting our global environment. Harper Collins College Publishers.

Kayang, H. 2007. Tribal knowledge on wild edible plants of Meghalaya, North-east India. Indian Journal of Traditional Knowledge 6(1):177-181.

Kitto, S.L. \& J. Janick. 1982. Polyox as an artificial seed coat for sexual embryos. Horticulture Science 17:448.

Koblitz, H., H. Koblitz, H.P. Schmauder \& D. Groger. 1983. Studies on tissue cultures of the genus Cinchona L. Plant Cell Reports 2: 95-97.

Kshirsagar, R.D. \& N.P. Singh. 2001. Some less known ethnomedicinal uses from Mysore and Coorg districts, Karnataka state, India. Journal of Ethnopharmacology 75:231-238.

Kumar, S. 1997. India wins battle with USA over turmeric patent. Lancet 350:724. 


\section{Rai \& Lalramnghinglova - Ethnomedicinal Plants of India with Special Reference to an Indo-Burma Hotspot Region: An overview}

Kumar, V. 2006. Potential medicinal plants for CNS disorders: An overview. Phytosynthesis Research 20(12):1023-1035.

Kumaran, A. \& R.J. Karunakaran. 2007. In vitro antioxidant activities of methanol extracts of five Phyllanthus species from India LWT. Food Science and Technology 40:344-352

Laloo, R.C., L. Kharlukhi, S. Jeeva \& B.P. Mishra. 2006. Status of medicinal plants in the disturbed and undisturbed sacred forest of Meghalaya, Meghalaya, Northeast India: Population structure and regeneration efficacy of some important species. Current Science 90 (2): 225-232.

Lalramnghinghlova, H. 1999a. Prospects of ethnomedicinal plants of Mizoram in the new millennium. Pp. 119-126 in Proceedings of the Symposium on Science and Technology for Mizoram in 21st Century, 17-18 June, 1999. Aizawl, India.

Lalramnghinghlova, H. 1999b. Ethnobotany: A review. Journal of Economic and Taxonomic Botany 23(1):1-27.

Lalramnghinghlova, H. 1999c. Ethnobotanical and agroecological studies on genetic resources of food plants in Mizoram state. Journal of Economic and Taxonomic Botany 23(2):637-644.

Lalramnghinghlova, H. 1999d. Status paper on bamboo in Mizoram. Arunachal Forest News 17(1\&2):34-37.

Lalramnghinghlova, H. 2000. Ethnomedicinal plants development in Mizoram. Pp. 395-404 in Proceedings of the International Workshop on Agroforestry and Forest Products, Aizawl, November, 28-30, 2000. Department of Forestry, North Eastern Hill University, Mizoram Campus, Aizawl, India.

Lalramnghinghlova, H. 2001. Ethnobotanical interpretations and future prospects of ethnobotany in the NorthEast India. Science Vision 1:24-31.

Lalramnghinghlova, H. 2002a. Bioresources of Mizoram: An overview. Journal of the North Eastern Council 56-64.

Lalramnghinghlova, H. 2002b. Ethnobotanical study on the edible plants of Mizoram. Ethnobotany 14:23-33.

Lalramnghinghlova, H. 2003. Ethnomedicinal Plants of Mizoram. Bishen Singh Mahendra Pal Singh, Dehra Dun, India.

Lalramnghinghlova, H. \& L.K. Jha. 1997. Forest Resources: An overview. Pp. 203-255 in Natural Resource Management. Volume I. Edited by L.K. Jha, S.B. Nangia. A.P.H. Publishing Corporation, New Delhi.
Lalramnghinghlova, H. \& L.K. Jha. 1998. Ethnomedicinal plants among the hill tribes of Mizoram. Pp. 67-86 in Prospects of Medicinal Plants. Edited by P.L. Gautam, R. Raina, U, Srivastava, S.P. Raychaudhari \& B.B. Singh. Indian Society of Plant Genetic Resources, New Delhi.

Lalramnghinghlova, H. \& L.K. Jha. 1999. New records of ethnomedicinal plants from Mizoram. Ethnobotany 11: 5764.

Lalramnghinghlova, H., R. Mohan \& L.K. Jha. 1997. Ethno-phytomedicinal practice in Mizoram (NE India) based on indigenous classification of diseases. Pp. 195-200 in Proceedings of the National Conference on Health Care and Development of Herbal Medicines, August 29-30, 1997. Indira Gandhi Agricultural University, Raipur, India.

Lange, D. 1997. Trade figures for botanical drugs worldwide. Medicinal Plant Conservation Newsletter 3:16-17.

Lans, C., K. Georges \& G. Brown. 2007. Non-experimental validation of ethnoveterinary plants and indigenous knowledge used for backyard pigs and chickens in Trinidad and Tobago. Tropical Animal Health and Production 39(5):375-385

Larsen, H.O., C.S. Olsen \& T.E. Boon. 2000. The non-timber forest policy process in Nepal: Actors, objectives and power. Forest Policy and Economics 1:267-281.

Lewis, M.P. 2009. Editor of Ethnologue: Languages of the world. Sixteenth edition. SIL International, Dallas, Texas.

Lewis, W.H., E.J. Kennelly, G.N. Bass, H.J. Wedner, M.P. Elvin-Lewis \& D. Fast. 1991. Ritualistic use of the holly Ilex guayusa by Amazonian Jívaro Indians. Journal of Ethnopharmacology 33(1-2):25-30.

Mace, G.M. \& R. Lande. 1991. Assessing extinction threats towards re-evaluation of IUCN threatened species categories. Conservation Biology 5:148-157.

Macías, F.A., J.L.G. Galindo \& J.C.G. Galindo. 2007. Evolution and current status of ecological phytochemistry. Phytochemistry 68:2917-2936.

Mahishi, P., B.H. Srinivasa \& M.B. Shivanna. 2005. Medicinal plant wealth of local communities in some villages in Shimoga District of Karnataka, India. Journal of Ethnopharmacology 98:307-312.

Maikhuri R.K., S. Nautiyal, K.S. Rao \& K.G. Saxena. 1998. Medicinal plants cultivation and biosphere reserve management: A case study from Nanda Devi Biosphere Reserve, Himalaya. Current Science 74:157-163.

Maikhuri R.K., S. Nautiyal, K.S. Rao \& R.L. Semwal. 2000. Indigenous knowledge of medicinal plants and wild 
edibles among three tribal sub-communities of the Central Himalayas, India. Indigenous Knowledge and Development Monitor 8:7-13.

Marshall, N. 1997. First formal MPSG meeting held on 5 September 1996, Nairobi, Kenya. Medicinal Plant Conservation Newsletter 3:3-5.

Martinez, H.P. 1995. Commercialisation of wild medicinal plants from Southwest Pueblo Mexico. Economic Botany 49:197-206

Martinez, H.P. 1997. Medicinal plants and regional traders in Mexico: physiographic differences and conservation challenge. Economic Botany 51:107-120.

McClatchey, W.C., G.B. Mahady, B.C Bennett, L. Shiels \& V. Savo. 2009. Ethnobotany as a pharmacological research tool and recent developments in CNS-active natural products from ethnobotanical sources. Pharmacology \& Therapeutics 123:239-254.

Mishra, B.P., O.P. Tripathi, R.S. Tripathi \& H.N. Pandey. 2004. Effects of anthropogenic disturbance on plant diversity and community structure of a sacred grove in Meghalaya. North-east India. Biodiversity Conservation 13:421436.

Mittermeier, R.A., P.R. Gil, M. Hoffmann, J. Pilgrim, T. Brooks, C.G. Mittermeier, J. Lamoreux \& G.A.B. da Fonseca. 2004. Hotspots Revisited: Earth's biologically richest and most endangered terrestrial ecoregions. CEMEX (Conservation International Mexico)/Agrupación Sierra Madre, Mexico City, Mexico.

Mukherjee, P.K., B. Suresh \& R. Verpoorte. 2001. CNS active potentials of some Hypericum species of India. Phytomedicine 8: 331-337.

Mulliken, T. \& U. Schippmann. 2007. CITES medicinal plant species in Asia - treasured past, threatened future? Newsletter of the Medicinal Plant Specialist Group of the IUCN Species Survival Commission 13:23-31.

Murashige T. 1977a. Plant cell and organ cultures as horticultural practices. Acta Horticulturae 78:17.

Murashige, T. 1977b. Manipulation of organ culture in plant tissue cultures. Botanical Bulletin Academica Sinica 18:1-24.

Muthuvelan, B. \& R.B. Raja. 2008. Studies on the efficiency of different extraction procedures on the anti microbial activity of selected medicinal plants. World Journal of Microbiology Biotechnology 24:2837-2842.

Myers, N. 1988. Threatened biotas: "hot-spots" tropical forests. The Environmentalists 8:178-208.
Myers, N., R.A. Mittermeier, G.C. Mittermeier, G.A.B. da Fonseca \& J. Kent. 2000. Biodiversity hotspots for conservation priorities. Nature 403:853-858.

Naina, N.S., P.K. Gupta \& A.F. Mascarenhas. 1989. Genetic transformation and regeneration of transgenic neem (Azadirachta indica) plants using Agrobacterium tumefaciens. Current Science 58:184-187.

Nautiyal S., K.S. Rao, R.K. Maikhuri, R.L. Semwal \& K.G. Saxena. 2000. Traditional knowledge related to medicinal and aromatic plants in tribal societies in a part of Himalaya. Journal of Medicinal and Aromatic Plant Sciences 22/4A and 23/1A:528-441.

Navchoo, I.A. \& G.M. Buth. 1989. Medicinal system of Ladakh, India. Journal of Ethnopharmacology 26(2):137146.

Nayar M.P. \& A.R.K. Sastry. 1987. Red Data Book of Indian Plants. Volumes 1-3. Botanical Survey of India, Calcutta, India.

Nayar, M.P. \& A.R.K. Sastry. 1990. Red Data Book of Indian Plants. Volumes 1-3. Botanical Survey of India, Calcutta, India.

Negi, H.R. \& M. Gadgil. 2002. Cross-taxon surrogacy of biodiversity in the Indian Garhwal Himalaya. Biological Conservation 105:143-155.

Oliver, I. \& A.J. Beattie. 1993. A possible method for the rapid assessment of biodiversity. Conservation Biology 7:562-567.

Olsen, C.S. 1998. The trade in medicinal and aromatic plants from central Nepal to northern India. Economic Botany 52:279-292.

Oostermeijer, J.G.B., S.H. Luitjen \& J.C.M. Nijs. 2003. Integrating demographic and genetic approaches in plant conservation. Conservation Biology 113:389-398.

Padhye, M.D., V.K. Deshmukh \& V.J. Tiwari. 1991. Ethnobotanical study of Korku tribe of Amravati District, Maharashtra State, India. International Journal of Pharmacognosy 29:1-4.

Padhye, M.D., V.K. Deshmukh \& V.J. Tiwari. 1992. Ethnobotanical study of Korku tribe of Amravati District, Maharashtra State, India. International Journal of Pharmacognosy 30:17-20.

Paliwal, G.S. \& A.K. Badoni. 1990. Ethnobotany of the hill tribes of Uttarkashi; Medicinal plants. Journal of Economic and Taxonomic Botany 14:421-442. 


\section{Rai \& Lalramnghinglova - Ethnomedicinal Plants of India with Special Reference to an Indo-Burma Hotspot Region: An overview}

Pandey, V.N. 1991. Medico-Ethno-Botanical Explorations in Sikkim Himalayas. Central Council for Research in Ayurveda and Siddha, Government of India, New Delhi.

Panwar, J. \& J.C. Tarafdar. 2006. Distribution of three endangered medicinal plant species and their colonization with arbuscular mycorrhizal fungi. Journal of Arid Environments 65:337-350.

Pattanaik, C. \& C.S. Reddy. 2008. Medicinal plant wealth of local communities in Kuldiha Wildlife Sanctuary, Orissa, India. Journal of Herbs, Spices \& Medicinal Plants 14(3):175-184.

Perez-Bermudez, P., M.J. Cornejo \& J. Segura. 1985. Pollen plant formation from anther cultures of Digitalis obscura. Plant Cell Tissue and Organ Culture 5:63-68.

Perry, L.M. with J. Metzger. 1980. Medicinal Plants of East and Southeast Asia: Attributed properties and uses. The MIT Press, Cambridge, Massachusetts.

Phillips, O.L. \& B.A. Meilleur. 1998. Usefulness and economic potential of the rare plants of the United States: A statistical survey. Economic Botany 52:57-67.

Planning Commission. 2000. Report of the Task Force on Conservation and Sustainable use of Medicinal Plants. Planning commission, Government of India, New Delhi.

Pollard, E. \& T.J. Yates. 1993. Monitoring Butterflies for Ecology and Conservation. Chapman and Hall, London.

Pradel, H., U. Dumkelehmann, B. Diettrich\& M. Luckner. 1997. Hairy root cultures of Digitalis lanata. Secondary metabolism and plant regeneration. Journal of Plant Physiology 151:209-15.

Purohit, A.N. 1997. Medicinal plants - Need for upgrading technology for trading the traditions. Pp. 46-76 in Harvesting Herbs - 2000. Edited by A.R. Nautiyal, M.C. Nautiyal \& A.N. Purohit. Bishen Mahendra Pal Singh, Dehradun, India.

Rabinowitz, D., S. Cairns \& T. Dillon. 1986. Seven forms of rarity and their frequency in the flora of British Isles. Pp. 182-204 in Conservation Biology: Science of scarcity and diversity. Edited by M.E. Soule. Sinnauer Associate, Sunderland.

Rahuman, A.A., P. Venkatesan, K. Geetha, G. Gopalakrishnan, A. Bagavan \& C. Kamaraj. 2008. Mosquito larvicidal activity of gluanol acetate, a tetracyclic triterpenes derived from Ficus racemosa Linn. Parasitology Research 103:333-339.
Rai, L.K., P. Prasad \& E. Sharma. 2000. Conservation threats to some important medicinal plants of the Sikkim Himalaya. Biological Conservation 93:27-33.

Rai, L.K. \& E. Sharma. 1994. Medicinal Plants of Sikkim Himalayas - Status uses and potential. Bishen Singh Mahendra Pal Singh, Dehradun, India.

Rai, M.K., P. Asthana, S.K. Singh, V.S. Jaiswal \& U. Jaiswal. 2009. The encapsulation technology in fruit plants - A review. Biotechnological Advances 27:671-679.

Rai, P.C., A. Sarkar, R.B. Bhujel \& A.P. Das. 1998. Ethnomedicinal studies in some fringe areas of Sikkim and Darjeeling Himalaya. Journal of Hill Research 11:12-21.

Rai, P.K. 2009. Comparative assessment of soil properties after bamboo flowering and death in a tropical forest of Indo-Burma hot spot. Ambio 38(2):118-120.

Rai, P.K. 2011b. Assessment of multifaceted environmental issues and model development of an Indo-Burma hotspot region. Environmental Monitoring and Assessment 1-19.

Rai, P.K. \& H. Lalramnghinglova. 2010a. Lesser known ethnomedicinal plants of Mizoram, North East India: An Indo-Burma hotspot region. Journal of Medicinal Plants Research 4(13):1301-1307.

Rai, P.K. \& H. Lalramnghinglova. 2010b. Ethnomedicinal plant resources of Mizoram, India: Implication of traditional knowledge in health care system. Ethnobotanical Leaflets 14:274-305.

Rai, P.K. \& H. Lalramnghinglova. 2010c. Ethnomedicinal plants from agroforestry systems and home gardens of Mizoram, North East India- Review. Herba Polonica 56(2):1-13.

Rai, P.K. \& H. Lalramnghinglova. 2011. Threatened and less known ethnomedicinal plants of an Indo-Burma hotspot region: Conservation implications. Environmental Monitoring and Assessment 178:53-62.

Rai, S.K. \& R.B. Bhujel. 1999. Notes on some less known ethnomedicinal plants from Darjeeling Himalayas. Journal of Hill Research 12:160-163.

Rai, S.K. \& R.B. Bhujel. 2002. Ethnic uses of some monocotyledonous plants in the Darjeeling Himalayan region. Pp. 635-644 in Perspectives of Plant Biodiversity. Edited by A.P. Das. Bishen Singh Mahendra Pal Singh, Dehradun, India.

Rajendran, S.M., S.C. Agarwal \& V. Sundaresan. 2004. Lesser known ethnomedicinal plants of the Ayyakarkoil Forest Province of Southwestern Ghats, Tamil Nadu, In- 
dia-Part I. Journal of Herbs, Spices \& Medicinal Plants 10(4):103-112.

Ramawat, K.G., S. Jain, S. Suri \& D.K. Arora. 1997. Aphrodisiac plants of Aravalli Hills with special reference to safed musli. Pp. 210-223 in Role of Biotechnology in Medicinal and Aromatic Plants. Edited by I. Khan. Ukaz, Hyderabad, India.

Rao, M.R., M.C. Palala \& B.N. Becker. 2004. Medicinal and aromatic plants in agro-forestry systems. Agroforestry Systems 61:107-122.

Rawal, R.S. \& U. Dhar. 1997. Sensitivity of timberline flora in Kumaun Himalaya, India: Conservation implications. Arctic and Alpine Research 29:112-121.

Redenbaugh, K., J. Nichol, M.E. Kossler \& B.D. Paasch. 1984. Encapsulation of somatic embryos for artificial seed production. In Vitro Cellular and Development Biology Plant 20:256-7.

Reyes-Garciaa, V., J.L. Molinac, J. Broeschd, L. Calvete, T. Huancaf, J. Sausc, S. Tannerg, W.R. Leonardh, T.W. McDadeh \& TAPS Bolivian Study Team. 2008. Do the aged and knowledgeable men enjoy more prestige? A test of predictions from the prestige-bias model of cultural transmission. Evolution and Human Behavior 29:275-281.

Rodgers, W.A. \& Panwar, H S.1988. Planning Wildlife Protected Area Network in India. Vol I and II. Wildlife Trust of India, Dehradun India.

Rout, G.R. \& P. Das. 1997. In vitro organogenesis in ginger (Zingiber officinale Rosc.). Journal of Herbs Spices \& Medicinal Plants 4(4):41-51.

Rout, G.R., C. Saxena, S. Samantaray \& P. Das. 1999. Rapid clonal propagation of Plumbago zeylanica Linn. Plant Growth Regulation 28:1-4.

Rout, G.R., S. Samantaray \& P. Das. 2000. In vitro manipulation and propagation of medicinal plants. Biotechnology Advances 18:91-120.

Rout, S.D., T. Panda \& N. Mishra. 2009. Ethno-medicinal plants used to cure different diseases by Tribals of Mayurbhanj District of North Orissa. Ethno-Medicine 3(1):2732.

Sajem, A.L., J. Rout \& M. Nath. 2008. Traditional tribal knowledge and status of some rare and endemic medicinal plants of North Cachar Hills District of Assam, Northeast India. Ethnobotanical Leaflets 12:261-275.

Samant S.S., U. Dhar \& L.M.S. Palni. 1998. Medicinal Plants of Indian Himalaya: Diversity distribution potential values. GB Pant Institute of Himalayan Environment and Development, Almora, India.

Samant S.S., U. Dhar \& R.S. Rawal. 1996. Natural resource use by some natives within Nanda Devi Biosphere Reserve in west Himalaya. Ethnobotany 8:40-50.

Samant S.S., U. Dhar \& R.S. Rawal. 2001. Diversity, rarity, and economic importance of wild edible plants of west Himalaya. Indian Journal of Forestry 24:256-264.

Samant, S.S. \& S.S. Pant. 2006. Diversity, distribution pattern and conservation status of the plants used in liver diseases/ailments in Indian Himalayan Region. Journal of Mountain Science 3(1):28-47.

Samy, R.P., S. Ignacimuthu \& D.P. Raja. 1999. Preliminary screening of ethnomedicinal plants from India. Journal of Ethnopharmacology 66:235-240.

Samy, R.P., M.M. Thwin, P. Gopalakrishnakone \& S. Ignacimuthu. 2008. Ethnobotanical survey of folk plants for the treatment of snakebites in southern part of Tamilnadu. India Journal of Ethnopharmacology 115:302-312.

Sarkar, N., S. Rudra \& S.K. Basu. 1999. Ethnobotany of Bangiriposi, Mayurbhanj, Orissa. Journal of Economic and Taxonomic Botany 23(2):509-514.

Sastry, A.R.K. \& S. Chatterjee. 2000. Prioritisation of medicinal plants of India. Pp. 467-473 in Setting Priorities for Biodiversity Conservation in India. Edited by S. Singh, A.R.K. Sastry, R. Mehta \& V. Uppal. World Wildlife FundIndia, New Delhi.

Savithramma, N., Ch. Sulochana \& K.N. Rao. 2007. Ethnobotanical survey of plants used to treat asthma in Andhra Pradesh, India. Journal of Ethnopharmacology 113:5-61.

Sawangjaroen, N., S. Phongpaichit, S. Subhadhirasakul, S. Visutthi, N. Srisuwan \& N. Thammapalerd. 2006. The anti-amoebic activity of some medicinal plants used by AIDS patients in southern Thailand. Parasitology Research 98:588-592.

Sawangjaroen N., S. Subhadhirasakul, S. Phongpaichit, C. Siripanth, K. Jamjaroen, K. Sawangjaroen. 2005. The in vitro anti-giardial activity of extracts from plants that are used for self-medication by AIDS patients in Southern Thailand. Parasitology Research 95:17-21.

Scartezzini, P. \& E. Speroni. 2000. Review of some plants of Indian traditional medicine with antioxidant activity. Journal of Ethnopharmacology 71:23-43.

Schreider H. \& F. Schreider. 1970. Exploring the Amazon. National Geographic Society. Washington D.C. 


\section{Rai \& Lalramnghinglova - Ethnomedicinal Plants of India with Special Reference to an Indo-Burma Hotspot Region: An overview}

Schultes, R.E. 1967. The place of ethnobotany in ethnopharmacologic search for psychoactive drugs. Pp. 33-57 in Ethnopharmacological Search for Psychoactive Drugs. Edited by D.H. Efron, B. Holmstedt \& N.S. Kline. United States Public Health Service, Publication Number 1645, Washington, D.C.

Shah, N.C. 2007. On the history, botany, distribution, uses and conservation aspects of Nardostachys jatamansi in India. Taxon file, Medicinal Plant Conservation. Newsletter of the Medicinal Plant Specialist Group of the IUCN Species Survival Commission 13:8-11.

Shankar, U. 2003. Aconitum fletcheranum G. Taylor (Ranunculaceae) in eastern Himalaya: Occurrence and conservation. Current Science 84(2):148-151.

Sharma, H.K., L. Chhangte \& A.K. Dolui. 2001. Traditional medicinal plants in Mizoram, India. Fitoterapia 72:146161.

Sharma, P. \& M.V. Rajam. 1995. Genotype, explant and position effects and organogenesis and somatic embryogene sis in eggplant (Solanum melongena L.). Journal of Experimental Botany 46:135-41.

Sharma, P. 1995. Non-wood forest products and integrated mountain development: Observations from Nepal. Non-wood Forest Products 3:157-166.

Sharma, P.K. \& V. Singh. 2006. Ethnobotanical studies in NorthWest and Trans-Himalaya. V. Ethno-veterinary medicinal plants used in Jammu and Kashmir, India. Journal of Ethnopharmacology 27(1-2):989, 63-70.

Sharma, P.P. \& A.M. Mujumdar. 2003. Traditional knowledge on plants from Toranmal Plateau of Maharashtra. Indian Journal of Traditional Knowledge 2:292-296.

Sharma, T.R., B.M. Singh \& R.S. Chauhan. 1994. Production of disease free encapsulated buds of Zingiber officinale Rosc. Plant Cell Reports 13:300-302.

Sheldon, J.W., M.J. Balick \& S.A. Laird. 1997. Medicinal plants: Can utilization and conservation coexist? Advances in Economic Botany 12:1-104.

Short, K.C. \& A.V. Roberts. 1991. Rosa spp (Roses): In vitro culture, micropropagation and production of secondary products. Pp. 376-397 in Biotechnology in Agriculture and Forestry, Volume 15: Medicinal and aromatic plants. III. Edited by Y.P.S. Bajaj. Springer Verlag, Berlin.

Shrestha, T.B. \& R.M. Joshi. 1996. Rare, Endemic and Endangered Plants of Nepal. WWF Nepal Program, Kathmandu.

Singh, A.K., A.S. Raghubanshi \& J.S. Singh. 2002. Medical ethnobotany of the tribals of Sonaghati of Sonbhadra district, Uttar Pradesh, India. Journal of Ethnopharmacology 81:31-41.

Singh, A.K., M. Sharma, R. Varshney, S.S. Agarwal \& K.C. Bansal. 2006a. Plant regeneration from alginate-encapsulated shoot tips of Phyllanthus amarus Schum and Thonn, a medicinally important plant species. In Vitro Cellular and Developmental Biolology - Plant 42:109-113.

Singh, A.K., R. Varshney, M. Sharma, S.S. Agarwal \& K.C. Bansal. 2006b. Regeneration of plants from alginate-encapsulated shoot tips of Withania somnifera (L.) Dunal, a medicinally important plant species. Journal of Plant Physiology 163:220-223.

Singh, D.K. \& P.K. Hajra .1996. Floristic diversity. Pp. 23-38 in Changing Perspectives of Biodiversity Status in the Himalaya. Edited by G.S Gujral \& V. Sharma. British Council Division, New Delhi, India.

Singh, J.S., K.P. Singh \& M. Agrawal. 1991. Environmental degradation of the Obra/Renukoot /Singrauli Area, India and its impact on natural and derived ecosystems. The Environmentalist 11:171-180.

Singh, K.N. \& B. Lal. 2008. Ethnomedicines used against four common ailments by the tribal communities of Lahaul-Spiti in western Himalaya. Journal of Ethnopharmacology 115:147-159.

Singh, S.K., M.K. Rai, P. Asthana, S. Pandey, V.S. Jaiswal \& U. Jaiswal. 2009. Plant regeneration from alginate-encapsulated shoot tips of Spilanthes acmella (L.) Murr., a medicinally important and herbal pesticidal plant species. Acta Physiologiae Plantarum 31:649-53.

Singh, N.P., K.P. Singh \& D.K. Singh. 2002. Flora of Mizoram. Botanical Survey of India. Ministry of Environment and Forest. Government of India, Kolkata.

Sinha, R.K. 1996. Ethnobotany - The renaissance of traditional herbal medicine. Ina Shree Publishers, Jaipur, India.

Srivastava, T.N., B.K. Kapaki \& C.K. Atal. 1987. Ethnomedico-botanical investigations in Sikkim. Journal of Economic and Taxonomic Botany 11: 413-421.

Suri, S.S., S. Jain \& K.G. Ramawat. 1999. Plantlet regeneration and bulbil formation in vitro from leaf and stem explants of Curculigo orchioides, an endangered medicinal plant. Scientia Horticulturae 79:127-134.

Swengel, S.R. \& A.B. Swengel. 1999. Correlations in abundance of grassland songbirds and prairie butterflies. Biological Conservation 90:1-11. 
Takhtajan, A. 1980. Outline of the classification of flowering plants (Magnoliophyta). Botanical Review 46(3):225359.

Upadhaya, K., H.N. Pandey, P.S. Law \& R.S. Tripathi. 2003. Tree diversity in sacred groves of the Jaintia hills in Meghalaya, northeast India. Biodiversity and Conservation 12:583-597.

Upadhyay, R., N. Arumugam \& S.S. Bhojwani. 1989. In vitro propagation of Picrorhiza kurroa Royle Ex. Benth.: An endangered species of medicinal importance. Phytomorphology 39(2,3):235-242.

Valiathan, M.S. 1998. Healing herbs. Current Science 75: 122-1126.

Vavilov, N. 1992. Origin and Geography of Cultivated Plants. Translated by Doris Löve. Cambridge University Press, Cambridge, U.K.

Vavilov, N. 1997. Five Continents. Translated by Doris Löve. International Plant Genetic Resources Institute, Rome.

Ved, D.K., M. Anjana \& D. Shankar. 1998. Regulating export of endangered medicinal plant species - Need for scientific rigour. Current Science 75:341-344.

Ved, D.K., G.A. Kinhal, K. Ravikumar, R.V. Sankar \& K. Haridasan. 2005. Conservation Assessment and Management Prioritisation (CAMP) for wild medicinal plants of North-East India. Newsletter of the Medicinal Plant Specialist Group of the IUCN Species Survival Commission 11:40.

Ved, D.K. \& V. Tandon. 1998. Conservation Assessment and Management Prioritisation CAMP Report for High Altitude Medicinal Plants of Jammu-Kashmir and Himachal Pradesh. Foundation for Revitalisation of Local Health Traditions, Bangalore, India.
Venu, P., V. Kumar \& M.K. Bhasin. 1990. Human activity and its impacts on vegetation: A case study in Sikkim Himalayas. Journal of Human Ecology 1:27-38.

Weekley, C.W. \& T. Race. 2001. The breeding system of Zizyphus celata Judd \& D.W. Hall (Rhamnaceae), a rare, endemic plant of the Lake Wales Ridge, Florida, USA: Implications for recovery. Biological Conservation 100:207213.

WHO. 1992. Traditional Medicine Strategy Report. World Health Organization, Geneva, Switzerland.

WHO. 1995. Global Medium-Term Programme (Traditional Medicine) Covering a Specific Period 1990-1995. World Health Organization Document TRM/MTP/87.1, Geneva, Switzerland.

Wiart, C. 2006. Editor of Ethnopharmacology of Medicinal Plants: Asia and the Pacific. Humana Press, Inc., Totowa, New Jersey.

Wiley, A.S. 2002. Increasing use of prenatal care in Ladakh (India): The roles of ecological and cultural factors. Social Science \& Medicine 55(7):1089-1102.

Yonzone, G.S., D.K.N. Yonzone \& K.K. Tamang. 1984. Medicinal plants of Darjeeling district. Journal of Economic and Taxonomic Botany 5:605-616.

Zaidi, M.A. \& S.A. Crow. 2005. Biologically active traditional medicinal herbs from Balochistan, Pakistan. Journal of Ethnopharmacology 96:331-334.

Zschocke, S., T. Rabe, J.L.S. Taylor, A.K. Jäger \& J. van Staden. 2000. Plant part substitution - A way to conserve endangered medicinal plants? Journal of Ethnopharmacology 71:281-292. 